\title{
A CIRISTIANS APPRECIATION OF OTHER FAITHS
}

REV, GLBERT R RTD, B, D. 

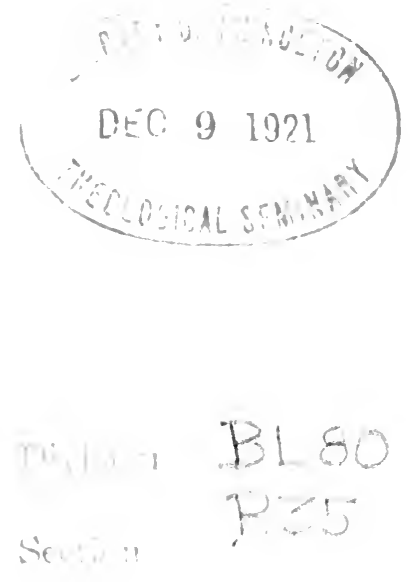



\section{Digitized by the Internet Archive in 2008 with funding from Microsoft Corporation}




\section{A CHRISTIAN'S APPRECIATION OF OTHER FAITHS.}





\title{
A Christian's Appreciation of Other Faiths
}

\section{A Study of the Best in the World's Greatest Religions}

\author{
by \\ REV. GILBERT REID, D. D.
}

Director-in-Chief of the International Institute of China

Author of "Glances at China", "Anti-foreign Disturbances in China", "Religion and Revolution", "China, Captive or Free?"

Chicago - - LONDON

THE OPEN COURT PUBLISHING COMPANY 1921 
Copyright 1921

THE. OPEN COURT PUBIISHING CO. Chicago

IRINTIED IN THE UNITED STATES OF AMERICA ALL. RIGHTS RESERVED 


\section{PREFACE}

This little volume consists of a series of Lectures delivered in Shanghai, China, during the early days of the Great War. They were delivered in the weekly conferences of adherents of the World's Great Religions in the International Institute of China. They were given under the auspices of the Billings Lectureship controlled by the Unitarian Association of Boston. No restriction was placed on the lecturer either in choice of topic or in its treatment. The one selected to give the lectures is an ordained minister in the Presbyterian Church of China, a union organization of all Presbyterians in China.

The appreciative approach to the religious beliefs, opinions and habits of other persons, peoples and races has in later years become more customary than was permissible in earlier days. This is probably the first time that the appreciative attitude has been maintained in an all-around investigation, first of four of the great non-Christian Religions of Asiatic peoples and then of religious conceptions current among Christian peoples. It is hard to say which treatment in these two divisions is harder to maintain, but probably towards those in one's own midst who hold views different from one's own. It is comparatively easier for an American Christian to evince great toleration to a great system like Confucianism, away off in Far Cathay, than to bear with a fellow- 
countryman who holds decided and different views of his own concerning aspects of Christianity.

The great religions discussed are those which are found in China. There is thus a Chinese as well as Oriental tone to the discussion. The hearers of the lectures were those who adhered to different religious Faiths. The appreciative spirit commended itself to non-Christians even more than to Christians, to Chinese more than to Westerners.

Possibly complete truth cannot be reached, if the constructive and appreciative attitude alone is maintained. Perhaps truth requires that criticism be applied to everything which in one's opinion is wrong, erroneous, mistaken or even impolitic. If all this be sound doctrine, then the lecturer must appeal to the large number of critics to complete the study by their varied criticisms, while he remains content with an investigation based on appreciation of what the other man is thinking, of his beliefs, his speculations, his aspirations and his hopes. In general, it is better to think well of another than to think ill, or at least to dwell on another's good points than on his bad points. As a new translator expresses in English the words of St. Paul in 1st Corinthians, Chapter 13, "Love is never glad when others go wrong, love is gladdened by goodness, always slow to expose, always eager to believe the best, always hopeful, always patient".

These lectures were given within the first year of the war, when China was still neutral, had no thought of entering the war, and was more in the calm, judicial, dispassionate, tolerant frame of mind 
towards the opinions of others of whatever kind than Europeans or even Americans. Actual participation in the war inevitably made men's minds biased, as all their information was limited, and the governmental policies were restrictive, prohibitive and in many cases repressive. This is always one of the baneful effects of war. While the Western world, religiously, had grown through several decades more tolerant and liberal, it was suddenly found during the awful developments of the war that, politically, the Western world was very intolerant and illiberal. To religious toleration must be added political toleration, and to this class respect and class co-operation. At present the Chinese surpass Americans in both religious and political toleration,

The discussion in these lectures is not so much from the standpoint of what is commonly called Liberal Religion as in the spirit of appreciativeness. In either case the question arises: "Can missions exist under such circumstances?" If the spirit of missions disappears, then appreciativeness and liberal religion are both wrong and ought to be discarded. This is not the alternative in the estimation of the one who gave the lectures. A special treatment is given to this question as a climax to the study. It deserves serious thought on the part of all who desire the spread of the Kingdom of God.

The lectures are here printed much as they were given in the city of Shanghai, China, in connection with this lectureship. The hope is expressed that a missionary's desire to be appreciative of others and of the beliefs and views of others will lead reli- 
gious thinkers in home lands to cherish the same desire.

The suggestion is thrown out that if appreciation of other Faiths is desirable and productive of good, so appreciation of other nations and peoples-thinking of the good and not the evil-may be the best way to bring about reconciliation, lasting peace and sure friendship. Let us begin to commend, wherever it is possible, and give up the unpleasant, degrading sensations of hate, rancor, and denunciation.

Shanghai, China. GILBERT REID. 


\section{CONTENTS}

\section{PART I.}

Lecture I

Lecture II

Lecture III

Lecture IV

Lecture V

Lecture VI

Lecture VII

Lecture VIII

A Christian's Appreciation of Confucianism.

A Christian's Appreciation of Taoism.

A Christian's Appreciation of Buddhism.

A Christian's Appreciation of Islam.

\section{PART II.}

A Christian's Appreciation of the Jew.

A Protestant's Appreciation of the Church of Rome.

A Trinitarian's Appreciation of the Unitarian.

Appreciation of Jesus Christ by Skepticism,

\section{PART III.}

Lecture IX Concord Among Religions and Unity of the Truth.

Lecture $\mathrm{X}$ An Appreciative Attitude Towards Other Faiths in Its Bearings on Missions.

\section{APPENDIX.}

Lecture I Christianity and the Great War.

Lecture II Religion and the Brotherhood of Nations. 



\section{CHAPTER I}

\section{A CHRISTIAN'S APPRECIATION OF CONFUCIANISM}

The lecture today is under the auspices of the Billings Lectureship of Boston, whose trustees are members of the Unitarian body. I have received appointment to give a series of addresses in China bearing on comparative Religions, but with no restriction as to the themes to be selected or as to the manner of treatment. There has been laid upon me no injunction that I advance views other than my own personal convictions. The appointment comes to me from liberal Christianity in a thoroughly liberal spirit. As Unitarianism does not require of its members and ministers that they subscribe to a creed, so an unusual breadth of mind shows itself in this appointment, that in delivering these addresses I am not compelled to become a Unitarian.

Reciprocating this largeness of spirit, it will be my endeavour, in the different lectures which I may give in different parts of China, to carry out this same broad spirit by a study of concord in Religion as illustrated in the great Religions, particularly those which exist in China.

Being a firm believer in the Christian Religion, especially as personified in Jesus the Christ, I will today venture to present an Appreciation of Con- 
fucianism, with some sympathetic criticisms and suggestions.

From the time I first began to make a study of Confucianism, it has been my growing conviction that no antagonism should exist between Confucianism and Christianity. The two Religions, like two persons, who are friends, differ in mien, physique, temperament, thought, manner, and occupation, so these two Religions, whilst differing in many characteristics, ceremonies, and the consciousness as to what is right and what is wrong, should be friendly to each other and helpful to each other, through agreement in those spiritual ideas which are essential and fundamental, through the reverential realization of the common source of all truth and goodness, and through aspirations after higher things, an enlarged vision, and future perfection, which these Religions, along with the best in all lands, expect ere soon to see fulfilled.

Even where these two Religions differ, they may still dwell together in the spirit of concord. We may not look for uniformity or complete agreement; we may look for harmony and mutual regard. Confucius, in one of his terse sayings, has said: "The Princely Man is harmonious but does not agree with others, the Mean Man tries to be like others, but is not harmonious." It is a misconception to think that Confucianism and Christianity are the same, it is an equal misconception to think that the two are antagonistic. The least that we should pray for is that the two, whilst differing from each other, should be tolerant of each other. The most we can 
pray for is that the two shall at last unite in the unity of God, and in personal determination to do, as Christ enjoined, the will of God.

\section{I.}

The first reason for expressing appreciation of Confucianism is that it lays emphasis on the duties of right living, which are of essential and universal application. The moral nature of men, the rule of conscience, the moral virtues as developed from justice and benevolence, are the foundation principles on which rises the sublime structure of Confucian teaching. The virtues taught under various terms and in manifold forms of expression relate so directly and clearly to the present life, to human obligation, and to actual deeds, that many have assumed that Confucianism is only a system of ethics. If so, we must acknowledge that it is high ethics, and that no people have been so saturated with ethical ideas as have the Chinese. It is the moral element that makes significant the ancient civilization of China.

The soil from which spring forth all virtues is the moral nature of man. The orthodox theory of Confucianism is that all men are thus endowed with this moral nature, a law written in the heart, a conscience to discern between right and wrong, a heavenly rule, the voice of God within. If the orthodox Confucianist and the orthodox Christian differ in their interpretation, it is as to the other theory of what is called "original sin" and "total depravity". That men have an aptitude to sin, and that it is 
hard to get them to do right, will be acknowledged by both Confucianist and Christian, but they separate when they begin to theorize as to whether or not all men are born in Sin and with Sin, and whether sin is hereditary, to be traced back to the first man.

Mencius has spoken most clearly on this particular differing from other theories which prevailed in his day. He said:

"The feeling of commiseration belongs to all men; so does that of shame and dislike; and that of reverence and respect; and that of approving and disapproving. The feeling of commiseration implies the principle of benevolence; that of shame and dislike the principle of righteousness; that of reverence and respect, the principle of propriety; and that of approving and disapproving, the principle of knowledge. Benevolence, righteousness, propriety, and knowledge, are not infused into us from without. We are certainly furnished with them. And a different view is simply from want of reflexion. Hence it is said, "Seek and you will find them. Neglect and you will lose them." Men differ from one another in regard to them;-some as much again as others, some five times as much, and some to an incalculable amount-it is because they cannot carry out fully their natural powers. It is said in the Book of Poetry,

"Heaven in producing mankind, Gave them their various faculties and relations with their law. 
These are the invariable rules of nature for all to hold,

And all love this admirable virtue."

Confucius has said, "The maker of this ode knew indeed the principle of our nature." We may thus see that every faculty and relation must have its law, and since there are invariable rules for all to hold, they consequently love this admirable virtue."

From the quotation which Mencius makes from the Book of Poetry we learn that Confucian teachings are not only ethical, but religious. We are taught that the moral nature of man is the production of Heaven or God. This is the very first sentence in the Doctrine of the Mean, "What Heaven has conferred or ordained is called (moral) nature; to comply with this nature is called the path (of duty) ; to cultivate or put in order this path is called instruction (a system of teaching, a religion)." So the Sung philosopher and commentator, Chu futsze, has declared in this connexion, that "men and the world of matter have each received from Heaven an endowment of supreme law."

Possessed of this moral inheritance from God, all the duties of men are summed up in the one comprehensive word, called Virtue. China's ancient teachers ring the changes on this word; over and over again men are exhorted to cultivate virtue. Sometimes, as in the Great Learning, the injunction is cultivation of one's personality, or what is commonly called the training of character. One of Confucius' maxims is, "The Princely Man cherishes virtue; the Mean Man cherishes comfort." Again he 
says: "When virtue is not cultivated; when learning is not discussed; when righteousness is learned but not practised; and when that which is not good cannot be changed, this is my solicitude." The first sentence in the Great Learning says that "The way of the Great Learning may be summed up in three things: cultivating illustrious virtue, renovating the people and resting in the highest goodness."

Virtue, by which the moral nature of man is denominated, has many characteristics, but summed up in the five cardinal virtues, humanity, righteousness, propriety, knowledge and fidelity. The first two are used the most by both Confucius and Mencius. The first, as a Chinese character, means love as between man and man, and may be called charity or brotherly love. This, too, is characterized in many ways, as is charity in the Christian Scriptures. Thus when Confucius was asked by one of his disciples what it was, he replied: "To be able to practise five things under the heavens constitutes charity." And being asked what they were, he added: "Respect, large-heartedness, fidelity, earnestness, and kindness. If you are respectful, you will not be insulted; if you are large-hearted, you will win all; if you are faithful, men will repose trust in you; if you are earnest, you will accomplish much; if you are kind, you will be able to employ the services of others." This is much like the teaching of the Apostle Paul, when he says: "Put on charity which is the bond or girdle of perfectness."

And as with the great Apostle righteousness is taught equally with brotherly love, so with Confu- 
cius and Mencius. The latter says, "Brotherly love is the heart of man; righteousness is the path for man to follow. How lamentable, if men neglect the path and do not pursue it; if they lose their heart and do not know how to find it again." Confucius says, "The Princely Man in the world does not set his mind either for or against anything, but what is right, that he will follow."

The Chinese Classics are in fact saturated with these teachings, exhortations, commands, for living an upright life and performing all the duties which Heaven prescribes, as revealed in an enlightened conscience, and as applicable to all the conditions of life. The Chinese people, too, have been thus saturated with these high and worthy sentiments, and from childhood, in the school or out of the school, have been impressed with human obligation, as directed in deep reverence to God and in fidelity to man.

\section{II.}

A second reason for appreciating Confucianism is because its great principles, whilst applicable to all life, apply in particular to the social, the political and the educational departments of life. The five cardinal virtues relate to what is called the five social or human relations, ruler and his ministers, husband and wife, parent and child, brother and brother, friend and friend. These relations are, in our Christian phraseology, spiritualized, or widened to far beyond the limits of one's own family circle. Thus the spirit that should exist between parent and 
child, is that which should exist between public officers or rulers and the people.

Similarly, all moral teachings are made to apply to all who exercise authority. The moral science of Confucianism is in the first place social science or sociology, and in the second place, political science or national well-being. The political science of Confucianism gives us light less on forms of government than on the duties of virtue, which rest on officers of the government from the highest to the lowest. In the Confucian sense, political reform means first of all moral reform, the reformation of the individual. Numberless citations could be made, but only a few are needed, and these, I may remark, are known even to the illiterate of China as well as to the learned literati.

The Classic of the Great Learning may be called a hand-book on the science of morals and politics linked together. It deals with the supreme obligations of the Supreme Ruler of a nation, but it is a treatise which each child, rich or poor, all over the land has, in past years at least, been required to memorize. It shows the duty of rulers to train their individual characters, and it shows how closely the prosperity of a nation is linked with the righteous character and conduct of the ruler and officials.

The teaching of the Great Learning by one of the disciples of Confucius corroborates the earlier teachings of the Book of Odes and the Book of History, three to four thousand years ago. In one of the Odes by the Duke of Chou to the Ministers of the Chou dynasty of Shang or Yin, we have the words: 
"Ever think of your ancestor,

Cultivating your virtue,

Always striving to accord with the will (of Heaven).

So shall you be seeking for much happiness.

Before Yin lost the multitudes,

(Its kings) were the assessors of God.

Look to Yin as a beacon;

The great appointment is not easily (preserved).

The appointment is not easily (preserved).

Do not cause your own extinction.

Display and make bright your righteousness and name,

And look at (the fate of) Yin in the light of Heaven.

Have neither sound nor smell.

Take your pattern from king Wen,

And the myriad regions will repose confidence in you."

In another Ode occur these words:

"God said to king Wen,

'I am pleased with your intelligent virtue,

Not loudly proclaimed nor portrayed,

Without extravagance or changeableness,

Without consciousness of effort on your part,

In accordance with the pattern of God.' "

The whole history beginning with the ancient rulers, Yao and Shun, down to Yü the Great, founder of the Hsia dynasty in 2205 B. C., on to Tang, founder of the Shang, in 1776 B. C., on to King Wu, founder of the Chou dynasty, in 1122 B. C., is a his- 
tory full of warning, admonition, and exhortation, with examples of upright reformers and statesmen to follow and cherish, and with the example of bad rulers to shun and abhor. The story is told in the Book of Odes and the Book of History. In the Spring and Autumn Annals Confucius tells of later events, a sad record of disorder, confusion, lawlessness and wickedness, one kingdom quarrelling with another, and one ruler overthrown by another. Everywhere and through all these centuries confirmation is given to the declaration of Solomon, "Righteousness exalteth a nation, but $\sin$ is a reproach to any people."

The Analects, the Great Learning and "Mencius," carry on the same teaching that righteousness and benevolence are the essentials of government. These are the questions which concern the Sages of Confucianism as they expound the science of politics and not the multitude of questions with which Western Political Science loves to enlighten the world.

Ancient learning as distinct from the new learning is also inseparably bound up in the moral and religious principles of Confucianism. Ethics and the substratum of religion enter into a knowledge of history, sociology, finance, political science, belleslettres, poetry, etiquette, and music; whilst modern and western learning has little to say of God, and overlooks the common duties of human relations. I appreciate for this reason what Confucianism has wrought in the past, and dread the effects of the new learning on the student class of today. 


\section{III.}

A third ground of appreciation is the remarkble fact that Confucianism makes supreme and all-important the root origin of things. In looking at Confucianism from the superficial point of view, in its aspects of ceremonialism, rules of etiquette, methods of governing, land taxation, the worship of spirits, and even in its moral maxims, there is good chance for criticism, as well for admiration. When we search for its inner worth, for the kernel of eternal truth, for basic principles, all criticism vanishes and admiration alone remains. This search for first causes, this delving down to the root of the tree of knowledge and tree of righteousness, is the most vital of all the teaching which Confucianism offers to China and also to religious thinkers throughout the world.

Early in the Analects of Confucius occur these words: "The Princely Man gives attention to the root of things; when the root is secure, there springs up all kinds of truth; filial piety and fraternal regard, these are the root of benevolent action."

In the Great Learning we have the simple statement: "All things have root, and they have branches; all deeds have a beginning and an end." The writer then traces back the process of pacifying the Empire to the good order of the State, to the regulation of the family, to the cultivation of the individual, to the rectifying of the heart, to the sincerity of the thoughts, and finally to the highest attainment of knowledge, and this extreme knowledge is found in investigating all things, in the spirit 
of research. He then throws in the sentence that "from the Emperor down to the mass of the people, all should make the cultivation of individual character as the root."

Later on, in the same book, when dealing with the great problem of making the nation prosperous, the writer presents the following stages in the development to the original cause:

"On this account, the ruler will first take pains about his own virtue. Possessing virtue will give him the territory. Possessing the territory will give him its wealth. Possessing the wealth, he will have resources for expenditure.

"Virtue is the root; wealth is the result."

Similarly, the very first sentence in the Doctrine of the Mean, as we have shewn, shews how all religion or instruction is preceded by the path of duty or doctrine, and this by Heaven's law in the soul, or man's moral nature, and this by Heaven or God, from whom every law, principle and religion have come.

In all the Classics we are taught again and again that God is the great First Cause, and on Him we are all dependent. The philosophers of the Sung period revelled in such discussions, but always reverentially, and the Book of Changes with the notes of Confucius forms the basis of their philosophy.

The philosopher, $C h u f u$ tsie, gives an elaborate explanation of the origin of the universe, which is more that of gradual evolution than of distinct creation.

Man, the material world, heaven and earth, are all preceded by a formless, chaotic condition, and 
this in turn is preceded by two principles, the one termed Ruling Principle (li), and the other a Vivifying Principle ( $c h ' i)$. They are two, and yet so joined that the one cannot exist without the other. The one is lifeless; the other full of life. The Ruling Principle needs the Vivifying Principle to secure results, whilst the Vivifying Principle in turn depends on the Ruling Principle for the way its power shall be exerted and exhibited.

Being asked whether the Ruling Principle really existed before heaven and earth, he said: "Before heaven and earth there was most certainly just this Ruling Principle. The Principle existing, heaven and earth existed. If this Principle did not exist, there would have been no heaven or earth, no man or things. The Ruling Principle existing, then the Vivifying Principle exists, flows forth, pervades, and germinates all the material world." Being asked if it was the Ruling Principle which germinated all things, he replied that when the Ruling Principle exists, the Vivifying Principle exists, flows forth, pervades, and germinates. The Ruling Principle as such is without form or body.'

The next problem is the origin of these two Principles. In some respects it looks as if there was nothing beyond or before, but that the two Principles were the finality. This is not, however, the real teaching of this Chinese thinker. He traces them, as well as heaven and earth, to the Absolute, The Great Extreme, T'ai Chi.

He says: "Being asked whether the Absolute is the chaotic mass before heaven and earth came into being, or the general name for the Ruling Principle 
of heaven and all the rational world, he replied that the Absolute is the Ruling Principle of heaven and earth and all things. As to that which is within heaven and earth, the Absolute is in the midst of heaven and earth. As to that which is within all things, the Absolute is inherent in all."

Chu Fu-tsze in his abstract speculation advances to another great thought, and that is that first of all there was the Infinite or $W u C h i$, but that the Infinite was the Absolute, and the Absolute the Infinite, just like a circle in the ancient diagram. The one side is the incomprehensible, the mysterious, the invisible; the other side represents through the Ruling and Vivifying Principles, a vast manifestation, unfolded in heaven and earth, all matter and man. He says: "The Absolute (Great Extreme) derives its name from the idea of the highest pivot. The sages called it the Absolute meaning thereby the root of heaven, earth, and all things. Hence it was that Chou-tsze termed it the Infinite (Wu Chi), and so expressed the Mysterious without sound or fragrance." And again: "The Absolute is just the extreme point, beyond which no one can go; most high, most magnificent, most subtle, most spiritual, surpassing all."

By thus examining the doctrines taught by the Sung philosophers and based on the old, mystical teachings of the Book of Changes, one should be convinced that Confucianism is a religion as well as a system of ethics. Confucianism cannot be limited to the sayings of Confucius, still less to his ethical sayings. The Classics which he compiled are saturated with religious ideas. All righteous conduct 
and a virtuous heart draw their life from above. All are dependent on God.

\section{IV.}

A fourth ground of appreciation is the fact that the men who gave utterance to all these good teachings lived good lives. They practiced righteousness who preached it. They were not only Teachers, but Good Men and Holy Men. From Yao and Shun down to Confucius every one who taught wise and good sayings was an earnest and practical reformer. The lives of these men carried more weight than their words.

In a tribunal age, Confucius was moved to leave his classroom and go out into society and the life of different kingdoms, exhorting the common people, and still more kings and officers, to abandon wickedness and establish just laws and right ideas. As James Freeman Clarke has said: "Many beautiful and noble things are related concerning the character of Confucius, - of his courage in the midst of danger, of his humility in the highest position of honour. His writings and life have given the law to Chinese thought. $\mathrm{He}$ is the patron saint of that great empire.

The seventy-two disciples of Confucius were chosen more for their love of goodness than for mental attainments. Mencius, his chief apostle, is thus reckoned among the Holy Men; his character was as great as his intellect. So, too, the noted commentators of the Tang and Sung periods, and those less known in the last dynasty, have given 
strength to their writings by the sincerity of their lives. Cant, hypocrisy, fine words but bad living, have characterized none of these leaders, but only men of less calibre, and especially the literati of latter years. But as Christianity is not to be judged by the hypocricies of Christians, so Confucianism should not be condemned for the lack of virtue, truth, and sincerity amongst mere students of the ancient Classics. For 4,000 years the noted teachers of thought combined in the Confucian system have been men who practised what they preached, and for this they are worthy of honour.

\section{V.}

A fifth reason for appreciating Confucianism is that it is adapted to the common people as well as to the learned. The usual name of Confucianism implies that it is a Religion of the Learned. To be a Chinese scholar, a thorough knowledge of the Classics has been deemed a necessity. Confucianism is thus not only a system of ethics with spiritual truths, but a method of learning. Chinese education has meant a training in the literary excellences of the Classics, whether the moral and religious ideas were always accepted or not. Thus up to the present the literati have been dependent on the Confucian Classics. Many such are inclined to make Confucianism only a learning, and not a system of ethics. They even go so far as to declare it is not a religion at all. Confucius has been dethroned from his lofty place as a messenger of Heaven and a preacher of righteousness. He has been made only 
an essayist a littérateur. When Confucianism is thus narrowed, it will not be long before, in the face of modern science and the new learning, it is rejected altogether.

As a matter of history, the educated men of China in the past, but not in the present, have been close students of Confucianism. Its ideas have been acceptable, its rites have been observed. The life of the learned has been moulded by Confucianism, which in common phraseology has been called the Great Religion.

The life of the common people has also been moulded by Confucianism. In fact the mind of the Chinese is Confucian. The great underlying, allimportant principles of Confucianism have become known to all, the illiterate as well as the learned. Certain phrases embodying the germ thought of Confucianism are on the lips of ignorant women, the country peasant and the little child. Confucianism should be called not only a Religion of the Learned, but the Religion of China. Its vital teachings clearly expressed have permeated the whole nation. They are adapted to high and low, to ruler and people, and therein show their divine inspiration and origin in Heaven.

These five reasons should convince every one that for a Christian to appreciate Confucianism is not senseless or base but reasonable and sound. The position is both liberal and orthodox.

The one great criticism passed today on Confucianism is that it has no vitality, no dynamic power, and, being a human teaching, can have none. It is true that it seems to be decadent, that its good points 
are being discarded, and that it is fast becoming mere ceremonialism, a worship of Confucius, a cult, and not a life or even a system of religion or ethics. To my mind this is to be regretted. It is equally clear that the criticism contains a fallacy. If Confucianism as a religion has lost its power, it should not be forgotten that many branches of the Christian Church in the past, and also today, have been decadent, retaining the form, but losing the life, of a spiritual religion. The only way for Confucianism or Christianity or any other religion to have life-giving power is to resume connexion with the one living and true God, rely more on His spiritual presence, than on systems and forms, rites and creeds; and believe with a new assurance of faith that God is All and in all, and that man, whilst His offspring, can do no good apart from Him. This truth, as the criticism itself, applies equally to Christian and Confucianist. 


\section{CHAPTER II}

\section{A CHRISTIAN'S APPRECIATION OF TAOISM}

My acquaintance with the teachings, books and followers of Taoism has been nearly as long as my acquaintance with Confucianism, and growth in acquaintance has brought growth in appreciation. On my part there is today more than tolerance of another Faith, there is real sympathetic appreciation.

It is as a Christian and as a missionary that I view with admiration the fundamental characteristics of Taoist doctrine. Just as to my mind there is no antagonism between Christianity and Confucianism, if the essentials be considered, so in the same way Christianity and Taoism are not mutually antagonistic. In very much they are in accord, and in many ways they may be mutually helpful. The Christian teacher, on his part, can find many a choice expression in the Taoist classics, containing high spiritual truths, interpretive of the great teachings of Christianity. The sayings of Confucianism are useful in ethical instruction, and those of Taoism in spiritual instruction.

Both Taoism and Confucianism embrace within themselves the teachings prior to the time of their special founders, Lao tsu and Confucius, just as Christianity includes the records of both the Old and New Testament Scriptures. In ancient times there 
was only one Religion in China, which had been handed down from the earliest days. Confucianism and Taoism were only two branches of the one ancient Faith, two schools of thought interpreting a revelation from God. The Confucian branch represents the more practical and ethical side of religion, whilst the Taoist branch represents the more spiritual and mystical side. There are, indeed, but few references to the ancient Books in Taoist literature, but the careful student will discern many religious ideas which were absorbed into the Taoist Classic from the Holy Men before, just as one who drinks from a stream is drinking from a spring far up the the mountains.

\section{I.}

The student of Taoism must be first impressed with its profound message concerning Tao, the way. This word is best understood if translated as Universal Law, or the Law of Nature, such a law, being the way or course in which Nature operates, or which God, the great first cause, known in Chinese as the Great Extreme, has been operating through the phenomena of the universe. Some have used the word Reason to translate the Chinese term, and thus an impression has been created that Taoists are the Rationalists of China, when more properly they should be called Spiritualists and Mystics.

Another Chinese term called $\mathrm{Li}$, and translated as an Inner Principle, is almost interchangeable with $T a o$, so much so that in colloquial Chinese the two are used together, and are generally understood 
to denote Doctrine or Truth. If there is any sequence in the two terms, Law is preceded by Principle. Thus in the first sentence of the Doctrine of the Mean, written by a spiritually-minded disciple of Confucius, we are taught that first in order comes Heaven or God, who is elsewhere called the Root of all things. Next in order comes the Inner Principle which emanates from God and is implanted in all nature, animate and inanimate; with man this Principle is spoken of as his Moral Nature. From the Inner Principle there comes universal Law or the Way, the particular thought being that God has a way in which this Inner Principle must reveal itself. From this universal Law there issues a Teaching or a Religion, this being the final and specific elaboration of the laws written on the heart by the indwelling Spirit of God.

With the Confucian series Taoism has much in common; its emanations, however, are set forth in simpler order, in a three-fold series. There is first Heaven or God, then this Universal Law, embracing in itself the Inner Principle, and then Virtue or Goodness instead of Teaching or a Religion. The term Teaching, or a religious system, is suited better to the scholastic character of Confucianism, whilst the term Virtue is suited to the Spiritual Character of Taoism. So close is the relation of God to his Law, as it works itself out in the universe and especially in Man, that the impersonal law and the personal God are thought of as one and the same. Hence some have criticised Taoism, as they have criticised modern Confucianism, as being without God, as materialis- 
tic or atheistic. Thus, it is cited, Chu fu-tsu of the Sung dynasty once used the expression: "Heaven is Li or Principle," turning Personality into a mere Idea. The thought of this profound philosopher was rather that even Heaven must conform to the ruling Principles of the universe, and so much so does $\mathrm{He}$ conform thereto that both are brought together as one. In the same way Christ said, "I am the way, the Truth and the Life".

The Taoist Mystic also linked his idea of Law with God and made them one and the same. Lao tsu was a great Monist. God as the Origin of all must conform to the Law which He has implanted in the universe and in Man. Eternal Law binds God as it binds all mankind. Law is universal, it is eternal, it is one, it is God. To such a degree is this true, and so masterful is the sway of Law, that if human thought is to think of a series at all, Law is thought of as first and God as subsequent. Thus in the 4th chapter of the great Classic, it is said that this Universal Law is as if it were the ancestor of the material universe, plainly teaching, as elsewhere it is taught, that before the heavens and the earth and all this material world with its vegetable and animal life there existed this eternal and Universal Law. Then comes the paradoxical statement, "I do not know whose son it is; it seems to be before God'. That is, instead of Law being a son, it is a father, of God. This is, however, only a strong and striking way of saying that Law, by which all the universe is governed, and from which it cannot escape, is everlasting, and so much so is it everlasting, and so supreme, that even God is bound by it, and may be 
said to come after Law. In reality Law and God are alike everlasting.

Chuang tsu, the disciple of Lao tsu, and equally profound in his utterances, advances the same idea as to the priority of this Universal Law. Here are his words :

"This is Law, it has emotion and sincerity, but it does nothing and is without bodily form. It can be transmitted yet not received; it can be apprehended, yet not seen. It is itself the origin and the root (i. e., self-existent). Before there were the heavens and the earth, there it was, securely persisting. By it there came the mysterious existence of the spirits, and the mysterious existence of God. It produced the heavens; it produced the earth. It was before the Great Extreme (or the first cause), yet may not be deemed high. It was beneath the Great Extreme, yet may not be deemed deep. It was before the heavens and the earth were produced, yet may not be deemed of long time. It grew up in highest antiquity, yet may not be deemed old." This is like the Biblical expression, "A thousand years in Thy sight are but as yesterday; from everlasting to everlasting Thou art God."

The first chapter of the Classic of Lao tsu starts off with a most concise statement of Tao or Law, distinguishing two kinds. The one is everlasting, the nameless, the ineffable; the other is not everlasting, and bears a name. From other passages we learn that one is Heaven's Law, and the other Man's Law, but that man to attain to highest Virtue must conform himself, not to his own ideas, but to the Law of God, written on the heart. 
This distinction in the idea of Law, the two aspects of one and the same Law, is that Law has its eternal and God-ward side, full of mystery and limitless, and also appears in Time, is manifested in the phenomena of Nature, and has a Man-ward side, capable of being comprehended, and with definite limits and outward conditions.

Thus the first chapter says: "Law which can be made into laws is not the eternal Law. The Name which can be named ( $i$. e., used on human lips and which is an interpretation of the eternal Law) is not the everlasting Name. The Nameless one is the beginning of the heavens and the earth; the Nameable one is the mother of the material world."

These and other expressions cannot but attract the Christian and should command his appreciation. Though the Tao of Lao tsu has not the same meaning as the Logos of St. John, also translated into Chinese as Tao, yet this two-fold aspect of Tao or Law in the Taoist Classic is like the two-fold aspect of God as taught by the Apostle John. "In the beginning was the Logos, and the Logos was with God, and the Logos was God. All things were made by Him. And the Logos became flesh." Thus God on the one side is mystery, the unknowable; on the other, $\mathrm{He}$ is a manifestation and known. The Logos is God in the aspect of being revealed, culminating in a human incarnation. According to the Taoist idea, Law has these two-fold aspects, both of which, but especially the aspect of manifestation, are concerned in bringing the material universe into being. The Taoist teaching moreover, like that of Confucianism, being based on traditions, is that the world 
was not created, but passed through a process of evolution or emanation. In any case, the fundamental teaching is that the heavens and the earth and all the universe of nature are not everlastin; only Law or God is everlasting. Only Law, only God, is from the beginning, and all else has come therefrom. The cosmogony of Lao tsu does not explain the method of the world's origin; it states the fact without any explanation. Law reveals itself in all the works of nature and in every individual being, and yet it existed before nature and Man came into existence. "It is not merely imminent; it is supernatural and pre-natural."

Another remarkable expression in the Taoist Classic is this one: "Heaven and earth, and all material things, are born from Being and Being is born from Non-Being." In thi sthe idea seems to be, first of all, and which is intelligible, that all materiality comes from immateriality, and the concrete from the abstract. Elsewhere it is said that this universe comes from Universal Law, which continues to abide in all the universe, imparting to all things and all men a particular and distinctive character. From this passage there seems to be implied that this immateriality or this universal Law bears within itself a distinction, called Being and Non-Being, or Existence and Non-Existence. Before this material universe came into shape, there was an unseen, immutable and omnipresent Law, which is like Kant's pure form or Plato's "Ideas", but even this has a higher and lower state, the latter called Being and the former still more intangible and spiritual, denominated as the great Nothing, as pure Non-Being. 
In this highest of all states the last vestige of anything material has disappeared.

Whilst thus distinguished as Being and NonBeing there is only One, called the eternal and Universal Law. Thus in the Confucian philosophy there is the Great Extreme or First Cause and the Absolute or Limitless, but the two are One.

The high spiritual, and deeply mysterious character of Tao or Law is brought out in another remarkable passage:-

"Looking for it, but yet invisible-it may be named Colourless. Listened for, but yet inaudibleit may be named Soundless. Grasping for it, but yet never attained-it may be named Subtle. These three cannot be analysed; they blend and become one. . . . Forever and continuously it remains the Nameless; it is ever reverting into the immaterial. It may be called the Form of the formless, the Image of the Imageless; it may be called, the transcendentally Abstruse."

Here, then, is pure form; here is Spirituality, transcendental and elusive, though the words "spirit" and "breath" as used in the most ancient books are here not used in the Taoist Classic. The whole universe, and even God, become absorbed in the Oneness of an infinite Ideal.

Chuang tsu, the noted disciple of Lao tsu, has also the following reference:

"Tao-Law-is without beginning and without end. Material things are born and die, they are never permanent, but now for better and now for worse, they are ceaselessly changing form."

The difference here described is that between the 
material and the immaterial; the former is temporary or at least had a beginning, the latter is from everlasting to everlasting, without beginning and without end.

This distinction between materiality and immateriality, between the visible resultant and the primaeval, Spiritual cause, or eternal and Universal Law, is the most valuable truth which Taoism unfolds in a great variety of expressions.

To the Christian there is something unsatisfying in the failure to lay the same emphasis on God as on God's Law. Still, there are a few sentences which may be quoted from Chuang tsu. In one place we have these words:

"Human knowledge is limited, and yet by going on to what he does not know, man comes to know what is meant by Heaven or God. He knows him as the Great Mystery; he knows him as the Great Illuminator; he knows him as the Great Equitable; he knows him as the Great Infinite; he knows him as the Great Hope; he knows him as the Great Destiny - this is ultimate knowledge. The Great Unity is everywhere, . . . the Great Destiny is to be depended upon. The ultimate end is God. By conformity comes enlightenment. $\mathrm{He}$ is the revolving centre. He is the beginning."

In another passage this religious philosopher says :

"From of old the comprehension of Law must be preceded by a comprehension of Heaven or God. Then follow all laws and virtues, and after a comprehension of law and virtue (religious and moral 
truth) come the virtues of brotherly love and righteousness."

In summing up this first part of our appreciation, I am inclined to make use of the prologue of St. John's Gospel with a change in one word in English, though the same in Chinese:

"In the beginning was the Law and the Law was with God and the Law was God, the same was in the beginning with God. And without Him was not anything produced that was produced. And the Law was transformed into Nature, animate and inanimate, and we beheld its glory the glory of the highest emanation of God, full of virtue and truth."

Having fully discussed the deep meaning of Tuo or. Universal Law, as unfolded by Taoism more fully than by any other religious system, it is easy to pass on to other features of Taoism which command the Christian's appreciation. These features may be considered less minutely, though their importance must be equally recognized.

\section{II.}

A second reason for appreciating Taoism, particularly from the Christian standpoint, is its teaching concerning Tér or virtue. This word of supreme significance is joined, as it should be, with Tao or Law. The last quotation made under the previous section shews the gradation of thought as understood by Taoist thinkers, namely, God, and then Law, and then complete moral character summed up in the two words Tao and Téh or Law and Virtue. The two ideas, of Law and Virtue, are 
linked together so inseparably that in thinking of the one, we must think of the other.

The Chinese language has no two words in more frequent use than Tao and Téh-Law and Virtueand they are generally combined to mean moral and religious truth and sometimes religion. They represent the spiritual and inner side of religion, while Chiao or Teaching, as used in Confucianism, represents the scholastic or outward side. According to Taoism Virtue is the working and manifestation of Law. Greater than this material world as an Illustration of Law, is Virtue. The term used is a comprehensive one to include all the virtues. The Virtue used with the word Law is viewed as so important that the two together form the title of the great, Taoist Classic. "The appearance of comprehensive Virtue," said Lao tsu, "is none other than conformity to Law. The Character of Law is impalpable and eluding." Law is the root; virtue is the fruitage.

This difference in the order of Law and Virtue appears in another saying found in the great Classic.

"Law germinates, Virtue nourishes. Through the material world they are given form, by the forces of Nature they attain to completion. Therefore amongst all the varieties of the universe nothing should be so revered as Law or so honoured as Virtue. To thus revere Law and honour Virtue does not come through any command, but ever arises spontaneously. Hence the saying that Law germinates, whilst Virtue nourishes, brings up, feeds, brings to completion and maturity, rears and protects. To bring into being, but not to own, to act 
but not to rely on one's action, to raise up but not to dominate: this is called profound Virtue."

Thus the origin of all the various forms of Virtue, as the origin of the material universe, is eternal Law, but Virtue, once produced, goes on for ever both in its task of developing to completion all human character, and in its various operations, from beginning to end, of correct soul-training.

As Tao or Law has within itself a distinctionthe divine and the human, the ineffable and the nameable-so Virtue has a distinction-the superior and the inferior. The great Teacher after expressing this inner distinction goes on to show the relation of Law to all Virtues in the following language:

"In losing Law, Virtue is lost. In losing Virtue, brotherly love is lost. In losing brotherly love, righteousness is lost. In losing righteousness, the sense of propriety is lost." From this we see that every virtuous action must be traced back to eternal Law, summed up in the eternal God.

Nothing is more important, in the Taoist conception, than character saturated with Virtue, which in turn is the truest expression of the voice of God, speaking imperatively in every human soul. Every virtuous characteristic is attainable only through the possession of the essence of Virtue, which is in perfect accord with unchanging Law or the mind of the Infinite. So the Christian Scriptures: "Every good and perfect gift cometh down from the Father of lights with whom there is no variableness, neither shadow of turning." 


\section{III.}

Closely connected with this teaching concerning the supremacy of Virtue is the cognate teaching concerning placidity or passiveness. The teaching is unique, and full of the highest truth and greatest value. There are many references in the Taoist Classic.

Thus, from the Section containing our last citation, there may be taken these lofty conceptions:

"Superior Virtue is Non-Virtue (i. e., does not attempt to be virtuous). Hence it is real Virtue. In. ferior Virtue is bound not to lose Virtue (or does not lose sight of Virtue). Hence it never becomes real Virtue. Superior Virtue is simply non-action, never striving to act. Inferior Virtue is action, again and again striving to act."

In Taoism there is used a word almost as frequently as the words which we translate Law and Virtue. The words means tranquillity, stillness, quiescence. Here is one of the sayings tersely expressed, "Attain to complete abstraction, preserve unalloyed tranquillity." And again: "In return to the root, this is called tranquillity." By this is meant, that a basic element of Virtue is tranquillity.

In another section, the great Teacher says: "I understand the advantages of inaction, $i$. e., non-assertion. Few indeed realize the instruction of silence, and the advantage of inaction."

Still another section imparts instruction so contrary to the usual opinion of men: "In the pursuit of Tao or Law one is willing to decrease, until he reaches a state of non-action. By non-action there 
is nothing but can be done. To win the Empire, one must always be free of much doing. He who is a busy-body can never win the country."

This quality of putting one's self into a state of quietness, but subject to higher influences, is taught again in these words:

"Practice non-action; do the silent deed; have ambition to be without ambition; turn small things into great; make much out of little."

The Sage or Holy Man, according to Taoism, is different from the Confucian conception. Lao tsu says: "The Holy Man abides by non-assertion in his affairs, and practises the lessons of silence."

Chuang tsu, the disciple of Lao tsu, adheres to the same idea, though not emphasized to the same degree. We cite one of his sayings: "What is Tan or Law? There is the Law of Heaven and the Law of Man. Inaction and compliance form the Law of Heaven; action and entanglement the Law of Man. The Law of Heaven is fundamental, the Law of Man is accidental. The distance which separates them is vast. Let us all take heed thereto."

Thus if man conforms to the Law of Heaven, he will aspire after passivity, non-assertion, freedom from useless exertion and troublesome meddlesomeness. He will regard as nothing his own deeds, and give full play to the inner working of the Law of the ages and the Spirit of the Infinite.

By a process of non-action, $i$. e., by not forcing one's self to do a thing, one is able to do most. By striving, one fails to reach the best results-this is the lower form of Virtue. By submitting one's self to the internal operations of Law the greatest results 
are reached-this is the higher form of Virtue. It is by dependence on infinite power, rather than by self-assertion or personal exertion, that Heaven finds scope for carrying out action in the soul.

As with the individual, so with government. The best way to rule a people is by having few enactments and by silent influence that avoids stirring up opposition. Thus Lao tsu says: "The method of universal Law is to work silently and by this method everything is done by and under Law." If kings and rulers could only observe this the whole world could be transformed.

This feature of quietness is a great charm of Taoism. It is like the Biblical expression, "In quietude and in confidence shall be your strength." The true Troist is the opposite of a busy-body. He does not, intermeddle in the affairs of others, but he persuades and enjoins on himself to submit to the true path and the inner law of the perfect One.

Modern Christianity with its institutionalism and many organizations, societies and committees, is rather the converse of such teachings as these of the Chinese mystic, but a choice element in Christianity through all the ages has drawn instinctively to this meditative aspect of spiritual religion, has made use of retreats, and has cultivated self-abasement that "God may be all and in all." In fact the best type of Christian thought and life is in close agreement with this fundamental teaching of Taoism.

IV.

A fourth reason for appreciating Taoism is that it teaches that modesty and reserve are superior 
to ostentation and display. This self-abasement is but an element in placidity and non-action, as they in turn are a form of Virtue. Lao tsu says, "Who tiptoes, totters. Who straddles, stumbles. The selfdisplaying man cannot shine. An egotistic man is not distinguished. One who praises himself has no merit. The self-conceited cannot excel." The idea is that one must hide himself under the cover of Law and Virtue, which are perfect, satisfying, eternal and pervasive. The one who pushes himself forward is apt to diminish the glory and effectiveness of the Supreme and Infinite. This is like the Christian saying, "He that is first shall be last."

One more saying of Lao tsu, very similar to the one already quoted, still further substantiates this truth: "The Holy Man embraces unity and becomes the world's model. $\mathrm{He}$ is not self-displaying and thus he shines. He is not egotistic, and thus he is distinguished. He does not praise himself, and thus he has merit. He is not self-conceited, and thus he excels." These are sentiments closely allied with the sayings of Christ, and we may well say, "They are hard to hear." None the less they are great spiritual truths.

\section{V.}

A fifth teaching which every Christian can appreciate is that it is the weak who are to conquer the strong. One of Lao tsu's sayings is this: "In the world nothing is so delicate and flexible as water, yet for attacking that which is hard and strong, nothing surpasses it. There is nothing that can take 
its place. The weak conquer the strong, the tender conquer the hard. Every one knows this, but no one practises it." This is like the saying of the Apostle Paul, "God chose the weak things of the world that he might put to shame the things that are strong, and the base things of the world, and the things that are despised did God choose, yea, and the things that are not, that he might bring to naught the things that are." This teaching fits in with the two previous ones concerning quietness and self-effacement, non-action and modesty.

\section{VI.}

This exaltation of weakness over all brute force, of the delicate over hardness, fits in with the sixth feature of Taoism, viz., that peace is better than strife. There are several passages illustrating this idea. One is as follows: "He who by the aid of eternal Law assists the ruler of men, does not rely on arms to conquer the world. Where armies are quartered, there briars and thorns grow up. After a great war there comes the year of famine. A good man is determined, and goes no further. He ventures not to take by force."

Again Lao tsu says, "Even beautiful arms cannot make them auspicious weapons. Even inanimate Nature despises them. Hence, he who follows the laws of the universe has nothing to do with them. Soldiers are instruments of ill omen, they are not agents for the Princely Man. Only when it is unavoidable does he use them. What he prizes most is quiet and peace. He will not praise a victory. To 
praise a victory means to rejoice in the slaughter of men." Further on in the same section he adds: "The slayer of multitudes should bitterly weep and lament."

These remarkable, most unusual, well nigh unbelievable, teachings of the great Taoist Teacher stand forth with distinctness, a message to the world as well as to China. The very last sentence in the Taoist Classic sums it all up in these words: "The Law of the Holy Man is to act but not to strive." Whilst elsewhere the idea is one of non-action, the idea here seems to be that whilst non-action is the ideal, yet if one must act, he must not go so far as to strive; or possibly the idea is, that whilst the Holy Mana model to all others-must place himself in a state of passivity, full scope is given to the Law of Heaven to act in and through him, but never to the extent of strife, struggle or warfare.

We seem to hear the words of the ancient Hebrew prophet, as he looked forward to the coming One: "He shall not strive nor cry aloud." We seem to face in another form the gentle, forgiving spirit of Christ-the great Logos appearing in China before He appeared in Judea.

\section{VII.}

A seventh attractive feature of Taoism is that it teaches our duty to be good to all. Thus Lao tsu says, "The good I meet with goodness, the bad I also meet with goodness; goodness is Virtue. The faithful I meet with faithfulness, and the faithless I meet with faithfulness. Faithfulness is Virtue." 
Thus Christ in many ways taught that we should love those that hate as well as those who love, even as God's love goes to the good and the bad alike. Lao tsu in one clause of only four characters says we should "requite hatred with virtue," like the Biblical saying, "Recompense evil with good."

This teaching is the highest form of all human teaching; it brings the Law which governs God into the activities of Man-God's grace and man's love, universal in their scope, without discrimination or partiality.

\section{VIII.}

An eighth attraction is the teaching concerning immortality. There in one sentence in Lao tsu's Classic, viz: "One may die but not perishthis is everlasting life." In many ways Taoism has brought to human hearts a feeling of satisfaction by the hope perpetually taught of life after death, life immortal and life with a spiritualized body.

The Taoist looks forward to the dwelling of the Immortals; the Christian looks forward to eternal life. The Taoist believes that through proper training life becomes perpetual; the Christian realizes that time is only a part of Eternity, and that death is only a passing from a lower form of existence to a higher. Both Taoism and Christianity have the hope of immortality and the thought of a spiritual body of flesh and blood, of animal passions and restricted capabilities. Both are cheered by the belief that in the future life one passes from earth into 
the greater power conditions of God's great universe.

\section{IX.}

The last feature of Taoism which the Christian can appreciate is that he who does right-he who follows Law and possesses Virtue-need fear no harm. "Venemous reptiles do not sting him, fierce beasts do not seize him, birds of prey do not strike him."

Chuang tsu has also words of consolation for the good man, in the face of threatened danger: "The man of perfect virtue cannot be burnt by fire, nor drowned in water, nor hurt by frost or sun, nor torn by wild bird or beast. Happy under prosperous and adverse circumstances alike, cautious as to what he discards and what he accepts-nothing can harm him."

Many passages in the Scriptures, especially in Psalms, have the same lesson of hope and confidence. He who does the will of God has God's protection and need fear no harm. Thus the Psalmist has spoken his message of consolation, which has stayed the souls of martyrs. "There shall no evil befall thee, neither shall any plague come nigh thy tent, for $\mathrm{He}$ shall give $\mathrm{His}$ angels charge over thee, to keep thee in all thy ways. They shall bear thee up in their hands, lest thou dash thy foot against a stone. Thou shalt tread upon the lion and adder; the young lion and the serpent shalt thou trample under feet."

These nine specifications of Taoist teachings cannot but awaken surprise and admiration in the 
thought of the Christian and particularly of the Christian missionary. The Christian should give thanks to God for thus imparting so many truths to the people of China, through all these centuries of the past.

Lao tsu as a person is wrapped in uncertainty, but a benign influence has flowed forth from his life, made articulate in his words, which form a gem in Chinese literature. Whatever be the defects in the followers of Lao tsu, as in the followers of Christ, our admiration goes forth to both Lao tsu and Christ, and we believe in perfect confidence that their goodness, or grace, or truth, or gentleness, all come from God, "to whom be all the glory." 


\section{CHAPTER III}

\section{BUDDHISM, AN APPRECIATION}

It is not our purpose to give a complete exposition of Buddhism, but an appreciation. The courteous, and also the most beneficial, thing to be done by the follower of one religion in reference to another religion is to point out the excellences, not the defects, of the other. This is like looking in the light and at the light, rather than trying to peer into darkness. There is much in Buddhism which a Christian in good reason should heartily appreciate and openly recognize. If Buddhist teachings or practices are bad, it is more becoming to let the Buddhist himself point out what they are.

An unknown writer of a striking book, entitled "The Creed of Buddha," companion of "The Creed of Christ," after referring to current charges against Buddhism, that it is materialistic, atheistic, pessimistic, egotistic and nihilistic, asks, "Can these charges be substantiated? If they can," the writer says, "we are confronted by the most perplexing of all problems. How comes it that a religion which has such vital defects has had such a successful career? That Buddha won to his will the 'deepest heart' of the Far East is undeniable. Was it by preaching the gospel of materialism, of atheism, of pessimism, of egoism, of nihilism, that he achieved this signal triumph? 
To our mind there has plainly been a misconception of Buddhism, but instead of answering one by one these charges, we will adopt the positive and constructive method, and point out one by one those features of Buddhism which impress us as being vital and paramount, and of which the Christian can justifiably express appreciation.

\section{A REFORMING RELIGION}

\section{I.}

Buddhism has always been a reforming religion, just as Christ was a reformer in Judaism, and Huss and Luther and Knox and Cranmer were reformers in the Christian Church under the leadership of the Pope of Rome. Its beginning in India by Sakyamuni was as a reformation in Brahmanism. It was a protest against ceremonialism, the caste system, and excessive asceticism. It attempted to bring the essential ideas of Brahmanism into life. Brahmanism ever since has been different from what it was before. Sakyamuni in his own life represented the reforming spirit. He began his career as a religious devotee by practising asceticism. Finding this unsatisfactory, as being too selfish, he went forth into the busy world and for forty years preached and taught, practised and did good with thought of others more than of self.

Five hundred years later Northern or New Buddhism made its appearance. This is known as the Mahayani branch of Buddhism or the Great Vehicle, with many new elements. The new teacher was Ashvagosha, during the reign of the Mogul Emperor, 
Kanishka. This is the reforming branch that has spread through China and Japan. In its entrance into Japan, it took on other reforming principles, as illustrated in the Pure Land School. Since contact with Christianity, the Buddhism of Japan has taken on other reforming ideas, and it is this branch which is anxious to extend its missionary activities to China. Buddhism is thus far from being an unchanging Faith, but advances with the knowledge of the ages and adapts itself to the varied conditions of men.

\section{PROBLEM OF SUFFERING.}

\section{II.}

Buddhism, whether of the Primitive or Modern School of thought, is conspicuous for its sympathetic realization of human suffering and its purpose to help to transform suffering into happiness and peace. In familiar Chinese phraseology this world is called a world of "the bitter sea," which is to be changed into a world of "Paradise". Buddhism does not attempt to close its eyes to the sorrows, the miseries, the calamities, and the sufferings of this world and of life. Neither does it view them with cold unconcern, or with stern fatalism, but with pity, united with the purpose to give relief and bring about happiness. The Buddha, like the Christ, was touched with the feeling of man's infirmities; he, too, was "acquainted with grief".

A mere kindly reference to human suffering instinctively arouses a response; it is sorrow which 
is the fellow-feeling that unites men together. So, too, the desire for happiness-desire to escape from suffering-is universal. He who presents the possibility of happiness also arouses a response. The very dream of happiness is soothing. Jesus began his first Sermon on the Mount with eight beatitudes. Sakyamuni, too, spoke much of happiness as well as of suffering. Happiness took on its peculiar type from its connexion with suffering. The joy of Buddhism is always "the joy of tears". This gives to happiness an element of tenderness which has strongly appealed to the Oriental mind.

Sakyamuni has many references to suffering. One citation is as follows: "Birth is suffering; old age is suffering; disease is suffering; sorrow and misery are suffering; to be united with loathsome things is suffering; the loss of that which we love and the failure in attaining that which is longed for are suffering; all these things, $O$ brethren, are suffering." Again he speaks very much in Ecclesiastes, "Everything is transient and nothing endures. There is birth and death, growth and decay; there is combination and separation. The glory of the world is like a flower; it stands in full bloom in the morning and fades in the heat of the day."

The message of joy and hope, the Gospel, which Buddha brings, has this refrain: "Ye that suffer from the tribulations of life, ye that have to struggle and endure, ye that yearn for a life of truth, rejoice at the glad tidings. There is balm for the wounded, and there is bread for the hungry. There is water for the thirsty, and there is inexhaustible blessing for the upright." 
These two ideas of suffering and happiness, complementary to each other, are brought out even more effectively in the Mahayana School, to which the Chinese and Japanese are mostly devoted. The most popular object of worship is Kuan Yin, called the Goddess of Mercy, who "saves from suffering and saves from misery", an expression current amongst the people of both nations. So "The Awakening of Faith", the great classic of modern Buddhism, in answer to the question, as to why the book is written, makes this reply, "It is to induce all living beings to leave the path of sorrow and to obtain the highest happiness, rather than to seek the glitter of fame and the wealth of the world." The book closes with this Hymn:

"Deep and wide are Buddhist laws:

These in brief I have declared,

God-ward are eternal stores,

Blessings give to countless worlds."

Instead of Nirvana, suited to the philosophic temperament of India, these other peoples of the Far East look forward to a Paradise in the West or to the Pure Land, where happiness has overcome all sorrow, where purity and blessedness, charity and peace, reign together.

\section{COMPASSION}

\section{III.}

A third ground of appreciation is that which characterizes Buddhism more than anything else, namely, compassion. Brotherly love of fra- 
ternity in Confucianism, is cold. Compassion in Buddhism is warm and moving. The Buddha once said, amongst sayings of the same type, "The charitable man is loved by all. Hard it is to understand. By giving away our food, we get more strength; by bestowing clothing on others, we gain more beauty; by founding abodes of purity and truth, we acquire great treasures."

Again, when the Buddha was visited by one of the Indian kings, who came in his royal equipage, these words of wisdom were spoken: "That which is most needed is a loving heart. Regard your people as an only son. Do not oppress them; do not destroy them; keep in due check every member of your body; forsake unrighteous doctrine and walk in the straight path; do not exalt yourself by trampling upon others. Comfort and befriend the suffering."

Another saying is this: "Hatred does not cease by hatred at any time; hatred ceases by love-this is an old rule." This element, or rather the essence, of Buddhism - this compassion-is specially illustrated in the New Buddhism by the Buddha Amitabha, and by the subordinate divinity Kuan Yin. This latter divinity, or bodishat, has had more of a following than even any of the Buddhas because regarded as the personification of pity to suffering humanity. To one who looks upon the suffering of the world with a heart of compassion, we instinctively yield homage and love, whatever the plan which compassion adopts to show itself forth in escaping from suffering or in removing it.

Thus Buddhism, whether ancient or modern, and whatever its philosophic conceptions, has for cen- 
turies been a power in the Orient because it represents human pity. It is pity rather than philosophy which characterizes Buddhism. Amongst all the religious Teachers of the world, the Christ and the Buddha stand forth as the embodiment of love, which feels for other's woes and yearns to provide deliverance.

\section{SALVATION}

IV.

This idea of deliverance or salvation is the other prevailing power of Buddhism. It is joined with compassion, as compassion is joined with suffering. Compassion has meaning only by its power to save mankind from suffering. To pity without the heart or the power to save soon becomes a mockery and works its own destruction. It is in seeking to save mankind from all forms of misery and sorrow that Buddhism is akin to Christianity, and it is of these three aspects of Buddhism that the Christian must feel appreciation.

Thus the full expression of Kuan Yin is "The Merciful and Compassionate, who saves from suffering and saves from misery." All the Buddhas likewise receive prayer, adoration and trust as being the ones who can effect salvation. The great Buddha in his early life pointed out what lay at the bottom of suffering, namely, desire or passion, craving for more than is right. It may be lust for money, for fame; it may be the indulgence of one's passions; it may be a form of discontent. Therefore, to save men from suffering, they must be saved from pas- 
sion or wrong desire. Buddhism thus goes down to the root of all human trouble.

The Buddha, having stated the forms of suffering, then asks and answers three questions:

1. "What is the origin of suffering? It is lust, passion, and the thirst for existence that yearns for pleasure everywhere, leading to a continual rebirth. It is sensuality, desire, selfishness; all these things are the origin of suffering."

2. "What is the annihilation of suffering? It is the radical and total annihilation of this thirst, the abandonment, the liberation, the deliverance from this passion."

3. "What is the path that leads to the annihilation of suffering? It is the holy eightfold path," and he then proceeds to the enumeration of eight forms of virtue, eight aspects of good character.

In saving men from their passions and so from suffering, Ancient Buddhism and the New Buddhism have provided different methods. According to the former there is an eightfold path of deliverence, summed up in being good-right faith, right resolve, right speech, right action, right living, right effort, right thought, and right meditation.

In the New Buddhism, especially of the Pure Land School of Japan, salvation comes from without, from acove, from one of the Buddhas or one of the Bodishats. One's own efforts are insufficient to bring to an end all the suffering of the world. In Buddhism, as in Christianity, there must be a divine Saviour. Whilst Ancient Buddhism taught salvation by good works the New Buddhism has taught salvation by faith. In both, the predominant note 
is salvation, which issues from the heart of compassion.

\title{
A RIGHTEOUS LIFE
}

\section{$\mathrm{V}$.}

A fifth reason for appreciating Buddhism is the emphasis placed on a righteous life. This is true both in ancient Buddhism and in the New Buddhism, but more particularly in the former, as providing the only way of salvation. The point of interest is that a righteous life means not so much righteous conduct as a righteous soul, righteousness within as essential to righteousness without. In the rightfold path, five of the eight requirements relate to actions of the heart. The righteousness of Buddhism is of the whole man. The teaching is not so much to do right as to be right. "Buddha," as one has written, "lays as much stress on the inward as on the outward side of morality; and he would have us realize that conduct, when divorced from faith and thought and purpose, is worth nothing."

One of the simplest exhortations, understood by all, reads thus:

\author{
"Abstain from all evil, \\ In all things act virtuously, \\ Be pure in mind: \\ This is the religion of the Buddhas."
}

Sakyamuni, in his forty and more years of public preaching, ever exhorting his fellow-men not only to do good but to be good, traced suffering back to evil as he traced it back to wrong desire, and happi- 
ness back to goodness as he had traced it back to the subjugation of all passion, to complete self-control. Thus he said: "If a man speaks or acts with an evil thought, pain follows him as the wheel follows the foot of the ox that draws the carriage." And again: "If a man commits a sin, let him not do it again; let him not delight in sin; pain is the outcome of evil. If a man does what is good, let him do it again; let him delight in it; happiness is the outcome of good."

The exhortations of Buddhism to a life of goodness are without number. They appear in philosophic language, but more often in plain speech to reach all. The distinct aim of Buddhism is to bring about goodness in the world, and so to remove unworthy desires and to be freed from suffering. As deliverance comes from compassion, so a righteous life is summed up in being compassionate. This is the way to remove suffering from the world.

\section{VI.}

A sixth reason for appreciating Buddhism is because of its wise method of building up character, viz., to have only a few positive commandments, but many prohibitions. In the higher stages of development, whether intellectual or spiritual, the negative gives place to the positive, but in all the preliminary stages, the positive is not grasped except by frequent reminders of negative, of the prohibitive, of that to be avoided and shunned. By specifying minutely what one must not do, he learns best what he ought to do. Merely to tell one to be good or just is too indefinite to make an impression 
on the child life of the individual or the nation. To specify a variety of things which are not good and not just, and by a commandment to abstain therefrom, there comes growth in apprehension of goodness and justice. For one to face prohibitions, and to determine what not to do, he learns self-control, and self-control is the strength of all virtue; it is the back-bone of sound character.

The enunciation of great principles, which are to be worked out in each individual in the spirit of perfect freedom, characterizes a high form of civilization. Ordinary society can be governed only by laws. Men need to be told what are the various crimes and misdemeanors, and what is the punishment for breaking this or that law. A child learns how to keep the body strong and healthy only by a few accidents, some pain and much crying. A national catastrophe best awakens a nation to the need of reform. To know what to avoid we best learn what we are to follow. In advanced training we "cease to speak of first principles" and "press on to perfection."

Thus, according to wise educational methods in character-training, Buddhism has first ten commandments, or rather prohibitions, and these are then expanded into several hundreds. The Mosaic law of Ten Commandments, is also negative in form - "Thou shalt not." On the positive side of Buddhism all is summed up in compassion, and, later on, in what is called enlightenment or spiritual knowledge, just as Christianity is summed up in love to God and men, or in being perfect. 


\section{VII.}

A seventh fundamental principle of Buddhism, which every Christian must recognize as true and must accordingly appreciate, is the law of cause and effect applied to morals, or the law of retribution, known in Buddhism as "Karma". One saying known to every man, woman and child in China is this, "Goodness has its recompense; badness has its recompense; goodness and badness in the final reckoning must have their recompense." This law from which no one can escape is a basal principle of Buddhism. It is also a principle of supreme importance inculcated over and over again in Christianity, and whose recognition preserves the Christian from becoming lax and unconcerned. "Whatsoever a man soweth, that shall he also reap." So Christ asked the question, "Do men gather grapes of thorns or figs of thistles?" and then added a scientific law, which all can understand: "A good tree cannot bring forth evil fruit, neither can a corrupt tree bring forth good fruit."

The saying of the Buddha is, "Our good or evil deeds follow us continually like shadows." And again he adds, with encouragement as well as warning, "Since it is impossible to escape the result of our deeds, let us practise good works."

As Christianity gives hope to the sinner, who stands in dread of inevitable consequences, so Buddhism, as we have already shown, makes as much of the principle of salvation as the principle of retribution. There is given the hope of salvation, but even then this law, which runs through the universe, can- 
not be destroyed. It may be altered by higher forces, but not destroyed.

The Buddha, in addressing a king, remarked, "We are enclosed on all sides by the rocks of birth, old age, disease, and death, and only by considering and practising the true law can we escape from this sorrow-piled mountain." There is Karma and there is also escape. According to one school, escape comes through persistency in following the true, the good and the merciful; according to the other and more popular school, escape comes through powers above acting within the soul. Even when one is exhorted to righteousness in order to be saved, he never ceases to look to Buddha for help and mercy. And even when one relies on salvation by the Buddlia, he knows that by no possibility can he escape from Karma, except by transformation of character. Salvation, however it comes, cannot come without a change of heart, of life, overcoming evil and becoming essentially good. This is as much the teaching of Christianity as of Buddhism, and of Buddhism as of Christianity. The law with its hope of alteration runs through all the realms of religious thought.

\section{VIII.}

Buddhism may further be appreciated for the distinction it makes between self and better self, and between lower and higher desires. The desires which lie at the root of all suffering are evil desires, and more properly called lusts or passions. This is indicated in the Chinese term which is used to translate the idea of desire. In the same way a distinc- 
tion prevails in every individual, one who yields to his lower nature and the other who follows his higher nature, the false self, is the servant of passion; the higher nature, the true self, is the servant of conscience. When Buddhism is supposed to teach that self disappears, it is only meant that the lower nature, that which is transitory, and what may be called the animal side of one's nature, or in scriptural language, the flesh, disappears. The higher and spiritual side of one's nature is eternal and is forever developing.

The great Apostle of Christianity mentions, on the one side, his "delight in the law of God after the inner man," and, on the other, he adds: "I see a different law in my members, warring against the law of my mind, and bringing me into captivity under the law of sin which is in my members," and then he cries out in this startling exclamation, "O wretched man that I am! who shall deliver me out of the body of this death?"

These words of the Christian Apostle sound fitting on the lips of the devoted Buddhist. The desire which issues in suffering is this law in one's members, which each one in his sober moments recognizes as base and unsatisfying, contrary to the law in the inner man, which alone satisfies and which in the end shall triumph and last forever. When one succeeds in escaping from self, $i$. $e$., from the desires of this lower self, he is not far from the rest of Nirvana. Whilst escape from these desires of the lower self is effected, it does not mean that all desires are extinguished. Good desires remain and 
have then a chance for full development, in the smooth working of the spiritual faculties.

Sakyamuni, speaking of this lower self, said: "Self is an error; an illusion, a dream. Open your eyes and awake, see things as they are and you will be comforted." And he adds: "Surrender the grasping disposition of your selfishness and you will attain to that sinless calm state of mind which conveys perfect peace, goodness, and wisdom." The desirability of following the true self, higher desires, or what Buddhism calls truth, is seen in these words: "Ye who long for life, know that immortality is hidden in transiency. Ye who wish for happiness without the sting of regret, lead a life of righteousness. Truth is wealth and a life of truth is happiness." Then as Buddhahood is the highest state of truth, it is said: "Buddha is the truth; let Buddha dwell in your hearts. Extinguish in yourselves every desire that antagonizes Buddha, and in the end of your spiritual evolution you will become like Buddha."

\section{IX.}

Along with this important distinction is the other distinction between reality and unreality. It has been supposed that in Buddhism the distinction is between the real and the unreal. The things of life which we see, that which has form, are transient and will disappear, but this does not mean that all of life or all of personality will also disappear. The Nirvana of Primitive Buddhism does not mean nothingness or annihilation, but that the transient ele- 
ments of life have all disappeared and that the highest, the best, the eternal, the spiritual, will remain. The ambition of the Buddhist is to attain to Buddhahood or what is called enlightenment, but enlightenment means spiritual vision, higher than human learning and ordinary knowledge. It is much like wisdom as spoken of in the Bible. To link this highest form of wisdom with annihilation is plainly an absurdity. The annihilation is of the lower form of desire, and of self. The real remains.

According to the Brahmanistic teaching which Sakyamuni accepted, whilst rejecting other teachings there is beneath all phenomena and behind all nature a Universal Soul or Spirit. This alone is permanent; all else is illusory and transitory. The self or Ego which is separate from this Universal Soul is hence illusory and transitory; that which is identified with the Universal Soul is permanent and real. Dr. Charles Cuthbert Hall in his lectures in India, speaking of this primary distinction, says: "The general tendency of Western thinking is to recognize with more or less absoluteness the reality of the phenomenal universe with the countless distinctions of finite souls and finite objects. . . . The immemorial thought of India emphasizes the reality of the Invisible Absolute, whilst to some extent admitting the distinction of the individual soul and its phenomenal environment." This characteristic of Indian thought represents Buddhism in both of its great schools.

Thus we see and hear, the material universe is generally looked upon as existence. Buddhism would then say, if such is existence, we must look for rest 
and perfection in non-existence. What is thought of as existence is illusory and unreal; what is thought of as non-existence is permanent and real. The Universal Soul is of this latter kind. This is Nirvana-a life of pure form, of high spiritual reality. As Mr. Reginald Johnston, in his valuable work on "Buddhist China" says: "This does not mean that Nirvana is another name for blank Nothingness, or that the extinction of the phenomenal ego is equivalent to the annihilation of the real or transcendental self." He quotes from Prof. Noda of Japan who describes Nirvana as "salvation from the misery of the world, as deliverance from suffering, as enlightenment and blessedness."

Dr. Paul Carus in a similar way explains this truth: "And is Nirvana non-existence? Not at all. It is the attainment of the deathless state, of immateriality, of pure form, of eternal verity, of the immutable and enduring, where there is neither birth nor death, neither disease nor old age, neither affliction nor misery, neither tempation nor sin." And he quotes from the Buddhist canon: "When the fire of lust is extinct, that is Nirvana; when the fires of hatred and infatuation are extinct, that is Nirvana; when pride, false belief, and all other passions and torments are extinct, that is Nirvana."

The Christian Apostle, turning away from the sufferings and afflictions of this present world-the unreal part of life-to the reality and bliss of a future life used these words: "Though our outward man is decaying, yet our inward man is renewed day by day . . . for the things which are seen are 
temporal, but the things which are not seen are eternal."

$\mathrm{X}$.

The tenth and last ground for the Christian's appreciation of Buddhism is that it teaches that there are many manifestations of the eternal and omnipresent Spirit or Universal Soul. These are better called theophanies, than incarnations. The many Buddhas, like the prophets of Judaism and Christianity, and the Holy Men of Confucianism, are those who thus manifest God to the world. So much is this so, that in Mongolia Buddha is the term used for God. While the teaching of Buddhism concerning the Absolute and Infinite One is not equal to that in Confucianism, still less to that in Judaism and Christianity, it has this conception of the Infinite One, the Antetype, revealing Himself to mankind in many ways and through many chosen men.

Professor Charles Cuthbert Hall, speaking of Indian religious thought, which also characterizes Buddhism, says: "In its fundamental proposition (i. e., of Christianity) that the Eternal One differentiates His own self-subsisting energy in the infinite variety of finite existences, it is not far removed from the fundamental proposition of the highest Indian thinking, that the self-subsisting Brahma, the Absolute, by his multiplying power, projects the infinite variety of finite existences and distinctions described by the mystic word Maya." He quotes in this connextion from Upton's "Bases of Religious Belief": It follows that there is certain self-revela- 
tion of the Eternal and Infinite One to the finite soul."

The Mahayanist recognition of this thought appears in the great Classic, "The Lotus", where it is said :

"There is but One Great Cause, Enlightening every Sage and Prophet Manifested in the world."

And again :

"All Law comes from one Source Always from the Eternal."

This Source of all which is manifested in Sages and Prophets, Buddhas and Pusas, is in Modern Buddhism spoken of as the Antetype or the True Form, and $\mathrm{He}$ becomes incarnate in the Buddha. "The Soul of the True Form is the great essence of the invisible and visible worlds"; so says "The Awakening of the Faith." Another statement in this Classic is as follows: "As to the work of the True Form, it is that which is in all the Buddhas and the Coming One from that first moment of great love and desire to cultivate their own salvation and then to save others, to the time of their great vow to save all beings throughout all future endless kalpas."

Thus it is seen through these ten elements of Buddhist teachings that Buddhism does not mean materialism, atheism, pessimism, egoism or nihilism. Buddhism in its fundamental ideas has much to be admired and to conserve. It needs a new reformation-the first principle to be appreciated-so that 
the erroneous elements which have crept in may be cast out and the good may be retained. Buddhism needs to have the essence of its principles brought forth into the light, like breaking the nut that we may get the kernel. The nearer we approach to the great founders of the different schools of Buddhistic thought, the more easily does the Christian have feelings of honest appreciation. "Back to Buddha" needs to be said as well as "Back to Christ". 


\section{CHAPTER IV}

\section{A CHRISTIAN'S APPRECIATION OF ISLAM}

It is worthy of reference that this discussion of Islam is under the auspices of the Billings Lectureship, representing the Unitarian body, which of all branches of Christianity is most in sympathy with the great teachings of the Prophet Muhammad. The Unitarian and the Moslem are akin in cardinal religious doctrines. Whilst neither a Moslem nor an Unitarian, the speaker who enters on this study is convinced that every devoted Christian ought to be able, without any undue strain on his conscience, to see and express a hearty appreciation of this Faith which includes Jesus as one of its chosen Prophets.

It is now over thirty years since the speaker first formed the acquaintance of Chinese Muhammadans, in western Shantung, in the two cities of Tsinanfu and Tsiningehow. Many acts of kindness and friendship could ve related, as shewing the attitude of Moslems to Christians in China. Whilst Islam in China, where Arabic is not widely understood, differs in some particulars from the Islam of the land of its birth, in all essentials it is the same; and it is essentials with which we must always deal, if appreciation by an outsider is to be based on sound reason.

Christianity and Islam, the Cross and the Crescent, are the two great competing Religions of the 
world. Being competitive, and alike strong, active and missionary, it is easy for them to become rivals and increasingly antagonistic as they increase in power, in adherents, and in claims to superiority. When brothers become enemies, they are the bitterest of enemies. So the hostility which has been engendered between Protestants and Catholics, between the Christian and the Jew, and the Christian and the Moslem is far more intense than between Christians and the adherents of other Religions such as those already discussed, namely, Confucianism, Taoism and Buddhism. And yet there is more ground for a fraternal than an antagonistic spirit between Islam and Christianity; and so, to do the reasonable thing and cultivate a larger and deeper fraternity, we gladly venture on this discussion, "A Christian's Appreciation of Islam." If the Moslem will reciprocate by expressing appreciation of Christianity, the bonds of union between us will be greatly strengthened.

\section{I.}

The first element in the teachings of the Koran or of Muhammad which the Christian cannot but appreciate is the teaching concerning God or Allah. The many excellent teachings of Taoism are all related to the basic teaching concerning "Tao" or Universal Law. To a much greater degree, all the rules, the laws, the ritual, the rites, and the dogmas enjoined in the Koran are bound up in the cardinal doctrine of the one living and true God.

Whilst "Tao" is all too largely impersonal, Allah is personal, and as a person $\mathrm{He}$ is supreme; $\mathrm{He}$ is 
the Sovereign of the Universe; He is the great I AM, as revealed to the prophet Moses. The follower of Muhammad glories in personality, whilst the philosophies of other Faiths and other peoples are bewildered at the very thought of personality, still more so of an infinite, all-present personality. The God of Islam is pre-eminently a personality, however mysterious the conception; $\mathrm{He}$ is not mere spirit, or a mere influence. Allah never loses His identity in the material universe of which $\mathrm{He}$ is the Creator. Though the word personality is not translatable into Chinese, except as referring to man, yet the idea of a living Ruler, distinct from the world, as taught in the Koran, can be intelligently expressed.

Theology is the science of God. Religion has also been spoken of as man's right attitude to God. If these two definitions be correct, then Islam has as much right to be called a religion and a theology as have Christianity and Judaism, and more so than Buddhism, Taoism or Confucianism, of which we have been able to express appreciation. 'The doctrine concerning God and man's relation to God is cardinal in Islam, and this gives it a distinguished position amongst the religions or theologies of all past time and all peoples. All else is dependent on this one great truth. This of itself is the essence of Islam. All else in Islam might be cast aside, but so long as this truth remains, Islam remains.

The teachings of the Koran concerning the attributes of the Unseen and Infinite Ruler of the universe are very similar to the revelations of the Law and the Prophets, contained in the Hebrew Scrip- 
tures. In these sacred Books the teachings concerning God are the most clear, complete and awe-inspiring of all the sacred Books of the world. The definition in the Westminster Shorter Catechism is regarded as one of the best in all literature. "What is God?" "God is a spirit, infinite, eternal, and unchangable in His being, wisdom, power, holiness, justice, goodness and truth." Such a statement as this suits well as a summary of the Koran's answer to the same question, most vital of all, "What is God?" or still better, "Who is God ?" The last form is the true form of the question in Christianity, Judaism, and Islam, whilst "What is God?" is the natural form of expression in nearly all the other Religions.

According to the Koran, as according to the Hebrew Scriptures, followed, too, by the Christian's New 'Testament, God is the Author or Creator of all Worlds and is its everlasting Ruler. Islam is thus not Deism but pure Theism. $\mathrm{He}$ is also distinct from the material universe, though an ever-present God, and thus Islam is not Pantheism but Theism. Still less does Islam give any countenance to atheism or materialism. Of God the Moslem has no doubts whatever. Having many revelations through prophets, through a Book, and through nature, the Moslem is never an agnostic. In the presence of these denials or misconceptions of God, the Christian can join hands with the Moslem in a strong, unwavering belief in the one living and true God.

In the Christian's treatise of theology we might take the attributes of God, one by one, as there enu- 
merated and proved by Scripture, and prove the same by many citations from the Koran.

The one truth concerning God which stands forth clear and supreme is the Oneness of God. There is no countenance whatever given to polytheism, to tritheism, or to dualism. As in the Hebrew and Christian revelation, God is One. If the Christian doctrine of $\leadsto$ Trinity, or the Buddhist and Taoist Trinities, are rejected as false, it is because they are viewed as teaching three Gods, three Persons, distinct from each other, and here, even the orthodox Trinitarian Christian must acknowledge that if in our thought or phraseology or practice we make unto ourselves three distinct persons, each of whom we call God, we betray ourselves into gross error, subverting that which is fundamental and all-essential, the truth that "the Lord our God is one Lord." As my own father once said, "There cannot be two Gods. One excludes a second." As Joseph Cook, the defender of orthodoxy, once said, "God is one essence or substance. It is the immemorial teaching of religious science that we must not divide the substance of God, and we do this whenever we say that there are in God three persons in the literal, modern, colloquial sense of that word." What is primary, what is essential, to right thinking and right conduct is that there is only one God, who is omnipresent, but always the same one God. This doctrine, we must hold to, whatever be the other doctrines which we fashion in our mind or try to explain to others. The fundamental doctrine of the Oneness of God ought never to be eliminated from our mind or lowered in our thought. To hold to this evermore 
is the faith of Islam and also the faith of Christianity.

The first and second of the Ten Commandments are unequivocal in their meaning, and they are unequivocally accepted by the Moslem. In the language of the Koran it is said: "This is God your Lord. There is no God but $\mathrm{He}$, the Creator of all things. Therefore serve $\mathrm{Him}$, for $\mathrm{He}$ taketh care of all things."

The God taught by Islam is not a tribal God, but the Lord of all worlds or all creations. He is more than the God of Abraham or Israel, He is the God of all men. Thus the first chapter of the Koran, a brief one, a prayer, is as follows:

"Praise be to God, the Lord of the worlds, the most merciful, the king of the day of judgement. Thee do we worship, and of Thee do we beg assistance. Direct us in the right way, in the way of those to whom Thou hast been gracious, not of those against whom Thou art incensed nor of those who go astray."

God according to Islam is All-powerful. In this it agrees with other Religions. In thinking of a Supreme Being, all men think naturally of His. power. $\mathrm{He}$ is sovereign over all. All the events of life are determined by Him. So emphatic is this teaching that an element of Fate is ascribed to the Islamic God. In the same way many passages in the Christian's Bible, taken by themselves, teach not only predestination but fatalism. In both the Bible and the Koran God's sovereignty is exalted and revered. The Koran has these words:

"God: there is no God but He-the living, the self- 
subsisting; neither slumber nor sleep seizeth Him. Whatsoever is in heaven or on earth is His. Who is he that can intercede with Him, except by His good pleasure? He knoweth that which is past, and that which is to come unto them, and they shall not comprehend anything of His knowledge, except so far as $\mathrm{He}$ pleaseth. His throne extended over heaven and earth, and the preservation of both is no burden unto Him. He is the high, the mighty."

As a part of God's omnipotence and omniscience, is the great work of bringing all worlds and all mankind into being. He alone is eternal. The world is His workmanship. He is the author of all, generally described as Creator. In this the Koran and the Bible agree, though neither is so binding as to forbid the Moslem or the Christian to accept the teachings of science. The essential and religious thought is that God had no beginning, and that the material universe came to be through the power of God. The following are some citations from the Koran:-

"He created the sun, moon and stars, and subjected them to law by His behests!"

"The All-mighty, the All-knowing, the All-just, the Lord of the worlds, the Author of the heavens and the earth, the Creator of life and death, in whose hand is dominion and irresistble power, the great, all-powerful Lord of the glorious throne."

"Praise be unto God, who hath created the heavens and the earth, and hath ordained the darkness and the light, those who do not believe in the Lord, make other gods to be His equal. It is $\mathrm{He}$ who hath created you of clay, and then decreed the term of your lives." 
The omnipotence and omniscience of God are, moreover, used for man's good, in the path of holiness, in harmony with righteousness. God is not mere power; $\mathrm{He}$ is not an arbitrary Potentate; $\mathrm{He}$ is just and righteous.

"Dost thou not know that God is almighty? Dost thou not know that unto God belongeth the kingdom of heaven and earth? Neither have ye any protector or helper save God."

The most noticeable teaching of Islam concerning God is that of His mercy. On the walls of the mosque, otherwise totally bare, are the Arabic words which mean, "In the name of God, the Compassionate, the Merciful." These words, too, appear at the beginning of every chapter or Surd of the Koran. God, being full of mercy, can forgive sins and show pity to all who are in trouble. It is for this reason that God is elevated to the highest position not only in men's veneration, but in men's affection. It is because God is gracious and merciful, that men can approach to Him, and have their petitions heard.

"God is the King, the Holy, the Peaceful, the Faithful, the Guardian over all His servants, the Shelterer of the orphan, the Guide of the erring, the Deliverer from every affliction, the Friend of the bereaved, the Consoler of the afflicted; in His hand is good, and $\mathrm{He}$ is the generous Lord, the gracious Hearer, the Near-at-hand, the Compassionate, the Merciful, the very Forgiving."

"Be thou bounteous unto others, as God hath been bounteous unto thee."

What is especially to be commended in Islam is that the teachings concerning God are not so much 
scholastic as practical. Man not only knows God, but has duties towards God. The very word "Islam" means submission to God or peace with God-Atonement. The whole duty of man is to obey God, or, as Christ expressed it, "to do the will of God." It is here that Christianity and Islam meet and can agree. They agree on that which is all-essential, namely, to do God's will, to follow the commands of God. There may be disagreement on many other doctrines, but those who determine to do God's will, not only "will know of the doctrine," as Christ expressed it, but will be performing the central duty of all religions. When one of the scribes asked Jesus, what was "the first commandment of all," Jesus replied, as Muhammad himself in the spirit of his words would reply, "The first commandment is 'Hear, O Israel, the Lord our God is one Lord'," and then from the doctrine of the Oneness of God, he advanced to the doctrine of man's obligation to God: "And thou shalt love the Lord thy God, with all thy heart, and with all thy soul, and with all thy mind, and with all thy strength; this is the first commandment." This, too, is the first commandment of Islam, except that where Jesus used the word "love", Muhammad used the word "obey". With both the same foundation truth of all religions is this: God alone is God, and to Him as supreme, every man has duties of veneration, trust, obedience and love.

This first great teaching of Islam is a truth pertaining not only to Moslems, but to all men, of all nations and creeds. Whether Islam or Christianity be the universal Religion or not, this cardinal truth of Islam is universal; it is the cardinal truth of all 
religions and for all humanity. Whether this or that Religion be universal and absolute, truths such as this proceed from God, lead men back to God, and embrace the whole world and all generations within the limits of their eternal sway.

\section{II.}

Islam in the second place may be appreciated by the Christian because it was a great religious reformation. What Sakyamuni did for Brahmanism, Muhammad did both for Judaism and Christianity. These two Religions in Arabia were dead Religions or had degenerated into idolatry. They had forsaken God. They needed to be awakened by a reformer. It was not so much Protestantism as a Reformation. Islam was more a reform than a protest. Its reform was a return to first principles, as taught both in Judaism and in Christianity. It was especially an appeal to return to God. Like the Hebrew prophets, Muhammad warned the people of their great sin in forgetting the law of God, and in running after strange gods. If he could persuade them to fear God and keep His commandments-to remember the days of old-there was hope for them and for true religion.

As to Christianity as it was represented in Arabia, it was not a clear untarnished Theism, but tri-theism. The Heavenly Father, Mary the mother of God, and Jesus their son, were worshipped as three Gods, and their images appeared in the churches along with the images of other saints. Christianity as taught by Christ had lost its identity in the for- 
malism and errors of the Church of Arabia. Still more the truths proclaimed by God through all the ages had been lost sight of amid the vain imaginings of men's hearts. The only hope was in a return to the great fundamental teaching of all time, that of only One God, an omnipresent spirit, without form or body. The reformation of Muhammad was thus a return to the first and second commandments of the prophet Moses, which Jesus himself had equally taught.

The characters used in Chinese for Islam have this meaning of return. Every Moslem in speaking of his religion is accustomed to speak of the beginnings of things, of God the Creator, of the work of creation, and of Adam the first man. To the Moslem mind the early days of the world were a truer revelation than latter days. In this, Islam agrees with the Hebrew record. Mankind as thus taught, began with monotheism, rather than developed into monotheism. In a religious sense Islam is one of the most conservative religions of the world. By this is meant that the truths on which it is built are those which were handed down from the ancient past and which originated in God. At the same time, whilst not a progressive religion, Islam is a hopeful religion, for other of its teachings bear on the future and on future life.

\section{III.}

A third teaching in Islam which the Christian can appreciate is that God from the beginning of the human race has raised up chosen men, to 
whom $\mathrm{He}$ has imparted special revelations. These men are called prophets. Altogether there have been tens of thousands of prophets, amongst whom there are 313 who are called apostles. These latter are specially endowed and amongst them there arises a still more select group, the highest grade of men, six in all, who became the possessors of a special revelation, and were more holy in character. These six are Adam, Noah, Abraham, Moses, Jesus and Muhammad. Ishmael as the progenitor of the Muhammadan Faith is highly esteemed as one of the chosen of God. Thus worship of the Sages and of ancestors is as strong in Islam as in Confucianism.

Of the five times of worship each day, the first, at dawn, gives reverence to Adam, the ancestor of all mankind; the second, at noon, gives reverence to Ishmael, founder of the Faith; the third in the afternoon, to Elias; the fourth, at sunset, to Jesus; and the fifth, at night, to Muhammad. But above all is God Supreme.

Thus whilst God is a transcendent God, He should not be thought of as separate from the world, but is in fact an immanent God. This immanence of God is seen particularly in this large number of prophets, 224,000 altogether, who are free from all great sins and have special light from God. According to the Christian teaching reverence is also paid to the prophets culminating in Jesus Christ, the greatest of all prophets. Christianity even goes further, recognizing that there is a light which lighteth every one coming into the world.

The doctrine of God's immanence, which has only of late years received special emphasis by Christians, 
is in Islam the doctrine of God's omnipresence. Thus in the Koran occur these words: "Dost thou not perceive that God knoweth whatever is in heaven and earth? There is no private discourse amongst three persons, but $\mathrm{He}$ is fourth of them; nor amongst five, but $\mathrm{He}$ is the sixth; neither amongst a smaller number nor a larger, but $\mathrm{He}$ is with them, wheresoever they be; and He will declare unto them that which they have done, on the day of resurrection, for God knoweth all things." That is, God's omniscience is through God's omnipresence. If God is also a God of mercy as we have seen taught in the Koran, as well as omnipresent, $\mathrm{He}$ will impart of His truth to all the children of men, and those who are most responsive become prophets and apostles.

\section{IV.}

A fourth feature of Islam, which Christians should rejoice in, rather than mourn over, is the high position given to Jesus Christ. Islam is the only religion outside of Christianity which gives special honour to Christ. That it fails to look upon Jesus Christ in the same way as do orthodox Christians is not a matter of surprise. Every doctrine concerning Jesus must be based on historical records. Muhammad and other Arabs, from what they saw of Christians around them, regarded Christianity as tritheism, one of the three Gods being Jesus, son of Mary. Being convinced that this was a great error, Muhammad reverted, as we have already pointed out, to the indispensable and cardinal doctrine of only one God. This doctrine is as essen- 
tial to Christianity as to Islam. There can be no second God, neither must any human being, even a holy prophet, be elevated to the supreme rank of God. If in men's thinking other doctrines and other beliefs subvert this essential doctrine, they must be cast aside that the essential truth of God's Oneness may be preserved.

In understanding the attitude of Islam to Jesus, it must be borne in mind that probably no complete copy of the Gospels, still less of the New Testament as a whole, was in use in Arabia in the sixth century. Muhammad attached special authority to the Pentateuch, to the Psalms, and to the Gospels, but the copy of the Gospels in Arabic was not the same as those on which we base our version. It is supposed that the Gospel in current use in Arabia was one of St. Barnabas. Muhammad's interpretation of Jesus was based on this copy of the Gospels, and this seems to be the source of the reference to Jesus as found in the Koran.

According to the Koran, Jesus was first of all a real human being, "in all points like as we are." $\mathrm{He}$ lived a real human life, though possessed of the special favour and grace of God. Like other prophets, the miraculous entered into his life. He was closer to the Divine than ordinary mortals. He was elevated to the highest position as a religious teacher, or in the language of the learned Pharisee, Nicodemus, "as a prophet sent from God." He stands supreme over Adam, Noah, Abraham and Moses, since he imparts a new revelation to a later age.

According to these same records, Jesus had a miraculous birth. He was, moreover, "the word 
proceeding" from God. He is, spoken of as "honourable in the world to come." "God shall teach him," it is said, "the Scripture, and wisdom, and the law and the gospel and shall appoint him apostle to the children of Israel.' The Koran also relates that he performed many miracles through the power of God; that the Jews attempted to crucify him, but that God rescued him, and carried him away into the heavens; and that he will descend to earth before the resurrection, to overthrow the Anti-Christs and bring peace and love to mankind.

\section{V.}

A fifth reason why Christians can appreciate Islam is because of the importance it attaches to prayer. In Islam, as in Judaism and Christianity, God is a prayer-hearing and prayer-answering God. Muhammad was accustomed to call prayer "the pillar of religion." Hence the Koran enjoins five stated times for prayer during each day. Besides these fixed times one is to be always in a state of prayer. "Be constant at prayer," says the Koran, "for prayer preserveth from crimes and from that which is blameable and the remembrance of God is surely a most sacred duty." And again: "Be constant in prayer, and give alms; and what good ye have sent before for your souls, ye shall find it with God." How like these exhortations of the Koran are the commands of our Bible. "Rejoice evermore; pray without ceasing." And again: "Be ye therefore sober and watch unto prayer. And above all things have fervent charity amongst yourselves." 
Much might be said of the reverence which the Moslem shows to God in his worship, so different from the familiarity, to say nothing of the vulgarity, of some forms of Christian behaviour.

Prayer, moreover, is directed to God alone, in harmony with the cardinal teaching of Islam. God's throne is a throne of grace. Petitions to Him are not in vain. With Him is forgiveness. Prayer is not a form, but a reality and a joy.

\section{VI.}

A sixth reason why a Christian can appreciate Islam is that it teaches the doctrine not only of the immortality of the soul, but of the resurrection of the body. Muhammad, on the basis of the records which he had in his possession, did not teach that Jesus himself was raised from the grave, just as he did not believe that Jesus was actually crucified. In a miraculous manner, however, Jesus was carried away into heaven from which he shall come again. His crucifixion and resurrection require what we may call an historical belief rather than a religious belief or hope. They depend on testimony, on evidence, for belief. A religious belief, a trust, a hope, has to do with the future, and here Islam, like Christianity, teaches the resurrection of all men at the end of the world.

The view given in the Koran of man's resurrection should please those who are inclined to the belief of a bodily resurrection, rather than those who accept the more spiritual view as presented by the Apostle Paul. That Islam accepts the general doc- 
trine, whatever the form of the resurrection, should be pleasing to all branches of Christians.

\section{VII.}

A seventh reason for appreciating Islam is because of its teaching concerning charity, as used in the broad sense of good-will and kindness, and in the narrow sense of alms-giving. Alms like prayer is one of the required practices of the Koran, but behind it lies the feeling of love to all men. "Be good to parents and to kindred and to orphans and to the poor, and to a neighbour, whether kinsman or a newcomer, and to the slaves whom your right hand holds." Another saying is: "Blessed are the patient, the truthful, the lowly, and the charitable, the forbearing who bridle their anger and forgive-God loveth those who do good to others."

In the 16th Sura there is one verse which Muhammad was accustomed to quote at every Friday Service and which many others continue to do. It is this: "Verily God enjoineth justice, the doing of good, and the giving unto kindred, and He forbiddeth immorality, wrong and revolt." Here in brief form is the doing of good to all, to people and to government.

\section{VIII.}

Along with this spirit of charity is that of religious tolerance. Christians have too often condemned Islam as a religion of the sword, when in the relations of Christians and Moslems neither side has much to boast of. The cruelties, harshness, 
hatreds and wars practised by both Christians and Moslems, is contrary to the spirit of the Gospels or the Koran. "Let there be no compulsion in religion," is one of the familiar sayings of the Koran. Another statement is: "Verily those who believe ( $i$.e., the Moslems), and those who are Jews, Christians, or Sabaeans, whoever hath faith in God and the last day, and worketh that which is right and good-for them shall be the reward with their Lord; there will come no fear on them; neither shall they be grieved."

It is only fair to Islam that we as Christians recognize this phase of thought and spirit which characterizes Islam more than the harsh and hard features as lived out by followers of Muhammad like those who have followed Christ. Let us praise this which is the chief thing in Islamic character.

\section{IX.}

A ninth reason for a Christian's appreciation of Islam - and the last one we will emphasizeis its sound attitude towards war. "Peace be with you," is the familiar greeting of the Hebrew, the Oriental Christian and the Moslem. This may be called the greeting of all Oriental peoples.

Islam means submission to God, or in other words, peace with God. When Muhammad was born, the Arabs had frequent bloody feuds; under his teaching the people were unified.

War, accurding to the Koran, is right when it is for self-defence or in behalf of God and the truth. The frequent use of the word "enemies" in the Koran, is the phraseology of war times. One saying is : 
"A sanction is given to those who, because they have suffered outrages, have taken up arms, and verily God is well able to succour them." Another passage reads: "And fight for the cause of God against those who fight against you; but commit not the injustice of attacking them; God loveth not aggressors."

Islam is a religion that teaches the faithful observance of covenants and engagements. Muhammad is thus termed the Faithful. War, if it comes, is in defence of the promised word "O believers," says the Koran, "be faithful to your engagements."

In comparison with the follower of Jesus and of Lao tsze and of Sakyamuni, Muhammad appears as the strong man, and his God as the Mighty God, the Lord of Hosts. The quietness of Jesus and the force of Muhammad are opposite sides of the same truth, Jesus, moreover, was not meek to the point of weakness, and Muhammad was not strong at the expense of gentleness. Many a Saracen in war has shown chivalry towards the enemy, as the Christian has shown a fearless courage.

Here, then, are eight principles or teaching in Islam, which are the superstructure of the one solid foundation of the Oneness of God. There may be difference between the Christian and the Moslem in interpreting these eight points, as of others we have not mentioned, but by building on the same foundation, however different the superstructure, we are at one; the foundation is immovable. To use another figure of speech, we drink at the same fountain, though from different cups. 
The summing-up of Islamic teachings, making sincerity superior to formalism, may be found in these words of the Koran, with which we close: "There is no piety in turning your faces towards the East or towards the West, but he is pious who believes in God and the Last Day, in angels, the Scriptures, and the Prophets, who for the love of God disburseth his wealth to his kindred, and to the orphans, and to the needy, and to the wayfarers, and to those who ask, and for the redemption of captives; who is constant at prayer and giveth alms; and of those who perform their covenants when they have covenanted, and are patient in adversity and hardship and in times of trouble. These are they who are straight. These are they who are pious."

With this from the Koran may be placed the simple statement of the Prophet Micah: "What doth the Lord require of thee, but to do justly and to love mercy and to walk humbly with thy God." 


\section{CHAPTER V}

\section{A CHRISTIAN'S APPRECIATION OF THE JEW}

It is easier for the Christian to appreciate Judaism than to appreciate the Jew. On the other hand, it is probably easier for the Jew to appreciate the Christian than to appreciate Christianity. One of these more difficult tasks-that of the Christian appreciating the Jew-is the theme I have chosen for study in the effort to find concord and to cultivate sympathy between one Religion and another, and between men whose beliefs, tasks and traditions differ more than they agree. The main thought to bear in mind is as to whether these or other differences should stand in the way of a brotherhood of mankind or of a unity in spiritual thought and feeling. These investigations of the different religious Faiths, and the expression of a candid and true appreciation of another's Religion, are all preliminary to the main thought as to how far religious concord is possible in our day or is probable in the future development of the human race.

For a Christian to appreciate the excellence and truths embodied in Confucianism, in Taoism, in Buddhism, and in Islam has been made easy because the personal factor, outside of that of the great founders of these Faiths, has given place to the tenets of these Faiths, especially as taught by their first teachers or as revealed to them through the 
shining of the Light of the World. Were we to eliminate the personal factor in the inter-relationship of Judaism and Christianity, the task, as we have said, would be comparatively an easy one. What is really of practical importance is concord not so much between these two Religions, as between Jews and Christians, who as individuals live in the same society and owe allegiance to the same Governments. Judaism and Christianity may be so represented as to be mutually compatible, but what matters it, if there is no compatibility between Jews and Christians?

This word, compatibility, lies really at the root of the separation between the Jew and the Christian. It is a question of likes and dislikes. The Jew regards the Christian as too often an incompatible person, and the Christian has the same feeling towards the Jew. As the harmonious relationship of Jew and Christian is thus retarded by only a little incompatibility of disposition and personal dislikes, rather than by a divergence of conviction, a disagreement on heavenly revelation, a difference of religious commands, or by a real antagonism as to beliefs, hopes and fears, it would seem that the task of concord is made easy ; but as a matter of fact, incompatibility and dislikes, between whatsoever persons they exist, are often never overcome through a whole life-time, and are only lessened by placing one's self on a higher platform of intellectual approach, or of concentration of thought on vital first principles and things that are essential and therefore which agree. That which is accidentally minor will then be banished through the superior force 
of that which is inherently supreme. The attractiveness of universal principles, the glory of an ideal vision, will act as a mantle to cover the unpleasant appearance of incompatibility.

The Jews as a nation with a Jewish king to reign over them have long since ceased to be. National jealousies, therefore, do not enter into the dislikes felt by Christians towards the Jews.

The fact that Judaism and Christianity whilst originally one Religion, the Religion of the One God, have more and more withdrawn from each other until too often they appear as antagonists, Christianity as the only salvation, and Judaism as the crucifier of the Saviour, this helps to explain somewhat the animosity existing between the adherents of these two Religions now separated from each other. By showing that Christianity has its roots deep set in the soil of Judaism, that Jesus himself was a Jew and not merely of Jewish extraction, that his mission was not to "destroy the prophets", but to "fulfil", and that he, like prophets of old, exhorted all wanderers, all backsliders, all who had gone into by and forbidden paths to the worship of God and the "old way", all this helps to concord between the Jew and the Christian as followers of a particular Religion.

That Jews originally were of the Semitic race, and that most Christians who have persecuted and despised the Jew have been of the different branches of the Aryan race, also helps to explain why the Jew and the Christian do not get along together in amicable and cordial spirit. Racial differences are always so much fire-wood for bringing about a wide- 
spread conflagration. But this racial difference between Jew and Christian is not a barrier. It is only a stumbling block. The distinction of Semite and Aryan is linguistic more than racial. They both belong to the white, Caucasian race; racially they are one rather than two. Even with linguistic differences the Semites have become assimilated into all branches of the Aryans, and the Aryans have become Jews, Russian Jews, German Jews, and Jews of every section of the Teutonic and Slavic peoples. Even the Semitic race at the beginning of the Christian era could not be claimed as of pure and undiluted Semitic blood, for during many centuries the Hebrew had interblended with other peoples. Abraham had Hagar, the Egyptian, as one of his wives, and their offspring was Ishmael, the ancestor of the Moslems; Joseph married the daughter of an Egyptian priest; and Moses the daughter of a Midianitic priest, whilst David was the descendant of the Moabitic Ruth.

The dislikes of feeling by Jew to the Christian and by the Christian to the Jew are thus not so much of race, of religion or of nationality, as because they are different individuals. Not all Christians like each other, as is witnessed in Europe today. Why then, should we be surprised if Jews and Christians do not always like each other? Why should we stumble at their incompatibility?

The difference of personal characteristics in Jew and Christian is due in part to religious training, to social usages, to historic environment, to economic conditions, and to the necessities of trade and barter.

Our mutual dislikes can best be overcome by over- 
looking the characteristics of disposition, conduct and demeanour, and dwelling on the essential worth of the individual man. It is by an intellectual appreciation of each other that our mutual incompatibility will disappear, like the dew of night by the rays of the morning sun. Herein is a duty for both Jew and Christian; but today the olive-branch is extended by one Christian, representing, he hopes, many others, to his Jewish brother.

The Christian does well to appreciate the Jewish people for a common inheritance handed down from the far-away past to Christian and Jew alike. The most vital of all religious truths, of one living and true God, above all and in all, received its highest recognition in the people of Israel who first went out from Ur of the Chaldes and later from Egypt and dwelt west of the Jordan in the land of Canaan. The prophets, priests and kings of the house of Israel were claimed, too, by Jesus and the chosen Twelve. The founders of the Christian Church, Jesus as well as John the Baptist, Paul as well as Peter, James and John, were all Jews, learned the Scriptures, thought of them as the product of divine inspiration, heard the law expounded each Sabbath day in the synagogues, and at stated times worshipped at the temple in Jerusalem. Jesus, at the thought of coming doom to the Holy City, wept over it, and Paul was willing to be accursed if thereby his own people might be saved. The Christians gave proof of their beliefs by citing the law and the 
prophets. They argued more from the revealed word as spoken to these Hebrew saints than by appeal to natural Religion or to the philosophies of Greek and Roman, Persian or Alexandrian. It was the Jew who received the oracles of God and elaborated the Jewish system of rite and ritual, of faith and practice. It was the Jew who gave birth to the Christian's faith and the Christian's hope. It was the Jew who laid the foundations of the Moslem's creed, and who is revered still by all Moslem believers. It is the Jew who unites Judaism, Christianity and Islam. "It was he," says Rabbi Krauskopf, "who laid the foundation to modern civilization. His is the God, his the sacred literature of half the population of the world. The Decalogue, the moral law, the Sabbath, the ethical and social principles of modern society are all his. His the prophets of deathless memory whose gospel was justice, whose doctrine was the might of right, who have served as exemplars to every political and religious and social reformer ever since. His the teaching of the Fatherhood of God. His the teaching of the Universal Brotherhood."

\section{II.}

The Christian should appreciate the life of the Jews as those who have endured suffering, patient in spirit, submissive to God, heroic unto death. From the early days of history down to our own day, no people, no nation, no race, no religion has suffered so much as the Hebrew. They suffered in Egypt, though Egypt's salvation had been wrought 
by Joseph the Jewish premier. They suffered in Persia and Babylonia, beside whose rivers and under whose willow trees they knelt down and wept as they remembered Zion, and yet one of their own race became Esther the Persian Queen and Daniel was first of all the princes over the whole kingdom. They suffered from Roman and Grecian, though they observed the laws, payed their taxes and honoured the king. The days of the Maccabees were days whose heroic story thrills the world. When Jerusalem was at last besieged, bombarded and destroyed, by the Roman legions, the Jews drank full of the bitter cup, and left an example of how women and children as well as men could die for the faith. The Holy Temple and the palace on the heights smouldered into ruins. A million of the besieged gave up their lives, and the remnants of the people, not yet struck down or starved to death, were carried away as slaves or made to fight with wild beasts for the sport of the Pagans of Rome. A triumphal arch, erected to the honour of Titus, was built in Rome and still remains amongst the ruins of that ancient city to tell of the sorrows of the people of Israel more than of the glory of the Roman ruler.

Scattered ever since amongst all nations and dwelling on all continents, the subjects of Christian rulers, their story these nearly 1900 years tells of renewed suffering, of persecution, of outrage, of ostracism, of oppression, not in the excitement of war, but in times of peace, not at pagan or Moslem hands, but at the hands of Christians. Protestants, the Church of Rome, and the Holy Orthodox Church, have alike to give account of the wrongs done to the 
Jews. Only in the nineteenth century has civil liberty been granted the Jews by some nations, whilst other governments, down to the present day, continue their policy of hounding and pogroming the Jew. Russia and Rumania and Austria have in our own generation a long record of Jewish suffering at the hands of Christians.

England and the United States are the two nations where Jews have been blessed with most rights, have had more freedom, and have enjoyed most protection. But the disabilities of the Jews were not removed in England till after the reform introduced for Roman Catholic subjects. It was not until 1858 that a bill passed both Houses of Parliament allowing the same right of conscience for Jew as for a Christian. Whilst thus freed from the acts of persecution in Eastern Europe, the Jews of England and the United States are not in consequence welcomed into Christian homes and Christian society. Mr. Claude Montefiore of London has written thus of the treatment accorded the Jews in these two Anglo-Saxon countries :

"To put the matter briefly, it may be said that the public relations of Liberal Jew and Liberal Christian are most developed and intimate in America, whilst the private relations of Jew and Christian are most cordial and intimate in England. For speaking generally, it may be said that my country, England, is a paradise for the Jew. In England that bad and odious thing known as anti-Semitism, whether it be political or professional or social, whether it depend on religious hatred or race hatred, 
or on pride, or on principle, is practically nonexistent."

\section{III.}

The third feature in the life of the Jews deserving the admiration as well as appreciation of all Christians, is their charity or philanthropy. The very suffering of multitudes of Jews leads the the happy and more-favoured minority to organize Societies of all kinds for the relief of the distressed. Even those who neglect the synagogue have not neglected this primal duty of the Jewish Decalogue: "For the poor shall never cease out of the land; therefore I command thee, saying, Thou shalt open thine hand wide unto thy brother, to thy poor, and to thy needy, in thy land." As in the teachings of the Koran, so in the ancient Jewish Scriptures, Charity or alms-giving is like the Ten Commandments. The tithe is the least that can be done. To do more is better.

In New York City, where there are more Jews than in all Palestine, there are over 1,000 philanthropic societies for the relief of all forms of distress, need and suffering. No question is asked as to whether one is a Polish Jew or a French Jew, an Orthodox Jew or a Reformed Jew; if he is in need, help is rendered. The cries of Jews far away in other lands, whose faces have never been seen, touch a chord of pity, and prompt relief is at once dispatched. The names of Montefiore and de Hirsch are household words in Palestine, in South Africa, and in Argentina, as well as in Russia, Turkey, Morocco, Persia and Rumania. 
One striking statement is made by the New York United Charities Organization that out of 9,000 cases of itinerant beggars only 300 were Jews, and this when one-fifth the population of Manhattan is Jewish.

The evidence of the general character of Jewish generosity is substantiated by countless personal experiences stretching on through the centuries. Whoever has prospered with this world's goods, has attributed his prosperity to the gracious favour of the Lord, and has gladly bestowed of his substance on those less fortunate, less fortunate not because of God's anger but because of men's injustices.

In America we have Mr. Jacob H. Schiff, the successful banker, founder of the Semitic Museum at Harvard University, and active supporter of the Hebrew Loan; Strauss brothers, one of whom, Mr. Isidor Strauss, with his equally devoted wife, went down in the Titanic disaster; Mr. Julius Rosenwald of Chicago, whose business spends $\$ 8,000$ a day in stamps, and whose beneficence goes forth to many causes; Mr. Isaias W. Hellman of San Francisco, who contributed $\$ 100,000$ to the Mount Zion Hospital and is a Regent of the University of California; the late Mr. Joseph Fels, the substantial supporter of single-tax; Mr. James W. Speyer, advocate of universal conciliation; and Mr. Isadore Strauss of Richmond, who left all of his limited fortune for nearly every charity in his city, concerning whom a Christian wrote a pamphlet, entitled "The Benevolent Jew".

Various members of the Sassoon family have made many donations to charitable agencies in Bom- 
bay, the largest amount, 1,000,000 rupees, being to the Royal Institute of Science. Mr. Ellis Kadoorie, through his system of schools for the Chinese, is a name familiar to the people of this country. In fact in India and Hongkong Jews and Parsees rival each other in large-hearted and open-handed helpfulness to their fellow men.

Jewish charity also extends to Christians as well as to Jews. Their donations to hospitals, under no religious control, are almost as frequent as to Jewish Societies. All this in addition to the rule to look after their own poor, just as Moslems and Parsees adhere to the same rule in their own communities.

\section{IV.}

The Christian may also appreciate the Jew for what he has done in defence of his country, whether native or adopted. The Jew is generally reckoned more as a financier than as a warrior. $\mathrm{He}$ probably prefers to trade rather than to fight. And yet the heroism he has exhibited under suffering he is capable of showing on the battle-field. Every country now at war in Europe has its quota of Jewish soldiers. It might seem as if a Jew, being reckoned as outside the pale of Christian communities, and whose entity as a Jew is never forgotten, might be excused from military service and remain a neutral, whilst German and Briton, Frenchman and Russian, Austrian and Hungarian, Turk and Serbian, Belgian and Italian, Pole and Galician, fight out their own wars of conquest or defence, of spoliation or liberation; but in all these countries Jews 
are at the front hearing the call or obeying the order of their King, Emperor, President or Sultan.

In France at the beginning of the present war,* there were as many as eight Jews who were generals and 200 others who were officers of, and above, the grade of captain. In Austria there were six generals, one a lieutenant field-marshal.

In the United States, where there is full liberty and no conscription, and where the Jewish population has mostly come from other countries, the different wars have been represented in full proportion by the Jewish citizens. In the American Revolution, besides the good contingent of enlisted Jews, when the total Jewish population was scarcely 3,000 , the most conspicuous assistance was that of Hayen Salomon, the Philadelphian banker, who, all told, advanced $\$ 200,000$ to the American Government. In the Civil War, on both sides, between 7,000 and 8,000 Jews were enlisted, a larger proportion than of any other religious denomination. Of these nine held rank as generals. Thus the Jews, while loving peace, have performed loyal service in war.

\section{V.}

The Jews have also rendered political service to their country, and for this their fellow-countrymen who are Christians should shew appreciation. Naturally we think of the Earl of Beaconsfield or Benjamin Disraeli, the Prime Minister of Great Britain. He, however, was of Hebrew extraction, but not much of a Jew in his religion. Of the Lord

- This chapter was written in July, 1915. 
Mayors of the City of London five have been Jews. The Lord Chief Justice, one of the most honourable positions in the gift of the Crown, is a Jew, Lord Reading. There are also two members of Mr. Asquith's administration, Mr. Herbert Samuel and Mr. Edwin Montagu.

Italy had a Jewish Premier in 1910, Signor Luzatti, and the present Premier is Jewish on his mother's side.

Dr. Dernberg, once Colonial Secretary in Germany, and still more lately an envoy-at-large to the United States, is the only Jewish name in the German Cabinet, but he, like Disraeli, was not brought up in the faith of his fathers.

Several Jews have been Cabinet Ministers in France. Every Parliament in Europe has had Jewish representatives. In the English Parliament we might mention those who first secured civil rights, as Lord Rothschild and Sir David Salomon, and, later on, Sir Edward Sassoon, Sir Julian Goldsmid, and Sir George Jessel. As to the United States, the late Ambassador to Constantinople, Mr. Oscar Strauss, and the present incumbent, Mr. Henry Morgenthau, are devoted Jews, and also liberal in their sentiments to those of other Faiths.

\section{VI.}

For the services rendered to the world of thought, science and art the Christian should also extend appreciation to the Jew. The Jews, even those of the poor and oppressed classes, have always possessed a traditional passion for learning. As the 
restrictive measures of Governments have stood in way of Jewish participation in public service, so the same restriction has shut out many young Jews from the large Universities. Jews of the conservative school have for centuries been celebrated for their religious lore, their mental acumen and dialectic skill; Jews who have absorbed the secular learning of modern science have also attained to the highest proficiency and been justly esteemed for the good their abilities have brought to mankind, to a world of suffering. In Prussia the percentage of Jewish students in the gymnasium is eight times as large as the percentage of Christian students, and in the German universities seven times as large. In AustriaHungary, there is a similar disproportion. And yet Germany and Austria-Hungary, whilst free from the cruel treatment of Russia and Rumania, have been noted for their anti-Semitic parties and their spirit of narrow intolerance. In the University of Vienna 40 per cent. of the students and 30 per cent. of the professors are Jews. In the intermediate schools of Austria the percentage of Jewish students runs still higher, being as high as 77 per cent.

The intellectual character of the Jewish people comes out in Italy, Spain and Portugal in the middle ages, when through the fierce persecution of the Church they allowed themselves to be absorbed into the Christian communities of these intensely Catholic nations. Through this admixture of Jewish blood, these three nations attained to their highest pre-eminence in culture, commerce and enterprise. It was Jewish capital that enabled Columbus to cross the Atlantic, and the first European to set foot on 
the new continent was a Jew. The Universities at Cordova, Toledo, Barcelona, and Granada were all started under the initiative of learned Jews. On the final expulsion of the Jews from Spain, it has been well said that "the life of Spain went out with the Jews.

Professor Hosmer in "The Story of the Jews" gives the following just praise to the Jews of this and an earlier period: "How great is the debt of civilization to these men (the Jews), whom the Christians so cruelly hounded! They had become a trading race indeed, but not entirely so. They had a large share in the restoration of learning and the cultivation of science in the time of the Renaissance. Through them many Greek writings were translated into Arabic, thence to be rendered into the tongues of Europe, and made accessible to the young universities of the West. Through them medicine was revived, to become the parent of physical science in general. They were universal translators, publishers, and literary correspondents. Their schools at Montpelier in France, Salerno in Italy, and Seville in Spain, abounded in erudite men and scientific experimenters. Whilst superstition reigned elsewhere, they were often comparatively free from it. The deserts of the Hebrews in these respects must never be forgotten."

Many of the Jews, expelled from Spain and Portugal, found a home and a refuge in Holland; and the Dutch received a new vigour which Spaniards and Portuguese had cast aside. Holland to this day has been the land of true liberty. Among the earliest men of genius of Jewish blood was Spinoza, and 
one of the latest, distinguished in International Law, was Tobias Asser.

In the United States, small Jewish communities were established in the British and Dutch Colonies, and with the expanse of the Republic there has come an increased influx of Jews, who at once took on a new life, and laboured hard for modern learning. One half of the students at Columbia University and three-fourths in the College of the City of New York are of Jewish families. The public schools of American cities have more than their due proportion of Jewish boys and girls, and they take more than their share of prizes.

The names of learned Jews form a long list. In medicine they have always ranked high, and then in jurisprudence. Latterly they have turned to journalism, and the editors of leading journals in America and in European countries are found to be Jews. Dr. Ehrlich the discoverer of salvarsan, Dr. Abraham Jacobi of New York, Dr. Cohen of Philadelphia and Sir Feling Semon of London, all great physicians; Professor Klein of Göttingen, Prof. James Sylvester and Dr. Karl Jacobi, famous mathematicians; Darmesteter, the translator of the Avesta into French and English; Mendelssohn-Bartholdy, and Frederic Cowen the composers; Heine, the lyrist; Dr. Stein, the archaeological explorer of Turkistan, and Vambory, the explorer of Central Asia; Brandes, the Danish literary critic; Wertheimer, who devised the kindergarten; Zamenhof, who invented Esperanto; the founders of Reuter's, Woff's and Hirsch's news-agencies; Pulitzer, owner of "The New York World" and founder of the School of 
Journalism at Columbia University; Sarah Bernhardt, the actress; Josef Israels, the leading representative of modern Dutch art; Bergson, the French philosopher, and the first Jew to be elected to the French Academy, and Professor Hermann Cohen the German philosopher; Louis Brandeis the American legal expert on trusts; Waldemar Haffkine, who discovered a method of inoculation for plague; and Bloch, the advocate of disarmament, whose works led to the establishment of the Peace Conference at the Hague at the call of the Czar,-these are some of the great names who have honoured science and culture, and in doing so have honoured Judaism, and blessed the world. Both Nansen and Sven Hedin are grandsons of Jews and owe much to Hebrew as well as to Christian ancestry.

\section{VII.}

There remains one other ground for appreciating the Jew and that is his enterprise in finance and trade. The Jew first lived in tents and was the keeper of sheep and the tiller of the soil. Then, largely through force of circumstances, he became the world's trader and held sway on the Bourse. The mass of the Jews of the world are poor, but they have a persistent faculty for rising in life, give them but the slightest chance. The great department stores of American cities are in the hands of Jews. There are 250 Jewish millionaires in America, a striking contrast to the misery of a Jewish Pale or Ghetto. The Rothschilds of Frankfort, London, Vienna, and Daris; Kuhn, Loeb and Co., Speyer and 
Co. and the Seligman brothers of New York; Lazard Fróres of Paris, London and San Francisco; Stern and Co. of London; the Credit Mobiler of Paris; Baron Bleichröder, who made the transfer of French indemnity to Prussia after the Franco-Prussian war; the Dresden Bank and the Handels-Gesellschaft of Berlin; Sir Ernest Cassel, who financed the Nile Dam; Mr. Paul Warburg, one of five to organize the new banking system of America; anc? the Sassoons of London, Bagdad, India and the Far East; these are some of the great names in the world of finance and equally so in the sphere of philanthopy.

We have finished our review of some of the achievements of the Jews in different walks of life. The recital is sufficient to show with what good reason the Jew should receive the hearty appreciation of the Christian. Strange as the remark may be, if the Christian can appreciate and admire the Jew, it will not be long before he can like the Jew. Compatibility of temperament is best developed on both sides by an interchange of inquiry and instruction and by sentiments of mutual esteem and admiration. To begin by trying to like a person is a futile effort. We may end by liking a person, though we begin with dislikes. The natural process of feelings of concord between two classes of persons like Jews and Christians, different in religion, sometimes in nationality and race, and more often in looks and tastes and habits, is, first to select a few in the other group who can command our respect and arouse a feeling of hero-worship; then advance to a more general view of the other group, whether Christian 
or Jewish, and dwell on its excellences; and finally, when a kind of general admiration is produced, put our love to the test by here and there a personal application. Our like for particular person is thus the outgrowth of a general love of mankind. From the doctrine of the brotherhood of man we expand our affections until the Christian can include $\mathrm{Mr}$. Abraham, Mr. Jacobs, Mr. Israel or Mr. Ezra; and they in turn can include Peter and Paul and John and Mark.

This concord of men, I would add in conclusion, is best acquired by the cultivation of the religious side of man's nature, not by its eradication; by what is called the unity of the spirit. Hence the Christian should not mourn if the Jew is becoming more religious; he should mourn that the Jews are losing their own religion and all religion. Here the Christian can help the Jew, even whilst he remains a Jew. The great task for both Jew and Christian is to lay anew the foundations, and help each other to find God again, until heart and mind, love and trust, are centered in the "one God and Father of all, who is above and through all and in you all." 


\section{CHAPTER VI}

\section{A PROTESTANT'S APPRECIATION OF THE THE CHURCH OF ROME}

It is a striking fact, an interesting circumstance, needing elucidation, that cordial relations between Christians and non-Christians are more feasible sometimes than between Christians and Christians. As shown in the study already made, an appreciation by a Christian of the three great Religions of China, Confucianism, Taoism and Buddhism, frequently denominated as heathen or pagan Faiths, excites but little surprise and is taken to be a conciliatory method of prosecuting Christian missions. Very seldom is there any ill-feeling on the part of the Christian missionary toward the adherents of these three Religions; they may be pitied as dwelling in "heathen darkness", but they are not objects of hate.

When we advanced to a consideration of the relations of the Christian to Islam or to Judaism, the surprising disclosure was made that though Christian, Jew and Moslem all worshipped the one God and were all intellectually monotheistic, yet the records of the past have been stained by unholy wars, generally called holy, by unrighteous hatreds, generally excused as righteous, and by the spirit of bigotry, intolerance and persecution, generally construed as loyalty to the truth. We have found an 
explanation in the common occurrence that hatred between brothers is more fierce and deep-dyed than between different families. In accordance with a modern custom in China, these three brothers have long since divided their inheritance and separated most unpleasantly from each other.

When we advance to the relations between Protestants and Roman Catholics, we are struck by the fact that the closer the relationship, the deeper the hatred. Here is what impresses the non-Christian Asiatic, that those who are Christians, or at least the authorized and ordained priests and pastors of the Christian Church, have nothing to do with each other: yea, that they anathematize, excommunicate and denounce each other. "Are they, or are they not, two branches of the one Holy Catholic Church?" this is the question that puzzles the unbaptized.

Probably one of the best books for confirming the so-called heathen in their false beliefs is a book entitled "Church History", whether as written in a Protestant School or with the imprimatur of the Pope of Rome.

Since Church Reformers in the different countries of Europe withdrew from Papal control or were excommunicated by a Papal Bull, these European nations have laid heavier burdens on "the meek and lowly Jesus", than he received at the hands of either scribe or Pharisee, Jew or Roman. To recount these memories of the past would be no credit to either Protestant or Roman Catholic, and would prove a hindrance to the cause of conciliation as between one Religion and another, between one people and another, or between man and man. Only these awful 
facts of the past may induce us to more strenuous effort in the adoption of wiser methods for the production of international union and inter-religious concord.

Christians of all kinds sailed from Europe to the shores of North America to secure religious liberty. The foundation of the United States of America was one of civil and religious liberty. The Magna Charta of England was to be applied and amplified in the new Republic and independent sovereignty across the Atlantic.

Though full religious liberty is good American law, Americans who carry with them the varied characteristics of the nations from which they come have never up to the present been freed from prejudice, and in some cases animosity, towards one or the other of the two great divisions of Western Furope, the Reformed Church and the Church of Rome. The Anglican or Episcopal Church has acted as a kind of via media between the two, not quite sure whether to call themselves Protestant or Catholic, though determined not to be Roman or Papal.

If we do not misjudge the facts of American life, there has been more opposition by Protestants towards Roman Catholics than by Roman Catholics towards Protestants. As to Roman Catholics, they are so captivated by the breath of freedom in American atmosphere, a contrast to the close air of the Catholic countries from which they come, that they are disinclined to restrict the rights of their Protestant neigbors; but as to Protestants they instinctively feel that the original American Colonies and the present United States have been reserved for 
their exclusive rights, liberty and happiness. Before the days of the War of Independence, the Roman Catholics in Maryland were tolerant of others, though due perhaps to the desire to secure toleration for themselves, whilst the Puritans of New England and the Episcopalians of Virginia believed in religious uniformity but not in religious liberty. The leaders amongst the Protestants for complete toleration were bodies of Christians like the Quakers and Anabaptists in Pennsylvania and Baptists and Quakers in Rhode Island. William Penn and Roger Williams stand forth in early American history as unflinching defenders of freedom of conscience, even though another's conscience should dominate another's life. To the persecuted body of Friends more than to any other was due the insertion of this principle in the fundamental law of many of the colonies, including the Catholic Colony of Lord Baltimore. These are the words of William Penn: "Thus we lay a foundation for after ages to understand their liberty as men and Christians, that they may not be brought into bondage but by their own consent. No person to be called in question or molested for his conscience or for worship according to his conscience."

With the coming of Irish Catholics to America, and, later, of those from southern Europe, there grew up political factions as well as religious denominations opposed to such immigration. The Know Nothing party was typical of this feeling; and both the great Republican and Democratic parties have more than once played to religious prejudices and stirred religious suspicions in order to 
gain votes on local issues. An issue between the Church of Rome and Protestantism has never, most fortunately, been made a national one, so that today the President of the United States is a Presbyterian, whilst the Chief Justice is a Roman Catholic.

Over a hundred and fifty years ago a Judge Dudley of Massachusetts left an endowment for lectures at Harvard University, the third of which, as stated in the will, should be for "The Detecting and Convicting and Exposing the Idolatry of the Romish Church, their Tyranny, Usurpations, Damnable Heresies, Fatal Errors, Abominable Superstitions, and other Crying Wickednesses in their high places; and finally that the Church of Rome is that mystical Babylon, that man of sin, that apostate Church spoken of in the New Testament." It may well be understood that Harvard University of late years has found it hard to comply with such a bequest. It may be taken for granted that here and there some zealous Roman Catholic has also spoken disparagingly of the Protestant sects, all heretics, and doomed to damnation as outside the pale of the true Church, but we doubt if they have been so outspoken, except in countries pre-eminently Roman Catholic. Such characterizations are not deemed political or proper in "free America".

The liberal Congregationalist, President McGiffert, in giving one of these Dudley lectures in 1909, gave utterance to the change for the better which has taken place amongst the people of the States, already reputed to be tolerant and required by law to be religiously liberal. These are his words:

"Many of the animosities of the fathers are no 
longer felt by us; and particularly in religious matters union has taken the place of division, sympathy of hostility, co-operation of rivalry. We are farther away from the days of persecution, and less nervous about many movements and institutions that our fathers dreaded unspeakably. The spirit of toleration has taken hold upon us all, and Protestants can think and speak kindly of men of other faiths, and can co-operate gladly and heartily with them as opportunity offers for the promotion of good ends dear to them all."

To see how far we have advanced in the spirit of brotherliness as between Protestant and Roman Catholic, we need only cite the great Missionary Conference held in Edinburgh in 1910, under the leadership of Dr. John R. Mott, when all mention of missions to Roman Catholic countries was omitted, when a fraternal message was received from a Roman Catholic Bishop, as well as from a Greek Church Bishop, and when the hope was expressed that at the next conference all Branches of the Christian Church might be represented. At that Conference the Rt. Rev. Bishop Brent, who in going to the Phillipines determined to carry on no propaganda among Catholic Christians, gave utterance to these sentiments of unity and fraternity:

"There are four things I want to touch upon. Let us treat the Roman Catholics always as Christians, and let us believe that they are true and sincere Christians until it is proved to us that they are otherwise. In Roman Catholic countries especially let us always preach constructive truth and not destructive truth, and show that we do not intend to 
demolish our neighbors' walls to get stones for our own. In the next place, let us be sure that we get an intelligent grasp of the Roman Catholic faith, polity, and methods before we talk publicly about them, and let us be sure that we do not commit that most grievous of all sins, slandering another Church. Slander is always an evil in any cause, but for one Church to be guilty of slandering another is a double sin in the sight of God."

As an incentive to this unity, I have, amongst other appeals, made application to Cardinal Gibbons and Archbishop Ireland, both of whom I have met in the United States, that they delegate to our conferences of all Religions one of their own men to cooperate with us in the research for spiritual truth.

Ultimate unity between all branches of the Christian Church may never come, but it may be advanced to the stage where disunion, schism and discord will be regarded as a scandal to those who worship the same God and alike follow the teachings of Jesus the Christ. One way to bring this about is for the Protestant to study how and in what respects he may appreciate the Roman Catholics, or, as Bishop Brent has said, have "an intelligent grasp of the Roman Catholic faith, polity and methods."

\section{I.}

The first matter of appreciation is that the Roman Catholic Church, as the Russian or Greek Church, holds with the Protestants to the same cardinal doctrines of Christianity. That there is divergence of belief between these great branches of the 
church must be acknowledged, but in how many essential truths do they all see eye to eye! The points of agreement are explained equally well by Eastern and Western Church, and by the many denominations of the Reformed Faith. Whilst possibly the liberal school of thought amongst Protestants might criticise some of the dogmas and polity of the Church of Rome, the Orthodox bodies have reason for being pleased that in main doctrines there is practical agreement. Protestant and Catholic alike subscribe to the same ancient creeds of the Church, Nicene, Athanasian and Apostles' Creed. The foundation principle, as of Judaism and Islam, and of the primitive faith of all peoples is in the words "I believe in God, the Father Almighty, Maker of heaven and earth." The orthodox teaching of both Protestants and Catholics concerning man is also in substance the same, namely, the sinfulness of man as derived from the fall of the first man, and the need of a divine Saviour to forgive and redeem. All the great branches of the Christian Church likewise teach the divine-human nature of Jesus Christ, or the doctrine of his immaculate conception and the Incarnation. They agree concerning the doctrines of Atonement and Justification, of Christ's crucifixion, resurrection and ascension, of the presence of the Holy Spirit the Comforter, of regeneration and sanctification, of immortality and the resurrection of the dead, of a Day of Judgment and future retribution, of rewards and punishments, of prayer, worship and deeds of penitence in this life and of heavenly bliss in the life beyond. The great Protestant bodies and the Church of Rome 
recognize the authority of the Scriptures and the organism of the Church with its orders and sacraments, all dependent in some way on Christ and the Apostles. In fact Christianity is one Religion, and the groundwork of Calvinistic, Arminian, Lutheran or Anglican theology was laid centuries ago, even before the division of the Eastern and Western Churches.

Christianity, in fact, is one Religion, though the Christian Church be divided. The heresies of the early Church-doctrines of a minority - are heresies of Christendom today, whether Greek Church, Church of Rome, or the Protestant Churches-doctrines still of a minority. In all communions there are both conservative and liberal tendencies; the former are the Orthodox, and of the majority, and they largely agree, whether as seen in the one communion of the other. So, Protestant liberalism and Roman Catholic modernism are essentially the same, though the break with the iron-clad formularies of the past is not always at the same point. It would seem that if any division were to take place in Christianity or the Christian organization, it would be between these conservative and liberal tendencies, as in other religious Faiths, rather than in other matters which separate the Protestant and the Roman Catholic. The conservative Protestant and the conservative Roman Catholic are at one in the great doctrines of Christianity, and for either to appreciate the other ought to be easy, as within the bounds of Christian courtesy and intellectual sympathy. So, too, the liberal Protestant and the liberal Roman 
Catholic should find it possible to work together in the service of humanity.

II.

A second feature of the Church of Rome which every Protestant, and in fact every man, is bound to appreciate is its unparalleled organization. The whole world is mapped out into a complete system. All parts of the system are unified in the Papacy. The Supreme Pontiff is certainly the greatest ruler on the earth, his sway extending into every country, amongst all races, all alike called his children. He is rightly called in Chinese the Emperor of the religion or the Church. From him as Holy Father, the system works out in perfect symmetry and gradation, far surpassing the power and orderliness of the Roman Empire in days of the Caesars, down through the Papal Court, the Cardinals, the Archbishops, Bishops and priests to every humble member of the Church, whatever his colour, class or nationality, going to the same Mass. The Orders of the Church, whether Jesuit or Franciscan, in their way develop to the highest proficiency the organizing ability of the leaders of the Church. Leaving out for the moment the religious or divine aspects of the Church of Rome, it stands forth amongst all human organizations, all forms of government, all societies or associations, as the most complete and compact, the most universal and efficient, organization that the world has ever known. The Holy Father who sits at the Vatican in Rome, whether regarded as Vicar of God or not, commands the hom- 
age of more men clear round the globe than a Caesar or a Constantine, a Charlemagne or a Napoleon, ever dreamed to be his destiny. The whole vast machinery works, moreover, smoothly. There is now and then friction, but this only shows the need of a little oiling; the machine goes on forever. Even when some part of the machinery is taken away, the powerhouse is as mighty as ever; the great wheels move round; and the little wheels have all their places, indicative of the master mind that directs all.

There are differences of opinion; there are even different societies, each with its Father Superior or Mother Superior; but there are no sects in the Church of Rome; sectarianism is swallowed up in the unison of the whole, centered in the sovereign Pontiff at Rome. That which brought about a Protestantism-namely, the Papacy-is that which really gives both unity and strength to the Church of Rome.

Here in China an illustration is afforded of the symmetry of this wonderful Church organization. The whole country is divided into a number of dioceses, and in each diocese some one Society or Order, whether of the Jesuits, Lazarists, Dominicans, or some other, is exclusively at work. This is the perfection of mission comity. The particular Society is seldom named; all that the Chinese through the length and breadth of the land ever hear of is the Religion of the Heavenly Lord-the one Church of Rome.

It is interesting to note that two great organizing minds of the sixteenth century, the one in the Church of Rome, and the other amongst the Church Reform- 
ers, were Loyola, who was founder and first General of the Society of Jesus, and Calvin, who drew up the Ordinances for a Puritan State in Geneva, both fellow students in Paris, both under ecclesiastical trial during the same years, and both organizing new organizations within the Church in the same year, 1541.

Not merely the admirers of Presbyterianism, of Methodism, whose distinct characteristic was method, of Episcopacy with the primacy of the Archbishop of Canterbury, and of the Lutheran Churches on the Continent, can readily see the attraction of the Roman organization, but all who belong to more independent bodies and believe in individualism, must also acknowledge that no religion and no nation has ever produced such a complete and all-embracing system of government as that which through the centuries has been unfolded in the Church of Rome. As one has well said: "The realm over which Augustus Caesar swayed his sceptre was narrow compared with that of his spiritual successor. The encyclical letter which emanates from the Quirinal Palace is addressed to one half the civilized world, and binds the consciences of a fourth of the human race."

\section{III.}

A third reason why every Protestant should appreciate the Church of Rome is its high ideal concerning the Church of God. What has already been said of the Church of Rome as a great organization concerns aspects human and practical. What is now to be explained concerns divine and idealistic ele- 
ments. We now deal not so much with the Church of Rome as with the Roman conception of what is called in the early creeds "the Holy Catholic Church."

According to ideas largely prevalent amongst Roman Catholic thinkers, the beginnings of Christianity were centered in the establishment on earth of the Kingdom of God or Heaven. To the Jews this thought imparted enthusiasm and hope, as being the larger realization not only of the Church of God centered on Mount Zion, but of the longings and desires through many centuries that a Messiah would come to re-establish a Kingdom of God's chosen people.

The message, "The Kingdom of Heaven is at hand" was a germinal thought in the mind of Jesus and of his disciples. In due time the word "Church" supplanted the word "Kingdom", but the thought remained the same. That which existed in heaven was some time to exist over all the earth-allegiance to God as Sovereign and to Jesus Christ His Vicegerent on earth. That which previously existed amongst the people of Israel was now to exist amongst the true Israel, who followed Christ, namely, a society of God's elect, with Jesus as its head. The power first held by Jesus alone was transmitted to the Apostles, and through them to the Church at large and to the bishops in charge of the souls of men. The Church was the body of the risen Lord; and His divine nature passed over to the Church down to the end of time. There was only "one faith, one hope, one baptism;" there was only one Saviour, one religion, one Church. Whilst the adherents of 
other Faiths have been accustomed to use the word "Religion", and seldom the word "Church", the Christians have almost exclusively used the word "Church", and but seldom the word "Religion". This is seen in China when only within the last few years have Confucianists, Buddhists and Taoists organized themselves into Societies, using the same term as Christians use for the Church. Amongst Protestants, on the other hand, the term Christian Religion has taken the place of the Christian Church. Amongst Roman Catholics the Church is supreme, that which was organized by Christ to carry forth His truth.

The early Church was one, though there were many local churches. It was not long before the Bishop of Rome was recognized as successor of St. Peter, as vicar of God, as Vicegerent of Christ. Even when this primacy was not accepted, there was no doubt concerning the oneness, the sacredness, the divine character, of the Christian Church. Neither was the Church divided into the visible and invisible: the Church was one, with both visible and invisible, external and internal, characteristics.

It was generally believed that the Church was the living embodiment of Christ. This elevated the Church as a divine organism far above all organizations of human device and human control. Of this there was but little doubt; such dispute as there was, and has continued to be, centred around the degree of power and authority which rested in the Bishop of Rome, later designated as the Pope, and with the great œcumenical Councils. The Church of Rome, beyond these particular matters of dispute, has with 
other Christians laid great stress on the grandeur and significance of the Church idea. All the Eastern Churches and most of the Anglicans, Lutherans and Presbyterians, amongst the Protestants, have been influenced by the same ideal, not of ecclesiasticism but of God's Kingdom as represented in the Christian Church. To the Roman Catholic this ideal may be blurred by the other thought that only the Church of Rome is the Kingdom of God and that all others, whilst equally Christian, have withdrawn from the Church and are guilty of schism; but this shadow on the light should not lessen our reverence for the light itself.

"The genius of Catholicism is union and co-operation, a common purpose and common labour for its accomplishment." This unity is the essence of Catholicism, though not always of Romanism. This unity, this Catholicity, is none the less a dominant note in the teachings of the Church of Rome.

In the Roman conception of the Church there is also the thought of historical continuity, the Church of today being traced back to Christ who is "the Head over all things to the Church." In the Church the Christian of today is linked with all the saints who have gone before. "The communion of saints" is inseparably joined with a belief in "the holy Catholic Church." In comparison, Protestantism appears as isolation, but even for the one who loves isolation it ought not to be hard to see the attraction of the Roman Catholic conception and to express appreciation.

It is this high idealism, characterizing the Church of Christ, this sacredness, unity, catholicity and con- 
tinuity, which keeps the Modernist movement from leaving the Church of Rome and joining with the liberal element in Protestant Churches. This fact makes clear the reasonableness of the Church of Rome concerning the inner life, the soul, of the Kingdom which Christ inaugurated and of the Universal Church which $\mathrm{He}$ came to found.

\section{IV.}

A fourth attractive feature of the Church of Rome is the repose which it offers for doubt and uncertainty in the acceptance of the Church's authority. John Henry Newman is not the only one who has journeyed to the Church of Rome that he might thereby find peace of mind. As Professor William Adams Brown has said, "The joy which sings in the closing chapter of his Apologia is not the satisfaction which comes from insight into truth, but the peace which follows the relinquishment of a hopeless quest."

Every one to find peace in his intellectual speculations, in his strivings after truth, in his bewilder. ment over clashing theories and varied teachers, must at last fall back on what to him is taken as authority. One grows weary of searching; he is satisfied only with something final, decisive and authoritative. The Roman Catholic places authority in the Church, and generally in the Papacy and the Church Councils. Most Protestants have made the Bible their religious authority, "the infallible rule of faith and practice." Some years ago I was delegate to the General Assembly of the Presbyterian Church of the 
United States, when Prof. Charles Briggs, my esteemed teacher, was turned out of the ministry for teaching, amongst other heresies, that there were three sources of authority, the Bible, the Church and the Reason or Christian consciousness. The distinctive liberal element in Protestantism makes one's own Reason, or enlightened conscience, or the general Christian consciousness of the best men, as the authoritative voice on religious matters. It is the reason that examines the records and text of the Scriptures, that weighs the dicta of the Church, and decides what to accept and what to reject. Finally, for nearly all Christians, after disputing with each other over these various forms of authority, there will probably be a consensus that the final word, the authoritative statement, the teaching clear and restful, bringing peace and joy, is the man Christ Jesus, the Logos of God. Dr. Henry Van Dyke, at present* United States Minister at The Hague, has well said: "Christ is the Light of all Scripture. Christ is the Master of holy reason. Christ is the sole Lord and Life of the true Church. By His word we test all doctrines, conclusions, and commands. On His word we build all faith. This is the source of authority in the kingdom of heaven."

It is my opinion that in some such statement as this, Protestant, Roman Catholic, Greek, Koptic and Armenian, can all draw near each other. The Protestant can agree with the Catholic that the Church possesses authority; and the Catholic can agree with the Protestant that the Bible possesses authority, and both will agree that Christ, or per-

*Written in 1915. 
haps we should say, God, is the final source of all authority. If the soul, if one's thoughts, if one's aspirations, are left in a state of uncertainty, there can be no peace or repose. Discussions concerning constitutions are interesting and profitable for a time. Finally the time comes, when the nation grows tired of such discussions and demands a definite constitution, however imperfect it may be. So the average Christian, after full play of his independence, craves for some strong word: "This is the way, walk ye in it. This is the truth, accept it."

Authority is something solid on which to build. In the last resort, one can find rest only in God. $\mathrm{He}$ speaks with authority; He rules with authority. The Bible, the Church, the Sacraments, one's own reason, are all ways in which God reveals His authoritative word, but behind all is God, and $\mathrm{He}$ it is who gives authority to one and all.

\section{V.}

The Church of Rome cultivates the spirit and demeanour of reverence. As Miss Frances Cobbe has said, "Religion is reverence." Religion means a right attitude of man towards God. Reverence is this right attitude. As for man there should be respect; for God, reverence. "Honour all men; fear God; honour the King." "The fear of God-reverence for God-is the beginning of wisdom."

In Protestantism, amongst some of its exponents, there is a familiarity in religious expressions, in prayer and in preaching, in general demeanour in the sanctuary, and in discarding of the term sacred, that makes Christianity appear commonplace, rather 
than exalts it to the highest position in man's affections and worship. The Roman Catholic system trains character of another kind. Its worship is dignified, solemn, stately, inspiring, reverential. Entrance into the Church, as the entrance into the mosque of Muhammadans, is in the form, if not the spirit, of reverence. A reverential demeanour is more conducive to a reverential heart, than is a careless and thoughtless manner. The Catholic kneels and is quiet. Protestants in too many cases have turned their church buildings into clubs, their pulpit into a stage, and reverence into amusement. The Catholic approaches the Mass in feelings of awe; the Protestant in too many cases makes the communion table as of so little importance that he stays away and feels satisfied. With the Catholic the Church, the priest, the sacraments, and even the cemetery are all sacred, that is, set apart to God. With the Protestant nothing is common or unclean, or rather nothing is sacred and all things are the same. The reverential quality of the Church of Rome deserves the admiration and also the imitation of all Protestants. In this the Episcopal service has set an example, retaining that which is so fundamental to the teachings of the ancient Church.

\section{VI.}

Along with this reverential aspect of the Church of Rome is its cultivation of the devotional spirit. Reverence and worship, prayer and devotion, these are the twin virtues of religion.

Most Protestant Churches are closed, except in 
time of public service; every Roman Catholic Church has its doors always unlocked, that the weary and the troubled may enter within and in the quietness of the sacred place, kneel before the altar, silently repeat the devotional utterances of an established ritual, and amid hallowed surroundings lay open the heart to the presence of the Spirit of God.

The literature of the Roman Catholic Church is rich in books of devotion. Prayers, hymns, meditations, exhortations, and confessions, poured forth from the very depths of the soul, are the treasures left to coming ages by saintly men and women who lived near to God and felt God's thoughts. The books of devotion of a Bernard and an á Kempis, of a St. Theresa and an Assisi, are not for Roman Catholics alone, but for all Christians who feel the need of divine grace and the value of the upward look.

The Roman Catholic Church has many ways for cultivating and satisfying the devotional nature. Quiet places, a Retreat, the confessional, a mission, are all meant to help one in his struggle to be better. The Church, with its altar, places one in the right surroundings for being devotional. Whilst escape from the world is impossible for most Christians, there are ways provided for making this escape a reality, even if only for a day or an hour.

\section{VII.}

Along with this devotional character of the Church of Rome, it cultivates another form of devotion, that of devotion to the needs and sorrows of 
fellow-men. All through the centuries, and amongsi all peoples, and in all nations, there have been those who have denied themselves all that they might serve others. Self-sacrifice stands forth as one charm of the great body of sisters of charity. The meaning of entering the priesthood or a sisterhood is that of giving up all family ties, all personal property, and being set apart for the service of the Church.

The devoted lives of those who thus deny themselves all has ever won the praise of men. Such speak more powerfully than any sermon the essence of Christianity, which is the love of God and the compassion of Christ. As Christ healed the lepers, and turned not from them, so there have been those in the Catholic Church who have not shrunk from the most repulsive diseases and the most perilous situations. In my early school-days I was attracted by a priest with whom I was travelling, who had just passed through the scourge of the yellow fever in one of our southern cities.

Such are the ones who have gone forth to preach the Gospel and proclaim the Church to the millions outside the pale, and in doing so they have lived simply, yea, with self-denial and in true devotion to others. The Church of Rome was missionary, before any Protestant body, struggling for existence, had yet thought of being one. In India and China and Japan they were the advanced guard preparing the way for us Protestants.

\section{VIII.}

The Church of Rome has had a genius for adapting itself to all conditions of men. It is stable 
and stationary in dogma and creed; it may discountenance progressiveness, but it includes within the bosom of the one Church all varieties of Christians, conservative and progressive, theological and socialistic. As priests they may be warned not to go too far, but they are still members of the Church. The very learned and the masses of the ignorant, the aristocracy and the nobility, and the semi-civilized and the poor, all alike meet in the same place of worship and hear the same words of absolution.

The Church of Rome has gone round the world and adapted itself to every form of government and to all the varied social usages of different nations of men. All minds, all classes, all races, find something in the Church of Rome to attract them. And the Church knows how to use all; however eccentric one may be, the Church can give him some task to do. This adaptability of the Church of Rome proves that it is part of the Christian Church and has a mission in all the world and to all ages. This quality the Protestant does well to appreciate.

\section{IX.}

The Church of Rome has also done much for the cause of learning and art. The inspiration of Christian truths has stirred the soul to the highest music and to the most magnificent architecture, and to pure sculpture and beautiful painting. Many a cathedral is the nation's art-gallery. The Church of Rome has steadily cherished the aesthetic and artistic feelings of men. It has made use of men's skill for magnifying the mission of the Church and re- 
vealing the purpose of God amongst the children of men. The Church in thus making use of all forms of art has set them apart to the sole service of God. The result is sacred art, sacred music, sacred song, and a sacred edifice where men meet for worship. With the highest ideals men have been inspired to their work of art far beyond the possibility of low motives and common-place themes.

The world would be the poorer, if there had been no Church of Rome thus to utilize and exalt the art of pure-minded men. They, too, were inspired like the men who wrote the sacred Scriptures, and their workmanship has ever been an inspiration, a lamp to the feet, the candle of the Lord, a means of grace. These excellences of the Church of Rome most Protestants will be ready to appreciate.

\section{$\mathrm{X}$.}

Having viewed these nine features of the Church of Rome, which the Protestant would do well to appreciate, there remains one more idea, deserving careful consideration, and that is, Protestantism should so appreciate Roman Catholicism, and Roman Catholicism should so appreciate Protestantism, that they will gladly join forces in combating materialism, godlessness and evil in the world. They can unite in works of mercy; they can cooperate in establishing hospitals and orphanages; they can cheer each other in the proclamation of the Gospel, and the spread of spiritual ideas, and the cultivation of the spiritual life. Whatever our views concerning the Holy Pontiff, we can rejoice at all 
his efforts for the bringing in the day of peace, of Christian brotherhood, of Church unity and the fellowship of the spirit. All advance made by the Church of Rome in establishing a Kingdom of righteousness should be reciprocated by all Protestants. As another has said, "Let Catholicism add to Protestantism its spirit of worship, its sacramental life, its unwavering faith, and its rich heritage of continuity with the historic past. And let Protestantism, on the other hand, add to Catholicism its fearlessness of learning, its stern conception of individual responsibility, and its emphasis upon personal religion. So shall we have in the great Church of the future, not an impoverished and shadowy form of Christianity fenced about with barriers of exclusion, but a Church which is enriched with all the wealth of the Christian ages." Then will come fulfilment of the petition of Christ, "that they all may be one." 
CHAPTER VII

\section{A TRINITARIAN'S APPRECIATION OF THE UNITARIAN}

In previous discussions we have noted that concord between Christianity and Judaism or Islam is harder to attain than between Christianity and the Pagan Faiths, Confucianism, Taoism and Buddhism, and still more is it harder between the Protestant form of Christianity and the Church of Rome. We are now to notice that the bond of union and concord between Trinitarian, and Unitarian Christians within the same fold of Protestantism is in many cases weaker than in the relations already considered. To be more precise the unwillingness to unite is more on the part of the Trinitarian Christian than of the Unitarian. This does not mean that the Trinitarian has no good reason for keeping separate from the small body called Unitarians, or even from Unitarian individuals, but it means that this is a divergence needing to be recognized. Most Trinitarians, it must be said, have no fellowship with Unitarians out of strong convictions. Their convictions are, indeed, so strong, that they look askance at an orthodox preacher who preaches in a Unitarian pulpit, or who extends courteous hospitality to any one who is a Unitarian, whether of the evangelical or radical school. 
It will help to make clear this peculiar condition which exists between Christians, if I state that when over a year ago I invited a Unitarian preacher to speak at the International Institute, an Institute open to all, and extended to him the hospitality of our home, I was not long in experiencing that my tolerance and good-nature were viewed as a heresy and an evil, and that as punishment for my misdeeds fellowship with the Institute or with myself personally, and in some cases liberal financial support, must come to an end. It will be seen, therefore, that the kind of concord to be considered and aimed at in today's discussion is not of a theoretic character, but is linked with actual experience. It may be that having been made to suffer for my views, the presentation of these views will be received with more than usual interest.

How it is that a tolerant attitude towards those who profess Unitarianism is worthy of disapproval, if not of censure, is best seen in the following quotation from an esteemed friend, long a liberal supporter of the International Institute, and a devoted Christian of the Episcopalian body, but whose ancestry was tinged with Unitarianism:

"To put Christianity on a merely humanitarian basis and be silent as to its unique and divine origin and claim is, to my mind, to alter and diminish the good news that Christ brought from heaven and suggests a doubt in the reality of our faith." As a matter of fact Unitarians do not reject the divine character of Christianity.

One preliminary remark is needed for understanding the position we take. Both the Roman 
Catholic Church and Protestant denominations have a conservative and a liberal school. With the former the liberal religious thinkers are called Modernists. The Presbyterians, Congregationalists, Episcopalians and nearly every other denomination contain those who are liberal in their views and spirit. Liberal religion is, therefore, a general term, and is not limited to Unitarians and Universalists. Not being a conservative in my theological thinking, my theme could not well be "A Conservative Christian's Appreciation of Liberal Christianity." Being, however, a Trinitarian Christian, I am able to discuss the theme "A Trinitarian's Appreciation of the Unitarian."

As stated in previous discussions, I consider that an appreciation of the good in others and in others' religious beliefs is all conducive to ultimate unity and accord. It is not our purpose to criticize or find fault with Unitarianism, but to help on the cause of religious goodwill by expressions of appreciation, and if Unitarians can find it possible to express appreciation of the orthodox, the evangelical, the Trinitarian Christian, the day of Christian fellowship and religious unity will be hastened in its coming.

\section{I.}

The first characteristic of Unitarians as a body is their independence in religious thinking. Whilst this is not the chief feature of Unitarianism, it is so important that it needs to be borne in mind in any review which is made of Unitarianism or of Unitarians. 
"As one star differeth from another star in glory," so does one Unitarian differ from another Unitarian. Some religious thinkers in the Unitarian body are nearer in their spiritual aspiration and their interpretation of Christian truths to orthodox thinkers than they are to fellow Unitarians, and yet because of their independence in thinking and their unwillingness to conform to exacting formularies, they are excluded from orthodox denominations and find a home among other independent thinkers in the Unitarian body, or, perhaps, remain aloof from churches of all names and kinds. The earlier Unitarians in the United States believed in the supernatural and in miracles, and accepted the usual view of the inspiration of Scrpture, but they also believed strongly in the right of private judgement and were too independent to remain even with Independents or Congregationalists.

Hence Unitarians have always fought shy of creeds as so many fetters to the free action of one's own conscience. Being found at the outset almost exclusively amongst the Congregationalists or, as called in England, Independents, they accepted the principle of independence to such a degree that they would not circumscribe the thoughts and beliefs of others, or allow themselves to be circumscribed, by any ecclesiastical domination or by any public confession of faith. The idea was expressed forcibly by Dr. William E. Channing, who wrote of Unitarianism in his day that it is "characterized by nothing more than by the spirit of freedom and individuality. It has no established creed or symbol. Its friends think each for himself, and differ much from 
each other." And again he wrote, "I am more detached from a denomination, and strive to feel more my connexion with the Universal Church, with all good and holy men. I am little of a Unitarian, and stand aloof from all but those who strive and pray for clearer light, who look for a purer and more effectual manifestation of Christian truth."

Thus in the very midst of independence there appears the natural longing, not for sects, but for the one "Holy Catholic Church," the Church Universal, with Christ alone recognized as its head, with Christ alone recognized as each one's Master. Until the Christian Church can be Catholic enough, comprehensive enough, to include all who promise to follow Christ, there must be divisions and sects. What needs to be noted is that the independence of thinking, the individuality of responsibility, which characterizes Unitarians, is always strongly set against sectarianism, but seldom against the idea of the one Universal Church of Christ. The spirit of Unitarian independence is not an extreme from the Church ideal of Roman Catholics; rather they approach each other. Unitarianism stands for independence on the one side and unity-Catholicityon the other. The former was the germ thought of the Protestant Reformation on the continent of Europe; the latter has always characterized the Church of Rome.

Radicals in the Unitarian body sought to combine these extremes in one or another way. On the one side they magnified freedom of religious thought, whilst on the other they went beyond mere fellowship with the one Christian Church, and sought for 
unity in the religious sentiment of all Faiths and all ages. They placed emphasis on Religion rather than on Christianity or Unitarianism. Their spirit of fellowship, never discarding independence of thinking, was of the widest kind; it was as wide as humanity.

Speaking of the controversy concerning these ideas amongst American Unitarians, Mr. Geo. W. Cooke says: "What was sought for was a method of reconciling fellowship with individuality of opinion, of establishing a Church in which freedom of faith for the individual shall have full recognition."

It was not until 1894 that the General Conference of Unitarian Churches agreed to the following statement as to their religious belief :

"These Churches accept the Religion of Jesus, holding, in accordance with His teaching, that practical religion is summed up in love to God and love to man. . . We cordially invite to our working fellowship any who, while differing from us in belief, are in general sympathy with our spirit and our practical aims."

The Basis of Union of many Unitarian Churches simply reads: "In the love of truth, and the spirit of Jesus Christ, we unite for the worship of God and the service of man."

It can be easily seen that independence in religious thinking, that strong individuality of character, that freedom of the human conscience, all conditioned by the widest spirit of fellowship, is a great force in the redemption of the world and in the development of a high type of civilization. It means vigour of mind and of character. It denotes un- 
daunted courage. It forms the stuff of which reformers and martyrs are made. It is the essence of Protestantism, and it does not, at the same time, overthrow Catholicity. By it inspiration is given to a masterful leadership in the sphere of morals. That which strengthened the arm of Puritanism has been the strength of Unitarianism. Moreover, as an indispensable quality, it has entered into individual lives in all branches of the Christian Church, and even in other religious Faiths. It is a quality which the Trinitarian and any other type of religious thinker will find it hard not to appreciate, to commend and to extol.

\section{II.}

With this dominating characteristic of independence, the Unitarian also deserves appreciation for the emphasis he places on the Unity of God. Unitarianism is thus not the product of negative and destructive criticism, but of belief that is positive and of thinking that is constructive. Its essence is the central thought of all religions. It lays a foundation for all religious doctrine in pure Theism. It directs humanity to uprightness of character by directing him to a clear, unequivocal worship of the one living and true God, and of implicit trust in His love and allegiance to His commands. Like Judaism, like Islam, like the purest form of all Religions, whether Confucian, Buddhist, Taoist, Brahman, Zoroastrian or any other, it teaches monotheism with no reservation, modification or limitation. The greatest of all religious beliefs, as affirmed by the 
experience of the ages, is made, it might almost be said, the one belief of the Unitarian.

Unitarianism, as in the right of private judgement, is the most Protestant of all Protestant bodies, for it originated as a protest against tritheism or the tri-personality of God-a false interpretation of Christianity. Like Muhammad, the Unitarians turned back to the fundamental doctrine of God's unity. In their reaction from false conceptions of the Godhead, they may at times have seemed also to condemn those who accepted the Trinity, as well as those who taught Tri-theism. As a result of the same reaction, it has frequently come to pass that not only those who in their thinking of three Gods criticize and denounce Unitarianism, but even those who worship one God but accept a Trinitarian conception of God, have also, in their thoughtlessness, condemned where they should have commended.

This protest against tri-personality in God, and this emphasis placed on the unity of the personality of God, has helped to preserve the real orthodoxy, the truthfulness of the Trinitarian conception of God. There is no doubt that the tendency of mankind has been to forget God, that is, to forget Him as One, and to stray away into erroneous conceptions which are polytheistic. There is also no doubt that the doctrine of the Trinity has too often been so explained as to imply the presence in the world of three Beings, each called God, with three distinct personalities, and three wills, and that worship ascends in one's thought not to God, but to three Gods. Hence the value of Unitarianism, which the correct Trinitarian thinker can appreciate, is its 
appeal to man to remain true to God, and to have no other gods before him. Joseph Cook of Boston, to escape condemnation from Unitarians, gave an interpretation of the Trinity, which is free from these erroneous conceptions. I quote his words:

"There are not in God three wills, three sets of affections, three consciences, three instincts. . . . I will resist the proposition that there are in God, three persons in a strict, colloquial, literal, modern sense. . . . The word person implies a species. If you say there are three persons in God, and mean by that word just what you mean by it on the street and in the parlour, you assume that these persons are individuals in a species; and my reply is that there is no species of Gods outside of polytheism.

Have there not been teachers who have held that there are three wills in God? Yes. Have there not been in New England intelligent Christians who have worshipped three beings in imagination, although in their thoughts they have asserted that God is one? I fear there have been, and that there are yet. . . . The luminousness, the colour and the heat (of the sun), Father, Son and Holy Spirit, three subsistences in one substance all enswathe us here and now."

As a matter of fact the interpretation given to the doctrine of God by Unitarians has entered into the thought and phraseology of Christians in orthodox Churches. The language of William E. Channing and James Freeman Clarke is not much different from that of many evangelical preachers. The explanation of the doctrine of the Trinity given by Joseph Cook can hardly give offence to a Unitarian, 
and yet this distinguished lecturer was regarded as a strong defender of orthodoxy. Without some protest from Unitarians, there would be a danger that the Trinitarian conception of God would break the bonds of orthodoxy and become a dangerous heresy. Unitarianism has, on the one side, been a stimulus to the truth that God is One, and on the other it has prevented the false thinking that there are three personalities each called God. The Trinitarian is thus warned that as the essential and indispensable truth is that God is One, so there must be no conception of the mind and no form of phraseology that would leave the impression that there are three Gods.

The illustration used by Joseph Cook helps to explain the doctrine of the Trinity without subverting the doctrine of God's Oneness. As the one sun has white light, the colours of the rainbow, and also heat, so the one God has three ways to show Himself to the world.

The illustration found at the beginning of the Gospel of John has supported the Trinitarian in his belief, and also restrained him from the error which Unitarians specially condemn. God is one, but He manifests through the Word. One's words make known the meaning of the heart. To say that words proceed from the mouth of a person or to say that that they proceed from a person, is all the same. To hear one is to hear his words. Thus the Wor! of God-His eternal manifestation-is not separate from God; the Word is God. So, too, a Breath, a Spirit, is spoken of as proceeding from God. A person without the breath of life ceases to be; his spirit has left. So, for God to exist means that His breath, 
His spirit, remains. If we say that the breath of God is breathed upon mankind, we mean only that God is at work amongst men and influences all men. God as the great First Cause, God as the Word, God as the Spirit, is one God, but appearing in three different ways to the thought of man.

The baptisimal form, which specifies the Son, bears more upon the nature of Jesus Christ, than upon the doctrine of the Trinity, and this is to be considered under a later head.

Any one who examines the Scriptures will acknowledge that the one vital truth, summed up in the First Commandment given to Moses and through him to the world, and permeating all the Books of Old and New Testaments, is that for which Unitarianism stands, namely, God is one. The passages which point to God as Triune are few, and this fact should stand as evidence that the doctrine of the Trinity is not as vital as that of God's Unity. The doctrine of the Trinity is a great mystery, is philosophical in character, and taxes the faculties of the mind. Being such, it can not have the same place in the creed of the Christian or in his life, as that which is fundamental to religion, and which the Unitarian magnifies, namely, "Hear, O Israel, the Lord our God is one God." If the Unitarian sincerely believes in God, worships God, and seeks to obey God, and if the only fault to find with him is that he does not think of God in the same way as others do, there is good reason why he and the Trinitarian can have fellowship with each other as they have with God, and that each should appreciate the 
other, ceasing to be antagonists and becoming friends and allies in the contest with evil.

\section{III.}

A third feature of the Unitarian's belief deserving the hearty appreciation of all other Christians, is the great teaching concerning the immanence of God in the universe and particularly in man. And here, too, the Unitarians and many of the orthodox thinkers approximate to each other. We have already seen how the principle of independence in religious thinking approximated to the spirit of the Protestant Reformation, while the desire for followship with the one Church Universal, as opposed to sectarianism, approximates to a cardinal teaching of the Church of Rome. The second great principle, of belief in one God, approximates not only to the monotheistic Faiths, but to the very orthodox Calvinists, who dwell much on the sovereignty of God. God as sovereign, as a Being Supreme over all, was the distinctive Hebrew idea, which passed over into Christianity except that it was modified to the extent of changing sovereign or Jehovah into Father. Even as Father, according to this Hebrew phase of the one truth, He exercised from heaven his fatherly sway over men on the earth.

Along with the Hebrew conception of God, there entered into Christianity the Hellenistic conception that God is immanent in His universe, that the Father is immanent in His children. So the Apostle Paul, preaching at Athens, used the familiar phrase 
that, "God is not far from every one of us, for in Him we live and move and have our being." The Hebrews, indeed, were not totally devoid of this idea, but the idea received new force by contact with the Greeks, especially the idealism of Plato. As Professor D. C. McIntosh of Yale University has said, "The God of practical religion is transcendent; the God of mystical religion is immanent, especially in the mystical experience itself. Christianity, coming out of Judaism, and going forth into the Hellenic world, felt called upon, and also able, to retain the values of both points of view, and to reconcile two seemingly contradictory theologies."

This happy combination of early Christianity characterizes Unitarianism. Like all monotheistic religions, it has magnified what we may call the status of God, making Him supreme over all. Like all, whose love and adoration go forth spontaneously to this Supreme Being, the All-God, it has brought God from heaven to participate in the affairs of this present earthly existence, as an immanent, as well as transcendent, God.

These two aspects of the divine nature being rightly presented, commend themselves to the mind of the Jew, the Moslem, and the Confucianist, such as speculations on the Trinity fail to accomplish. For Taoists, Buddhists and specially Brahmans, the immanence of God is a magnetic power, such as the limitation of this immanence to one person fails to be.

The immanence of God, as taught by Unitarians, is akin to the doctrine of God's Providence, as taught 
by the rigidly orthodox. Here, then, the Calvinist should be able to link hands with the Unitarian.

Though Unitarians are supposed to be adherents of Arius, yet in this particular doctrine, or rather life-principle, they are more akin to the ideas of Athanasius. Even concerning Jesus Christ, Unitarians find more in Athanasius than in Arius, with which they can agree. "Consciously or unconsciously," says A. N. Blatchford, "Athanasius was in reality contending for the Greek conception of the Deity, which was that of the immanence of God in human nature; whilst the estimate of God formed by Arius was that of God transcending all nature, and whose ineffable substance no created being could share, an estimate founded upon the venerable Hebrew idea of God as supreme, apart from and above all."

English and American Unitarians sprang into being almost as much out of protest to an excessive supernaturalism, as to the implication that the $\mathrm{Su}$ preme Being was tri-personal. Defenders of the Faith, like Bishop Butler in his "Analogy," were equally strong with Unitarians of a later day in recognizing the omnipresence of God-a truth apparent enough on the pages of Holy Writ. The transcendentalists of New England, Emerson, Hedge, Alcott and Clarke, who were all affiliated with the Unitarian movement, and similar thinkers in Old England, Coleridge and Wordsworth, and later Browning and Ruskin, Unitarian in sentiment though not in communion, made much of this mystical teaching of God's presence in all things and in every soul. It is, perhaps, the way that Unitarians have expressed the truth that has made it a striking 
characteristic of Unitarian teaching. And we may add, that it is this type or tone of thinking, this recognition of God's presence, that has saved Unitarianism from becoming a cold Deism.

It was Benjamin Franklin who proposed to the Continental Congress that each day of their sessions begin with prayer. His reason was expressed in the usual phraseology of his day: "The firm conviction to which I have come is that God rules in the affairs of men, and if a sparrow cannot fall to the ground without His notice, an empire cannot rise without His aid."

The Rev. James Freeman Clarke, one of the spiritual and mystical teachers of Unitarianism, a man known by his great work on "The Ten Great Religions," after referring to the doctrine of the Trinity as "a system of metaphysics," "a system of dialectics," a "logical puzzle," speaks in glowing language of God's immanence in the world. We can all agree with what he writes concerning God: "We open our eyes and minds and hearts, and we find Him everywhere in nature, in life, in all beauty, in all history. Everywhere that divine power is working around us. We see it in all the beauty which is manifested in the mountains, clouds, and seas, and brooks, and sunrise; in all the history of the human race; in childhood, and youth, and society; in business, in pain, and in joy; in all the riches of the world; because in all of them there is some manifestation of the divine truth and love, and $\mathrm{He}$ has left no race and no family of mankind orphans, without some knowledge of Himself." The spirit of this belief is the spirit of the prayer-hymn, written by a 
Unitarian, Mrs. Sarah Flower Adams, "Nearer, my God, to Thee."

\section{IV.}

From this conception of God's immanence in every soul, there comes the collateral conception of man's worth and dignity. Unitarianism revolted from the extreme teaching of the orthodox that man is totally depraved. It recognized the moral nature of man as a gift of God, and in so doing ennobled humanity.

The rigid dogma of the Dark Ages concerning man's sinfulness - and the Dark Ages corroborated the dogma-was first pierced by the light through the great movement known as the Renaissance, when men awoke to the fact that God is ever speaking in the human reason and that man, as said the Psalmist, is made "a little lower than the angels."

Even after the Renaissance and the Reformation, Protestant theologians followed the teaching of the Church of Rome as to man's apostasy, and inability to do the right. Arminian theology, and then Unitarianism, came in to soften the hard dogmas, to inspire men with hope, and to serve men for action by a sense of personal responsibility as due to personal ability.

A simple illustration of the way this conception gave rise to Unitarianism is seen by the way it entered into the mind of Theodore Parker, when he was a little child of only four. The story is told by Theodore Parker himself, and the words were the last he ever wrote as he lay dying in Italy. These are his words : 
"When a little boy in petticoats in my fourth year, one fine day in spring, my father led me by the hand to a distant part of the farm, but soon sent me home alone. On the way I had to pass a little 'pond-hole,' then spreading its waters wide. A rhodora flower in full bloom attracted my attention and drew me to the spot. I saw a little spotted tortoise sunning himself in the shallow water at the root of the flaming shrub. I lifted the stick I had in my hand to strike it. But all at once something checked my little arm, and a voice within me said, clear and loud, 'It is wrong!' I held my uplifted stick in wonder at the new emotion-the consciousness of an involuntary but inward check upon my actions-till the tortoise and the rhodora both vanished from my sight. I hastened home and told the tale to my mother, and asked what it was that told me it was wrong. She wiped a tear from her eye with her apron, and, taking me in her arms, said, 'Some men call it Conscience, but I prefer to call it the Voice of God in the soul of man. If you listen and obey it, then it will speak clearer and clearer, and always guide you right; but if you turn a deaf ear or disobey, then it will fade out little by little, and leave you all in the dark and without a guide. Your life depends on your heeding this little voice.' I am sure no event in my life has made so deep and lasting an impression on me."

This story tells a simple truth, which, devoid of all theological disputations, Christians, and those who are not Christians, will hardly care to deny. The truth lies embedded in the teachings of China's Sages, and for this reason, if for no other, Unita- 
rian Christianity should be the form naturally acceptable to the Chinese.

The Rev. William E. Channing, who represented the spiritual type in Unitarianism, once said, "I am surer that my rational nature is from God, than that any book is an expression of His will. This light in my own breast is His primary revelation, and all subsequent ones must accord with it, and are in fact intended to blend with it and brighten it."

This conception of man's nobility, or rather of man as recipient of God's revelation, of man, in other words, with a conscience, has entered into nearly all branches of modern Church life. The Unitarian teaching in this respect has been made a part of the teaching of Trinitarian preachers, if not of Trinitarian theologians.

The Rev. George A. Gordon of Old South Church of Boston, a liberal Congregationalist, has penned these words: "It has become obvious to competent judges in all denominations that Unitarianism in the hands of Channing and his successors rediscovered the Christian doctrine of man." And again: "If with the Trinitarian we say God is Father, with the Unitarian we must say man is the inalienable child of God; if with the Trinitarian we claim that there is a special, ideal incarnation of God in Jesus Christ answering to his vocation in the history of religion in the earth, we must contend with the Unitarian that there is a universal incarnation in mankind in virtue of which man is man with the impulse of the Eternal in his heart. In failing to see in the positive message of Unitarianism the complement to what was highest in their own faith and the correc- 
tion of its malady of errors about man, the masters of the New England theology made a supreme mistake."

\section{V.}

As the living truth of God's immanence leads to the exhilarating truth of man's nobility of nature, so the truth of man's nobility leads to the truth of the supreme nobility of the personality of Jesus Christ. While the way Unitarians have represented Jesus has brought upon their heads severe censure, we venture to point out in what way the Unitarian view of Jesus can fairly deserve the Trinitarian's appreciation, in fact, how near some Unitarians are to Trinitarians in the essential quality of this central truth of Christianity.

Some Unitarians are Arians, believing that Jesus was only a man; others, when we come to analyze their faith and thinking, are more like Athanasius, who believed not only in a Triune God, but that Jesus was the God-man, the incarnation of the Second Person of the Godhead. In making this last statement, we realize that the likeness of the Unitarian to Athanasius is unbelievable; it is only when we come to the inner thought of the doctrine about the person of Jesus, that we are able to detect a likeness.

The distinctive Arian type of mind was the Hebrew type, impressed not only by the Oneness of God, but the supremacy of God. Of the Hebrew type, Dr. Henry Van Dyke has correctly said, "that the idea of incarnation was foreign to the Hebrew mind. There was no race in the world that held so 
strongly to the thought that God was solitary, unsearchable, and incommunicable." Beyond the two ideas that God is one and that Jesus was a man, Unitarians have little in common with the early Arians. As already shown, Unitarianism has made much of the mystical idea of God's immanence, an inherent idea in Hellenic philosophy, and with this idea there came the idea of universal incarnation. As a result, the idea of special incarnation in Jesus Christ, the idea which took possession of Athanasius as opposed to the ideas of Arius, has been accepted by Unitarians of the more mystical and spiritual type.

Here, then, we have three ideas in Unitarianism which the orthodox Christian is bound to accept. One idea is the real humanity of Jesus Christ. The teaching is a part of orthodoxy, as of Unitarianism. Dr. Henry Van Dyke, a Presbyterian, in his book "The Gospel for an Age of Doubt," explains the argument of the book in the following language: "It accepts without reserve or qualification the perfect humanity of Christ. The life which Christ lived on earth was a veritable human life. The person who lived it was the Son of God. The mind that was in Christ was a single mind, and His will was the expression of an undivided personality. The Godhead that was in Him was such as manhood is capable of receiving." Another has said: "Unitarianism in declaring the humanity of Jesus does not bring the Christ down but lifts humanity up."

The Rev. Clay MacCauley, an ex-Presbyterian minister, now head of the Unitarian Mission in Japan, in his thoughtful book on "The Faith of the 
Incarnation," says very correctly: "In all Orthodox creeds Jesus Christ has been presented as, in a true sense of the word, human. It is one of the memorable distinctions of the Roman Catholic and the Protestant orthodox theologies, that they have invariably taught the proper and complete humanity of Jesus."

Moreover the humanity of Jesus, which is taught, is complete. Jesus did the will of his father to such a perfect degree that $\mathrm{He}$ had the right to be called the Son of Man, and He showed forth the spirit of God to such a perfect degree that $\mathrm{He}$ had the right to be called the Son of God. The great Unitarian preacher, Dr. Henry W. Bellows, speaking in 1866 in Cooper Institute, New York, a building erected by the Unitarian philanthropist, Peter Cooper, used these words: "Unitarians of the school to which I belong accept Jesus Christ with all their hearts as the Sent of God, the Divinely inspired Son of the Father, who by His miraculously proven office and His sinless life and character was fitted to be and was made revealer of the universal and permanent religion of the human race."

The second idea in the Unitarian teaching concerning Jesus Christ is that, having His life full of God, $\mathrm{He}$ is also recognized as a divine man. They hence speak of the divinity of Jesus rather than of his Deity. And here we quote from the Rev. James Freeman Clarke, to see the truth that lies behind this expression: "In rejecting the technical and theological doctrine of the Deity of Christ, we do not believe Christ less divine, but more. To say that Christ is God, unless we know what we mean 
by it when we say it, does not show God in Christ; does not make him a revelation of God. It is to see something divine in Christ which brings us to God; and that is what he came for-to bring us to God."

A third idea is taught by some Unitarians of the more spiritual type and that is that Jesus Christ was the incarnation of God. They do not say, the incarnation of the Son of God, and they do not limit the incarnation of God, any more than His immanence, to the one man, Christ Jesus. This idea of "universal incarnation in mankind" is just that teaching in Unitarianism which the Rev. George Gordon has expressed as essential to orthodoxy. So the Rev. Clay MacCauley interprets the idea: "Our interpretation of the Christology now finding place in the faith of the followers of the Christ, is that in Jesus of Nazareth there was 'God manifest in the flesh;' but that God was incarnate in Jesus in no way essentially different from that of His incarnation in all human souls. Whatever difference there was between Jesus and other men was in the degree of the Divine Communion and manifestation, not in its kind."

This conception of "God manifest in the flesh," of "God in Christ reconciling the world unto Himself," is in the name which he received, "Immanuel-God with us." Phraseology like this, and ideas like this, are current in the pulpits of orthodox preachers, such as the distinguished Americans, Phillips Brooks, Charles Cuthbert Hall, Lyman Abbott, Henry Van Dyke, and George A. Gordon. There is no doubt in my mind that this form of presenting Christianity, rather than the usual form, is the form 
which Moslems and those who adhere to other Faiths, can accept with most of value to their personal spiritual life.

The ideas of Unitarians concerning the person of Christ-ideas, be it noted, which are not all of the same mould-have greatly affected Christians who retain connexion with Churches not Unitarian. This has been specially so since the days of heated controversy passed away. In controversy points of antagonism receive the emphasis. After controversy, as after war, there comes an agreement and reconciliation.

The doctrine of the person of Jesus Christ is a complement to the doctrine of the Trinity; any consideration of the one inevitably leads to a consideration of the other. It is over these two complementary doctrines that Unitarianism has been put to the test. The re-action of Unitarian thought on Trinitarians is seen as much in the views held concerning Jesus Christ, as those concerning the Trinity.

The influence of Unitarians has affected two types of mind in orthodox Churches. Those who approach Christianity intellectually are still fascinated by thoughts-or speculations, if you prefer to call them -about the Trinity. They, therefore, approach the person of Jesus from the God-ward side. In the change produced in their minds by the silent influence of Unitarianism, they give up the old phrase of God sending His Son, and adopt, instead, the phrase of God manifesting Himself in Jesus Christ. They also make use of the Logos idea, of the pre-existent Christ, as pointing to the eternal manifestation or 
expression of the invisible, ineffable, incomprehensible God; and then accept, with the Gospel of John, that in the fulness of time, this Logos or the Word, this manifestation of God, was centered in the person of Jesus Christ "the glory as of the only begotten of the Father, full of grace and truth." Thus the Deity dwelt in Jesus, who of necessity was divine as well as human. Jesus was the incarnation of God, this is the thought, rather than the disputatious assertion that Jesus was the incarnation of the Son of God. They agree that Jesus by his perfect devotion to God's will was, indeed, the Son of God, but they are not zealous for maintaining that in the Trinity from all eternity there was a Father and a Son, though they accept the expression of God the Father and of the Logos or the Word. The Rev. Dr. Henry C. Mabie, in his different works, has given clear expression to this truth. In one place he says: "The Logos becoming historic in Christ is pre-eminently the vocalized reason of Deity to us-one says 'the intelligible expression of the Deity.'" And again: "Grace then is monotheistic; it is to be construed from the view point of one Deity rather than from any apparently tri-theistic basis."

The larger proportion of Christian believers in these days take but little interest in speculation, even when it is called religious. Others approach it from the practical side. In their practical viewpoint they approach the person of Jesus from the man-ward side. God as such is viewed as the Father and as one. Jesus as born an historical character, and by his life and death wrought salvation to the world, became the highest type of man, and by the 
complete possession which God's Spirit had upon him, he became the Son of God. After his death, God's Spirit carried on his work in the hearts of men. To such minds, the Trinity is an historical series : first, God as Father of All; then Jesus Christ the Son of God; and finally the Holy Spirit. This simple historical enunciation of Christian truth concerning Trinity and the person of Jesus Christ appears in the Apostles' Creed rather than in the Nicene and Athanasian Creeds, and this simple formulary is what Christians of today are most inclined to accept.

The intellectual and the practical types of Christians have both been affected by Unitarianism, under its influence they have been saved from many mistaken ideas and statements of the past, and have grasped the real significance of the Christian Gospel, which men in all lands and under all instructors can accept without dispute as the universal message of God.

\section{VI.}

Another teaching of Unitarianism is that of universal brotherhood. This is, indeed, no new doctrine, for it found expression in Jesus Christ and the great Apostle to the Gentile world, the Apostle Paul. Neither is it today a teaching which is confined to Unitarians, for Christians of all denominations have this expression much upon their lips. It is a popular phrase. Still it must be acknowledged that the rigidly orthodox have taught that there was only a brotherhood of those who believed in Jesus Christ, and, in many cases, of those alone who be- 
longed to their particular Church. The brotherhood was of the elect, or those whom one's Church could guarantee.

It must also be acknowledged that this teaching of the brotherhood of man is characteristic of modern Unitarian thinkers. Starting with a belief in the immanence of God, they have advanced to the confession of man's nobility of nature and of Jesus Christ's supreme nobility in spiritual qualities and divine likeness. The next step, that of human brotherhood, is the natural process of a logical mind.

The following is the simple statement agreed to by the Unitarian General Conference of 1913: "The Fatherhood of God; the Brotherhood of Man; the Leadership of Jesus; Salvation by Character; the Progress of Mankind; Onward and Upward forever."

Unitarians have thus been called Humanitarians, not so much because they have believed in the humanity of Jesus, as because they have believed that all men are endowed of God with humanitarian instincts, and that no higher duty rests on any man than that of devotion to the welfare of his fellow men.

In the language of the great Teacher our common duty is that of love to God and love to man. The teaching of human brotherhood is that in this love to all men there must dwell respect. Respect is natural, if we accept the inherent qualities of nobility and goodness belonging to all humanity.

President Abraham Lincoln was nearer to Unitarians in his thought than to orthodox Churches. This was what he once said concerning religion: 
"I have never united myself to any church, because I have found difficulty in giving my assent without mental reservation, to the long complicated statements of Christian doctrine which characterize their Articles of Belief and Confessions of Faith. When any Church will inscribe over its altar, as its sole qualification for membership, the Saviour's condensed statement of the substance of both Law and Gospel, 'Thou shalt love the Lord thy God with all thy heart and with all thy soul, and with all thy mind, and thy neighbour as thyself,' that church will I join with all my heart and all my soul." He evidently did not realize that this short statement of faith was characteristic of the Unitarian Church.

This broad humanitarianism has lain at the basis of internationalism. It moved the souls of Mazzini of Italy, Castelar of Spain and Kossuth of Hungary. The last one once used these words: "The Unitarian faith is the only faith which has a future; the only one that can influence the intelligent and interest the indifferent."

Likewise ex-President Charles W. Eliot in an address delivered in 1913 said: "I have been giving you reasons for the belief that the form of Christianity most likely to be accepted widely in the generations to come is the form familiar to the churches represented in this conference and expressed in the formula 'The fatherhood of God, the brotherhood of man, and the leadership of Jesus.' I am thinking, of course, not of present external appearances and immediate issues but of strong under-currents of thought and feeling, and age-long movements in 
which countless minds and wills, and many religious bodies will take part."

\section{VII.}

Unitariansm also represents a spirit of sympathy, tolerance and respect towards other religious Faiths. This is an off-shoot of the belief concerning man's nobility of nature.

"Revelation is not sealed;

Answering unto man's endeavour, Truth and right are still revealed.

That which came to ancient sages,

Greek, Barbarian, Roman, Jew, Written in the heart's deep pages, Shines today forever new."

This respect for other Religions has led to the study of Comparative Religions. Impetus was given by two Unitarian books, James Freeman Clarke's "Ten Great Religions" and Samuel Johnson's "Oriental Religions."

Prof. Francis G. Peabody, of an old Unitarian family, after visiting Japan, has said: "The great historic faiths of Buddhism, Confucianism, and Shintoism, which have moulded national life, are still operative in national instincts even when abandoned as personal creeds. The first task of the missionary under such circumstances is to understand the Oriental mind and its spiritual aspirations, and to discern therein the same impulses and motives which reappear, in purer form as he believes, in his Christian faith. 'One Gospel in many dialects',that was Martineau's fine phrase.' 
Ex-President Taft in a public address said: "Unitarians preach the gospel of sweet reasonableness, of love of God, of love of Jesus Christ, of tolerance. It has always seemed a wonder to me why all the world has not been Unitarian, and I think all the world is verging in that direction."

The Unitarian attitude to other Religions being one of tolerance, is not much of a proselytizing organization. Its interest in missions has been in the form of doing good and helping on all good causes, and of reviving the life that is within these other Religions. The Rev. Dr. William E. Channing once used these words concerning other Christian denominations: "Accustomed as we are to see genuine piety in all classes of Christians, in Trinitarians, in Unitarians, in Calvinists and Arminians, in Episcopalians, Methodists, Baptists, and Congregationalists, and delighting in this character whenever it appears, we are little anxious to bring men over to our peculiar opinions." This unwillingness to make converts characterizes social settlement work in England and America. It is this which has made the Unitarian body a small one, in comparison with those more zealous and also more sectarian, and has kept it from participating in missions, so long as the main idea has been to convert people from their traditional faith to Christianity. Unitarians need to understand that, leaving out the proselytizing motive, they have a duty as followers of Christ to live out Christianity and make the Christian message known to all the brotherhood of men.

Unitarianism in the old Arian form was as much missionary as was the Athanasian. The first trans- 
lation of the Bible into a vernacular tongue was made by Bishop Ulfilas for the Gothic peoples, and the Gothic type of Christianity was Arian. It was also Nestorianism which in the seventh century carried the Gospel to Persia and China. It was a member of the family of Socinus who carried the Gospel in sixteenth century to Poland and Transylvania, and it was the same Socinian scholars who translated the Bible into the Polish tongue. The Unitarian Churches of Hungary are the descendants of these earnest Christians of 350 years ago.

It is my conviction that Unitarians have a mission to perform in presenting Christianity, its faith and practice, in a new light to the non-Christian peoples of Asia. When the President of the American Board, Dr. Samuel B. Capen, came to Shanghai and spoke at our Institute, I told him of my desire to interest Unitarians in work for the uplift of China and he replied, "I wish you sucess. It will do them good. I am glad to hear that Unitarians in Boston have held their first Missionary Conference." We rejoice that Unitarians are tolerant of Moslems and the adherents of the ancient Religions, but this tolerance should not cool their ardour for being of service to men in need, whatever their name or race or land.

This head may well close with the words of the spiritual preacher of Scotland, the Rev. George Matheson:

"Gather us in: we worship only Thee; 
In varied names we stretch a common hand; In diverse forms a common soul we see;

In many ways we seek one promised land;

Gather us in.

"Thine is the mystic life great India craves;

Thine is the Parsee's sin-destroying beam; Thine is the Buddhist's rest from tossing waves;

Thine is the empire of vast China's dream:

Gather us in.

"Some seek a Father in the heavens above;

Some ask a human image to adore;

Some crave a spirit vast as life and love;

Within Thy mansions we have all and more:

Gather us in.

\section{VIII.}

Unitarianism will probably receive the appreciation of even the most orthodox for what it has accomplished in the social welfare of mankind. If the lack of missionary zeal has kept back Unitarians from carrying out their fundamental belief in human brotherhood to the extent of working for the good of non-Christian nations, they in their own countries have helped on many great movements for the improvement of the social conditions of their fellow-countrymen. American Unitarians, and those of Unitarian thought among the regular Churches in Europe, have taken the lead in social service. As the Rev. Thomas R. Slicer has said: "In the great body of thinking men effectiveness for social welfare rises above the necessity for intelligent agreement. Associations of men on the basis of practical 
reform are now maintained without regard to religious opinion."

The first peace Society in the United States, that of Massachusetts, was organized in 1815 through the efforts of the Rev. Noah Worcester "the Apostle of Peace", in the study of Dr. William E. Channing, who became one of the first Presidents. The World Peace Foundation was the donation of Edwin Ginn, and its active Secretary is Edwin D. Mead, both Unitarians. The Carnegie Endowment for Universal Peace is the donation of a radical in religion, and several of the Directors are liberal in their theology, such as Joseph A. Choate, Andrew D. White, Robert S. Woodward, Thomas Burke, Oscar S. Straus, and Henry S. Pritchett. The Peace movement has always been helped by Unitarians and by those of Unitarian thought among the Friends and in orthodox Churches.

It was Thomas Paine, who along with Benjamin Franklin, organized the first anti-slavery Society in the United States, and in the great anti-slavery contest Unitarians such as Channing, Theodore Parker, Ralph Waldo Emerson, Henry W. Bellows, Gerrit Smith, Thomas W. Higginson, Charles Sumner, Edward Everett, Frederick Douglass, Miss Mary A. Livermore, the poets Longfellow, Lowell, Bryant, and Whittier, and Mrs. Julia Ward Howe, author of "The Battle Hymn of the Republic," all took a part, that freedom might win its day.

It was Miss Dorothea Dix who brought reforms into prison life and started hospitals for the insane. It was Horace Mann who helped to mould the public school system of the United States. It was Dr. 
Samuel G. Howe and Col. Thomas H. Perkins who built homes and started schools for the deaf and the blind. It was Henry W. Bellows, Dorman B. Eaton, George William Curtis, Senator Hoar and Senator Burnside who pushed forward civil service reform. The City of Boston has been full of institutions permeated with the spirit of altruism, and these to a very large extent were started under Unitarian initiative. Unitarianism in its early days was characterized by humanitarianism and generosity. Father Taylor and his mission to sailors received encouragement from Channing and Emerson and was supported out of gifts from Unitarians. It was the many charities of Bostonian Unitarians which impressed Charles Dickens, another Unitarian, and brought forth words of high commendation, amid his criticisms of other features of American life. The founder of two American Societies for the Prevention of Cruelty to Animals, a form of kindliness, if not of humanity, were Henry Bergh of New York and Geo, T. Angell of Boston. The Tuskegee Institute and the Hampton Institute in their work to educate the negroes have annually received liberal contributions from Unitarians.

All Christian denominations and especially the Y. M. C. A. have of late made much of social service. Intellectual speculation and dogmatic controversy have given place to good works. This feature of Unitarianism from the very outset of its separation from Congregationalism - the silent, effective influence of a whole century -is something now regarded as of supreme importance, and receives, as it ought to receive, the commendation of all good Christians. 
Thus the Rev. J. T. Sunderland (the Unitarian who visited our Institute and brought upon us some unkindly admonitions) speaks of the Churches of the future: "They will be mightily interested in all such practical matters as schools and education and civil order, and social justice, and industrial betterment, and the putting of conscience into business and putting moral principles into politics, and temperance,-and the remedying of race and class injustices, and the abolition of war and all other movements and reforms, the aim of which is to dry up the dark streams of evil and crime and suffering in the world and to lift up men, communities and nations to higher planes of moral life."

This, in fact, is the essence of Christianity, as lived out by Jesus Christ, who went about among men doing good.

\section{IX.}

The last feature of the Unitarian body which we may appreciate, though not as much the more spiritual qualities, is the great influence exerted on and in literature, learning and high statesmanship. The Unitarian body has always been a cultured body. At times this fact has tended to puff up, not the thinkers themselves, but those who have dwelt in the sunshine of these men of genius. The philanthropists and reformers, whom we have already mentioned, were all men and women of pure refinement and true culture. Amongst American Presidents affiliated with the Unitarian body or in sympathy with its interpretation of life and of religion, have been John Adams and John Quincy Adams, Thomas Jefferson and Millard Fillmore, 
William Howard Taft, and, so far as the drift of his thinking is concerned, Abraham Lincoln. Chief Justice Marshall, and Justices Story, Wayne, and Miller; Vice-President Hamlin ; the statesmen Daniel Webster, John C. Calhoun, Allen G. Thurman, William E. Chandler, John D. Long and Justin D. Morrill; the scientists and educators, Lowell and Eliot of Harvard, Jordan of Leland Stanford, Hall of Clark University; John Fiske, Luther Burbank, Louis Agassiz, and John Burroughs; the historians, Bancroft, Motley, Prescott, Hildreth and Parkman; actresses like Fanny Kemble and Charlotte Cushman; critics like Emerson, Whipple, Ticknor, Bayard Taylor, Louisa M. Alcott, Bret Harte, Thoreau, Stoddard, James T. Fields, Charles Eliot Norton, Nathaniel Hawthorne, Oliver Wendell Holmes, Har-riet Prescott Spofford, and Edward Everett Hale,these are some of the many lights of American Unitarianism which have reflected their glory on Amercan life. The list in England and on the continent is smaller, for the Unitarian body is a small one, and those who hold to Unitarian views prefer to remain in the larger Churches or keep aloof from all. The beginnings of Unitarianism were with Locke the philosopher, Sir Isaac Newton the scientist and John Milton the poet. Its chief apostles in organizing the movement were Lindsey and Priestley. Some of the later names have been James Martineau, Brooke Herford, Stopford A. Brooke, Mrs. Humphrey Ward, J. Estlin Carpenter, James Drummond, Sir John Bowering, author of "In the Cross of Christ I glory", Miss Frances P. Cobbe, the Chamberlains of Birmingham, and Holts of Liverpool.

There are many liberal theologians, preachers and 
scholars in the Continental countries, but their connexion as a rule is not with the Unitarian Church. Reference, therefore, is unnecessary, except to note that those in sympathy with Unitarian and liberal religious thought have rendered great service to the cause of sound learning.

These nine points are sufficient to convince all who are interested in world movements and in unity among all nations and creeds, that Unitarianism has won a deserved place not only in the interpretation of Christian truth, in its selection of truths that are adaptable to human needs the world over. It has, in our opinion, succeeded as well as most schools of religious thought and most of the great Church organizations in representing the inner mind of Christ and the Kingdom of God. The Rev. George A. Gordon, comparing Unitarianism and Trinitarianism $\mathrm{m}$ their present effect on religious thought and practice, has said: "Preachers in all communions have in large numbers turned from Trinitarianism. It is not publicly denied or discarded; it is secretly confessed to have become no part of the working philosophy of religion. This mood will doubtless continue to prevail to some extent in all the churches. For certain minds the interpretation of the universe through man the individual is supremely attractive, because of its apparent simplicity and straightforwardness, its freedom from contradictions, and from the heavy, although at times transfigured, fogs that forever lie on the seas of mysticism. What is known as Unitarianism sets a distinct and persistent type of theism. It is well to recognize its principle of interpretation, its philosophical method, and its en- 
during fascination for certain orders of mind. It is well to confess that it is one of two rival types of Christian theism, and that today it is winning increasing confidence and support. It should be added that this type of theism holds, inconsistently as it seems to me, that its God is love in His inmost essence; that it carries over into its Deity pretty much the same moral content that one finds in its great rival type."

Whilst granting that Trinitarians and Unitarians will not be able to think alike on all religious questions, it is our hope that our expressions of appreciation of the Unitarian from the Trinitarian point of view will shew the reasonableness of larger co-operation in all spheres of religious investigation and activity. To our mind it is clear that if the Unitarian can be induced to enter on some forms of Christian missions, it should not be viewed as a calamity; neither should the one who suggests it be charged with "denying his Lord". Beyond this, it is our judgement that movements for Christian unity or Church ought not, at this stage of the world's prog= ress, to leave out Unitarians. If the Calvinist after years of fierce controversy with the Arminian is at last willing to turn the once-antagonist into a friend, and so to present the Gospel that one can hardly tell whether it is a Calvinist or an Arminian who is speaking, it ought to be possible for Unitarians and Trinitarians of a spiritual type and with spiritual aspirations to approach each other with a smile, rather than a frown, each ready to follow the Lord whithersoever He leadeth. 


\section{CHAPTER VIII}

\section{APPRECIATION OF JESUS CHRIST BY SKEPTICISM}

A personal reference as preliminary to a discussion of this important theme may be of some interest. In the village of my boyhood days, where my father, born in Scotland and nourished in Scottish theology and philosophy, was the Presbyterian pastor, we had as near neighbours three intelligent men who were skeptics not much different from blank atheists. One had been a distinguished politician and member of Congress from south-western New York. As a lad I felt drawn to these men, particularly to the last one. What was remarkable was that my father did not forbid me from talking with them, or from taking long walks over the fields with the ex-Congressman who was such a recluse. In my father's library, now forming part of our Institute's library, there were many heavy theological works of John Owen, Andrew Fuller, Richard Baxter, Jonathan Edwards, Joseph Bellamy and other kindred spirits of orthodox belief. There was only one work of fiction, "Uncle Tom's Cabin." A redcovered novel of Charlotte Brontë called "Jane Eyre," came from the booksellers by mistake into the parsonage, and was hid away under a pile of newspapers, until it caught the eye of my young inquiring mind, and was feverishly read, when my father 
was out, making pastoral calls. What was again remarkable was that along'side of this Calvinistic literature, there were Unitarian authors such as Theodore Parker, William E. Channing, S. T. Coleridge, F. H. Hedge and James Freeman Clarke, and such skeptical authors as Hume, Gibbon, John Stuart Mill, Rousseau, Renan, Strauss, Tyndall and Herbert Spencer. I love to take these books down from the shelf and note the marked passages, which tell me not only how these writers were moved to speak highly of religion and of Jesus Christ, but also how my father, rigidly orthodox and unswervingly conscientious (he walked as straight as he thought), was seemingly anxious to open his heart in sympathy to every doubter and ready to catch the first note of upward aspiration.

If I have today any liberal spirit to others who think differently from my own creed, even those who grope in the fogs of speculation or are wet with the dews of doubt, this may be put down to my heredity. My father was intellectually orthodox, but in spirit tolerant of others and sympathetic.

Some men, like the Apostle Thomas, are constitutionally doubters. For those of us who have passed beyond this doubting experience or who find it easy to believe, it is well to train ourselves to an appreciation not perhaps of all the arguments of skeptics, but of their mental difficulties and still more of the measure of truth or the phase of truth to which they with us give consent. Should they reverently and in all sincerity bow the head to Jesus of Nazareth, let us renew our confidence in the ultimate triumph, through a larger revelation in the individual soul, 
of the truth as it is in God, the One-All. Let us hear the words of Tennyson in "The Ancient Sage":

"Cleave ever to the sunnier side of doubt, And cling to Faith beyond the forms of Faith! She reels not in the storm of warring words, She brightens at the clash of 'Yes' and 'No,' She sees the Best that glimmers thro' the Worst, She feels the Sun is hid but for a night, She spies the summer thro' the winter bud, She tastes the fruit before the blossom falls, She hears the lark within the songless egg, She finds the fountain where they wail'd 'Mirage?!"

The way Christianity has spread these twenty centuries shows that there is something divine about its origin and Providential in its ever-widening ex= pansion. The very skepticism, yea, the varied forms of skepticism, which it has had to face from the very beginning,- - this with all the opposition, hostility and persecution-show that Christianity has come to this world-wide power through a religious struggle and a spiritual conquest. It is a case of "the survival of the fittest". What men have been enabled to believe, as a result of these struggles, is that which is reasonable to believe. The development made in religious thought is such that men of genius, philosophers, scientists, logicians, men truest to their better self, can follow Jesus Christ as the act of theoretical and practical wisdom.

Briefly and generally stated, the first form of skepticism in the early days of Christianity throughout the Roman Empire was opposition to a new system of religion as unequal to those which already 
had gained recognition among the leaders of thought in the different races of that wide-spread Empire. A few, as time went on, directed their criticism to the doctrine of the person of Jesus, especially as promulgated by Church leaders and Church Councils.

The next form of skepticism, which lasted the longest down through the Middle Ages, but never very openly expressed, was dissatisfaction with the Christian Church and disgust with its official representatives. The Church took the place of the Christian Religion, as the Religion had taken the place of Jesus Christ, and this very change gave greater scope for the assaults of skepticism. This assault on Christianity as represented by the Church took on a special literary, but unethical, form in the fourteenth, fifteenth and sixteenth centuries. This was the period of the revival of classical studies, of learning and art-the time of the Renaissance. As Dr. Luthardt of Leipsic has said: "The foundation of true morality was wanting. Classical studies resulted in a hitherto unheard-of licentiousness of life and motive. . . . The Platonic academy at Florence put the Platonic philosophy in the place of Christianity, and Savonarola strove with ardent zeal against heathen immortality and heathen belief, as defended by the highest prelates." The moral side of the Renaissance spirit, but equally opposed to the Roman Church, apeared in the Reformation, which brought in a revival in religion more than in learning. In this form there was not less belief in real Christianity, but more.

A new form of skepticism then arose both in 
Protestant and Roman Catholic communities, particularly in England, Scotland, France and Germany; this was the deism of the seventeenth and eighteenth centuries. Here was a denial of revelation. As Lecky in his "History of Rationalism" has said, "Of all the English deistical works of the eighteenth century, the influence of two and only two survived the controversy"-Hume and Gibbon. The movement, popular in high English circles, won favor also in France, where in most cases "it was frivolous, immoral, and denied the existence of God". In the French form it captivated Frederick the Great, but in Germany it had more moral earnestness than in France.

From the rise of Deism down to our own day, the assault on Christianity has come from so many quarters and assumed so many shapes that defencers of the Faith have hardly known which was to face, or whether offensive war would not be better than defensive. Skepticism has appeared now as materialism, now as naturalism, now as humanism, now as rationalism, and occasionally as agnosticism. This has been good for the Christian. It has kept him moving; rigidity has been impossible. He has had to modify his views or rather his interpretation; the more reasonable and adaptable his defence of the truth, the more inclined has the skeptic been to alter his own statement of what he has believed to be the truth. Learned men have come forward to magnify spirit as distinct from matter, to proclaim a living, ever-present Supreme Spirit as above and yet within all nature, to make clear that greater than Man or the spirit of man is the great All-Spirit, 
with which man's spirit may hold communion and by which all men may be moved to higher ideals, and to show that human reason, however great it is, draws its life from divine Reason and should strive to think in terms of the Infinite.

The liberal movement inside the Church has modified the extreme antagonism of materialists, rationalists, positivists, or whatever they be called, in the forces of skepticism. It was the Unitarian Lardner who wrote the best defence of historical Christianity in refutation of the arguments of Deists. It was Spinoza, Lessing and Schleiermacher who brought back God into His world and lowered the barrier between the natural and the supernatural. It has been Sir Oliver Lodge and F. W. H. Myers who have shown not only that there is spirit as well as matter, but that spirit rules matter and permeates matter. Thus Sir Oliver Lodge in his "Man and the Universe" says: "The spread of skepticism and dogmatic agnosticism is largely due to an attempted maintenance of incredible and materialistic dogmas by the orthodox, to the comparative neglect of the essential, the spiritual and the practical."

Skepticism in time changed the form of attack on Christianity into the form of historical criticism of the Scriptures. The result was a wider and more intelligent study of the Bible, both inside and outside the Church. The Bible became the greatest of all study instead of philosophic themes. In so far as the liberal element in the Church has dared to make use of the results of higher criticism, so far has the Bible as a spiritual guide taken on new power, and the critics such as Bauer, Wellhausen, Kuenen and 
Driver have never desired to destroy the true foundations of religious faith, but merely to know through accurate scientific investigation and historical criticism what is true and what is false as to these foundations. The result has been that men still go to the Bible as containing within its pages amid all the writers of many centuries an authoritative message from God, being "profitable for doctrine, for reproof, for correction, for instruction in righteousness, that the man of God may be perfect, thoroughly furnished unto all good works."

The final form of skepticism, being gradually developed through the last century, and particularly the last few decades, is the application of the scientific principles to an historical examination of the records concerning Jesus Christ. This historical criticism has advanced again to a philosophic study of the person of Jesus Christ. Here, too, liberal thought in the large communions, and specially in such bodies as the Unitarian, has helped to bring back to a religious faith those who might otherwise have withdrawn from the teachings and personality of Jesus Christ. The real test has come to be whether one will obey the will of God however made known, and whether one will follow Jesus as the supreme leader in spiritual truth, life and conduct. As Christianity has of late become more evangelical, so skepticism, it may also be said, has become evangelical. Nothing is more encouraging as to the progress of Christianity than that Christian and non-Christian, are turning to Jesus of Nazareth or to the Christ of God as the centre of all religion.

The more liberal conception of the mission and 
nature of Jesus as given by a learned scientist, is that expressed in the following words of Sir Oliver Lodge: "Through incarnation of the Christ Spirit certain aspects of Deity were revealed to humanity in a unique degree; but the more akin to ordinary humanity that incarnation can be considered, the more luminous is the teaching, and the better for the hold of Christianity upon the race. One of the lessons to be learned is the potentiality of the Divine latent in all humanity. . . . The Divinity of Jesus is the truth which now requires to be re-perceived, to be illumined afresh by new knowledge, to be cleansed and revivified by the wholesome flood of skepticism which has poured over it. It can be freed now from all trace of grovelling superstition, and can be recognized freely and enthusiastically: the Divinity of Jesus, and of all other noble and saintly souls, in so far as they, too, have been inflamed by a spark of Deity-in so far as they, too, can be recognized as manifestations of the Divine."

These varieties of unbelief, as seen in European history through 1900 years, can hardly be the same as the forms of unbelief as directed to Christianity in non-Christian nations of today, such as China or Japan or India. The first form which we have mentioned as appearing in the early days of the Christian Church-that of opposition from other competing Religions-appears also amongst these peoples who today are becoming acquainted with Christianity. The Brahman, the Confucianist, the Buddhist, will not always accept Christianity on the word of the Church, or, rather, on the word of the missionary. There will be years of competition between 
these ancient Faiths of Eastern Asia. All the other forms of skepticism which Europe has had will probably not enter into the experience of Eastern Asia, except perhaps the very last, that which concerns Jesus Christ. The results of the experience in Europe and America should enable Christian missionaries to bring to these populous nations the truths of Christianity, in a more acceptable way, especially "the truth as it is in Jesus". Thus, perhaps, a conflict between belief and unbelief may be avoided, and Jesus as Teacher, Guide and Master, yea, as Saviour and Lord, may be gladly accepted as an act of the highest reason. Christianity, if presented in the theological terms of the past, will arouse opposition amongst the intelligent men of these great nations, but if it be presented as, after the conflict, it is more and more being presented in the pulpits and divinity halls of the West by the more liberal school, it will command the respect and devotion of the learned here, as of the learned elsewhere.

It is our purpose to present the testimony of some of the leading skeptics, and of those who have stood outside the pale of the Church, concerning Jesus Christ. When the forms of skepticism were directed against the Bible, against the Church, or against what was called the Supernatural, there were fewer references to the personality of Jesus. Some of the names of this later period in European history are already known to educated Chinese, not so much, however, through their religious opinions as through their ideas on political and social problems.

Napoleon the First was too busy a man to think 
much of religion or to formulate for himself a system of belief or unbelief. His attitude was that of indifferentism. If he worshipped anything during his days of power it was Ambition and Destiny. When banished to St. Helena, he had leisure for reflection, and in his last will he declared, "I die in the apostolic Roman religion, in the bosom of which I was born more than fifty years since." In a conversation recorded with General Bertrand before his death, he is quoted as saying:

"Alexander, Caesar, Charlmagne, and myself founded empires. But on what did we rest the creations of our genius? Upon force. Jesus Christ alone founded his empire upon love; and, at this hour, millions of men would die for him."

And again: "Behold the destiny, near at hand, of him whom the world called the great Napoleon! What an abyss between my deep misery and the eternal reign of Christ, which is proclaimed, loved, adored, and which is extending over all the earth! Is this to die? is it not rather to live? The death of Christ-it is the death of a God!"

Before his time, one of the French encyclopedists, Diderot, atheistical in his skepticism, after listening to the strongly-expressed views of a company of infidels, startled them by the following assertion as to the Bible and Christ:

"I defy you all-as many as are here-to prepare a tale so simple, and at the same time so sublime and so touching, as the tale of the passion and death of Jesus Christ; which produces the same effect, which makes a sensation as strong and as generally 
felt, and whose influence will be the same, after so many centuries."

Rousseau is a name that carries great weight in China amongst advanced thinkers on the rights of man. In 1760 he wrote a book on education, wherein he gave his testimony concerning Jesus and his Gospel. For this discussion of morals and religion he was banished from France under orders of Parliament. The following are some of his words on the record of the Scriptures concerning Jesus, and on his own estimate:

"Is it possible that the sacred personage whose history it contains should be himself a mere man? Do we find that he assumed the tone of an enthusiast or ambitious sectary? What sweetness, what purity, in his manner! What an affecting gracefulness in his instructions! What sublimity in his maxims! What profound wisdom in his discourses! What presence of mind, what subtlety, what fitness, in his replies! How great the command over his passions! Where is the man, where the philosopher, who could so live and so die, without weakness, and without ostentation?"

And then he adds: "The death of Sokrates, peacefully philosophizing among friends, appears the most agreeable that one could wish: that of Jesus, expiring in agonies, abused, insulted, and accused by a whole nation, is the most horrible that one could fear. Sokrates, indeed, in receiving the cup of poison, blessed the weeping executioner who administered it; but Jesus, amidst excruciating tortures, prayed for his merciless tormentors. Yes, if 
the life and death of Sokrates were those of a sage, the life and death of Jesus are those of a God."

The one French writer who has made special study of the life and character, the mission and nature, of Jesus Christ, is Renan, who died in 1892. In his Hibbert Lectures of 1879 , he makes the statement that "the true miracle of nascent Christianity" was "the spirit of Jesus, strongly grafted into his disciples; the spirit of sweetness, of self-abnegation, of forgetfulness of the present; that unique pursuit of inward joys which kills ambition; that preference boldly given to childhood; those words, "Whosoever will be chief among you, let him be your servant'." In his "Life of Jesus", he speaks of Him in these words :

"This sublime Person, who daily presides still over the destiny of the world, we may call divine, not in the sense that Jesus absorbed all the divine, or, to use a scholastic word, was adequate to it, but in the sense that Jesus is the individual who has made his species take the greatest step towards the divine." And again, "Jesus is the highest of the pillars that shew to man whence he comes and whither he ought to tend. In Him is condensed ail that is good and exalted in our nature". His view of Christ is much like that of the spiritual school in Unitarianism. He says :

"Jesus has no visions; God does not speak to him from without; God is in him; he feels that he is with God, and he draws from his heart what he savs of his Father. Jesus never for a moment announces the sacrilegious idea that he is God. He believes that he is in direct communion with God; he believes 
himself the son of God. The highest consciousness of God which ever existed in the breast of humanity was that of Jesus." In another place, referring to his message to the woman at the well in Samaria, that "the hour cometh when ye shall worship neither in this mountain nor yet at Jerusalem, but when the true worshippers shall worship the Father in truth," he adds:

"On the day when he pronounced these words, he was indeed the son of God. He for the first time gave utterance to the idea upon which shall rest the edifice of the everlasting religion. He founded the pure worship, of no age, of no clime, which shall be that of all lofty souls to the end of time. Not only was his religion, that day, the benign religion of humanity, but it was the absolute religion; and if other planets have inhabitants endowed with reason and morality, their religion cannot be different from that which Jesus proclaimed at Jacob's well."

After referring to the Crucifixion of Christ, he thus apostrophizes: "Repose now in thy glory, noble founder. Thy work is finished; thy divinity is established. Fear no more to see the edifice of thy labours fall by any fault. Henceforth, beyond the reach of frailty, thou shalt witness from the heights of divine peace, the infinite results of thy acts. At the price of a few hours of suffering, which did not even reach the grand soul, thou has bought the most complete immortality. For thousands of years, the world will depend on thee! Banner of our contests, thou shalt be the standard about which the hottest battle will be given. A thousand times more alive, a thousand times more beloved, since thy death 
than during thy passage here below, thou shalt become the corner stone of humanity so entirely, that to tear thy name from this world would be to rend it to its foundations. Between thee and God, there will no longer be any distinction. Complete conqueror of death, take possession of thy kingdom, whither shall follow thee, by the royal road which thou hast traced, ages of worshippers."

$\mathrm{He}$ closes his fascinating work with these words:

"But whatever may be the surprises of the future, Jesus will never be surpassed. His worship will grow young without ceasing; his legend will call forth tears without end; his sufferings will melt the noblest hearts; all ages will proclaim that among the sons of men there is none born greater than Jesus."

When Renan was elected to the Chair of Hebrew in the Collége de France, his opening lecture contained views like these, and he spoke of Jesus as the "Incomparable Man". This caused the Catholic party, then strong in France, to bring about his removal from this chair, for which he was well fitted, to an inferior post as sub-librarian. It is of interest for us to see how far removed from the claims of deism was the belief of Renan. By acceptance of the new teaching of the God's immanence in humanity, he takes the position that Jesus was not only the greatest of men but was divine, as endued with the spirit of God. The positive statements of Renan concerning Jesus, though not his negative criticism, are those today heard in congregations of Christians who seek a message that meets the wants of the soul, by pointing to Him who is "the Way, the Truth, and the Life", the Incomparable Man, the Son of God. 
Having cited the testimony of four distinguished Frenchmen, who while skeptical as to many Christian doctrines, yet praised the character of Jesus and exalt him to the highest position among the sons of men, we now cite the testimony of four leading Germans. It is from Germany that we have heard most about Rationalism, and it is interesting to see its attitude to Jesus Christ.

The first one is Strauss, whose "Life of Jesus" created as great a stir in orthodox circles as did later the "Life" by Renan.. Renan's was the more popular of the two, but Strauss' was scholarly and solid, the result of careful historical criticism. His conclusions are no more to be taken as infallible than the conclusions of other students. The two volumes published in 1835 first attracted the attention of English-speaking peoples through the translation of the free thinker generally spoken of as George Eliot.

In one of his printed essays published in 1838 , his opinion as expressed is not as drastic as that which he is generally suposed to hold. He then says:

"If in Jesus the union of the self-consciousness with the consciousness of God has been real, and expressed not only in words, but actually revealed in all the conditions of his life, he represents within the religious sphere the highest point, beyond whom posterity cannot go; yea, whom it cannot even equal, inasmuch as every one who hereafter should climb the same height, could only do it with the help of Jesus, who first attained it. As little as humanity will ever be without religion, as little will it be without Christ; for to have religion without Christ 
would be as absurd as to enjoy poetry without regard to Homer or Shakespeare. And this Christ, as far as is inseparable from the highest style of religion, is historical, not mythical; is an individual, no mere symbol. To the historical person of Christ belongs all in his life that exhibits his religious perfection, his discourses, his moral action, and his passion. . . . He remains the highest model of religion within the reach of our thought; and no perfect piety is possible without his presence in the heart."

His ideas concerning Jesus are that his incarnation gives the idea of a wider incarnation of all humanity, whereupon the original fact is no longer needed as an object of belief. He thus writes:

"Faith, in her early stages, is governed by the senses, and therefore contemplates a temporal history; what she holds to be true is the external ordinary event, the evidence for which is of the historical, forensic kind, - a fact to be proved by the testimony of the senses, and the moral confidence inspired by the witnesses. But mind having once taken occasion of this external fact to bring under its consciousness the idea of humanity as one with God, sees in the history only the presentation of that idea; the object of faith is completely changed; instead of a sensible, empirical fact, it has become a spiritual and divine idea, which has its confirmation no longer in history but in philosophy. When the mind has thus gone beyond the sensible, and entered into the domain of the Absolute, the former ceases to be essential."

An even greater scholar of the Rationalistic type 
in Germany, an historian, theologian and scientific investigator, was Dr. F. C. Baur, a Professor in Tübingen University. He approached the study of Jesus Christ by a pure historical investigation of the New Testament Books. The Hegelian philosophy of Tübingen, that of God's immanence, also permeated Baur's conception of history, as it has greatly affected modern thought. Christianity, as he looks at it, is part of the development that runs through all history and is itself a development from the religious ideas of the past. It is "the ripe fruit of all the higher longings that had hitherto stirred amongst all branches of the great human family." Of this religion thus developed he says: "That the elements of a new religious development, which per se were already extant, should have concentrated themselves in the generation of a new life at one particular point and in one special individual,- - this is the wonder in the history of the origin of Christianity which no historical reflection can further analyse." He even adds that he, too, "acknowledges a certain supernatural character and a divine principle working in an especial manner" in this newlydeveloped religion of Jesus Christ. Dr. Baur also makes this striking statement: "That which exalts Christianity, as against all other belief, to the dignity of the absolute religion, is in the last instance nothing but the purely moral character of its facts, doctrines and requirements." He thus places emphasis on the moral purport of Christ's teachings, and life and mission, a view which has gained currency in modern Christian movements. In the same line he says: "All that belongs to the truly moral 
purport of Christ's teachings, as contained in the Sermon on the Mount, the parables ( etc.,--his doctrine as to the kingdom of God, the conditions of its membership whereby man is placed in a truly moral relation to God,-all this constitutes the intrinsic essence of Christianity and its substantial centre."

A third noted German, one of the great poets of all time, is Goethe, who lived before Strauss and Baur, dying in 1832. He thus writes of the religion of Christ: "The greatest honour is due to the Christian religion, for continually proving its pure and noble origin by coming forth again, after the great aberrations into which human perversity has led it, more speedily than was expected, with its primitive special charm as a mission, a family friend, a brotherhood, for the relief of human necessity." He also says: "I esteem the Gospels to be thoroughly genuine, for there shines forth from them the reflected splendour of a sublimity proceeding from the person of Jesus Christ and of so divine a kind as only the divine could ever have manifested."

The fourth German name is that of a great religious philosopher still living, Professor Rudolf Eucken. In the usual meaning attached to the word skeptic, Professor Eucken should not here be cited. His religious views are not of an unbeliever in all religious truth, but approach one branch of American Unitarianism. He does not accept the orthodox interpretation of Christianity. He represents philosophy rather than history. Having passed through the period of historical criticism, he says :

"The shaking of the historical foundations of the religious 
life goes still further: it is not merely that we are compelled to doubt particular items of their contents, it is that history itself no longer seems proper to serve as the foundation of religion." He then quotes Lessing's famous saying: "Accidental truths of history can never become the proof of necessary truths of reason," and Kant's statement, "That historical belief is a duty and belongs to salvation is superstition." Prof. Eucken then adds: "Can such a dissolution of the old blending of reason and history affect and shake any other religion more deeply than Christianity, which is the most historical of all religions?"

This philosopher thus speaks of Christ: "We can honour him as a leader, a hero, a martyr; but we cannot directly bind ourselves to him or root ourselves in him; we cannot unconditionally submit to him. Still less can we make him the centre of a worship. To do so, from our point of view, would be nothing less than an intolerable deification of a human being."

The thought here is that religion is something more than belief in any historical event, but concerns one's reason or consciousness in its intimate relation to God, the Absolute Being. Thus greater than Christianity is religion, greater than Jesus of Nazareth is the Christ of God, the Christ of theology, the Christ who still lives in human experience.

Whilst to most of us Christianity is cherished for its historical as well as mystical character, this new emphasis contains a truth which means much to each one's personal religion.

We now turn to four representatives of skepti- 
cism amongst the British, and see what they have to say concerning Jesus Christ.

The first name is Gibbon. In one place he speaks of "the authentic histories of the actions of Christ." In another he refers to "the purity of the Christian Religion, the sanctity of its moral precepts, and the innocent as well as austere lives" of the early followers of Christ. In another he speaks of "the pure and sublime idea which they entertained of the Supreme Being" and "of the inscrutable nature of the divine perfections." Speaking of Jesus of Nazareth, he refers to "His mild constancy in the midst of cruel and voluntary sufferings, his universal benevolence, and the sublime simplicity of his actions and character" and to the way men "misrepresented or insulted the equivocal birth, wandering life, and ignominous death, of the divine author of Christianity."

The second name, even better known to the Chinese from his views on political topics, is John Stuart Mill. "Who," he says, "amongst all the disciples of Jesus or amongst their proselytes was capable of inventing the sayings ascribed to Jesus, or of imagining the life and character revealed in the Gospels? Certainly not the fishermen of Galilee, as certainly not St. Paul." His view is that this story could not have been a human construction, but the story of an actual person who taught and lived. Mr. Mill then adds: "It is the God incarnate, more than the God of the Jews or of nature, who, being idealized, has taken so great and salutary a hold on the modern mind." Once again these words are used: "Not even now would it be easy, even for an unbeliever, to find a better translation of the rule of vir- 
tue from the abstract into the concrete than to endeavour so to live that Christ would approve our life." This learned, but doubting, thinker, also uses this remarkable language: "Whatever else may be taken away from us by rational criticism, Christ is still left: a unique figure, not more unlike all his precursors than all his followers, even those who had the direct benefit of his personal teaching. It is of no use to say that Christ as exhibited in the Gospels is not historical, and that we know not how much of what is admirable has been superadded by the tradition of his followers."

The third name is Charles Darwin. Admiral Sir James Sullivan mentions that when Darwin had expressed to him the uselessness of sending missionaries to the Fuegans, he replied that he "did not believe any human beings existed too low to comprehend the simple message of the Gospel of Christ." The Admiral then adds: "After many years he (Darwin) wrote to me that the recent account of the mission shewed that he had been wrong and I right, and he requested me to forward to the Society an enclosed cheque for $£ 5$ as a testimony of his interest in their good work."

A fourth English name is James Anthony Froude, who first intended to become a clergyman, but gradually slipped away from the Faith, as revealed in his "Nemesis of Faith". Notwithstanding his unbelief he retained reverence for true religion as one of love and trust. "Such a Creed," he said, "had it remained as it came from its Founder, would have changed the aspect of the earth. In that Religion hate would have no place, for love, which is hate's 
opposite, was its principle." Later he says: "Through Christ came charity and mercy. When his name and his words had been preached for fifteen centuries, there was none found who could tolerate difference of opinion on the operation of the baptism or on the nature of his presence in the Eucharist." This distinguished historian, who died in 1894, thus passes criticism on the Church and the formulated dogmas of the Church, but retains reverence for Christ and belief in his teachings as to the quality of an ethical life.

From the United States we select the names of only three skeptics to testify concerning Christ. The first American name is that of Thomas Jefferson, third President of the United States. He was skeptical, but it is hardly correct to call him a skeptic. He, as other Americans of that period, was greatly influenced by the free thought of France and the Deism of England. He was not, however, irreligious. In his home in Virginia he attended the Episcopal Church, and in belief he was a Unitarian. He was a student of the Bible, and made a collection of the sayings of Jesus, which the United States Government has since published. One of his remarks was, "The doctrines of Jesus are simple and tend all to the happiness of man." Again: "When we shall have unlearned everything taught since His day, and got back to the pure and simple doctrines He inculcated, we shall then be truly and worthily his disciples; and my opinion is that, if nothing had ever been added to what flowed from His lips, the whole world would at this day have been Christian."

The second name is that of Theodore Parker, who 
stands forth as a leader in Unitarianism, but has, like Professor Eucken, been looked upon in past days as a dangerous man. Whether misjudged as we think he is, or not, we take his testimony concerning Jesus Christ. In one of his eloquent addresses he says: "What words of rebuke, of comfort, counsel, admonition, promise, hope, did $\mathrm{He}$ pour out: words that stir the soul as summer dews call up the faint and sickly grass! What profound instruction in His proverbs and discourses: what wisdom in His homely sayings, so rich with Jewish life; what deep divinity of soul in His prayers, his action, sympathy, resignation! Rarely, almost never, do we see the vast divinity within that soul, which, new though it was in the flesh, at one step goes before the world whole thousands of years; judges the race; decides for us questions we dare not agitate as yet, and breathes the very breath of heavenly love. . . . Shall we be told, 'Such a man never lived; the whole story is a lie'? Suppose that Plato and Newton never lived; that their story is a lie! But who did their works, and thought their thoughts? It takes a Newton to forge a Newton. What man could have fabricated a Jesus? None but a Jesus."

The third name, likewise opposed to the traditional interpretation of Christianity, and classed amongst Unitarians, is the great scientist and historian, Professor John Fiske. He thus writes of Jesus: "The great originality of $\mathrm{His}$ teaching, and the feature that has chiefly given it power in the world, lay in the distinctness with which $\mathrm{He}$ conceived a state of society from which every vestige of strife, and the 
modes of behaviour adapted to ages of strife, shall be utterly and forever swept away. Through misery that has seemed unendurable and turmoil that has seemed endless, men have thought on that gracious life and its sublime ideal, and have taken comfort in the sweetly solemn message of peace on earth and good will to men."

Prof. Fiske has two chapters entitled "The Jesus of History" and "The Christ of Dogma," and he says: "From the dogmatic point of view Jesus is best known, from the historic point of view he is the least known. The Jesus of history is so little known just because the Christ of dogma is so well known." From the historical point of view Prof. Fiske notes how "powerful in the domain of ethics" is the Sermon on the Mount, then the two teachings of God's fatherhood and man's brotherhood, then the idea of God, and then he sums up, "From this conception of God flowed naturally all the moral teaching of Jesus, the insistence upon spiritual righteousness instead of the mere mechanical observance of Mosaic precepts, the call to be perfect even as the Father is perfect, the principle of the spiritual equality of men before God, and the equal duties of all men towards each other."

These out-spoken testimonies concerning Jesus Christ by fifteen distinguished scholars, who amid much unbelief and uncertainty have retained reverence for this supreme personality of human history, afford us ground for a few generalizations.

The first is that in the development of skeptical thought, as in that of religious belief and knowledge, Jesus Christ is more and more recognized as the 
ideal pattern in the spiritual world. As Sir Oliver Lodge has said, "Whatever view we may take of this Personality, we can most of us recognize it as the grandest that has yet existed on this planet." The late Professor Philip Schaff has also clearly shown the unique position of Christ: "It seems to be felt more and more, that $\mathrm{He}$ is, without controversy, the very best being that ever walked on this earth, and that an attack on His character is an insult to the honour and dignity of humanity itself. And this feeling and conviction becomes stronger and deeper as history advances. The impression of Christ upon the world, far from losing ground, is gaining new strength with every stage of civilization, and controls even the best thinking of His enemies." Were it only left for Jesus Himself to say, "Follow thou me," with no questioning as to each one's individual conception of His person and nature, the number of His followers would be far larger than when discipleship is expressed in human terms by human creeds. The critical mind of the real scholar, not the superficial vapourings of selfconceit, find Christ not repellent but one full of charm, persuasion and attraction. The working men of Europe and America and the great body of Socialists may not return to the Church, but they can be drawn to Jesus Christ.

The second point which impresses us is that the culmination of skepticism has been that of historical criticism of the Gospel records, rather than opposition from science or philosophy or irreligion. Christianity is thus more a matter of history than of speculation. This form of skepticism is for us, not to 
regret, but to rejoice in. The life of Jesus as lived on the earth, as a part of history, is the highest of all objects for historical criticism. What Christians must desire, if they are religious Christians, is that Christianity and particularly Jesus Christ be known as they really are, in other words that we have the truth concerning Christ, and that our knowledge of his person, even as a divine One, be accurate and conducive to the development of character.

The only thing that ordinary men have the right to expect, is that this part of human and universal history be studied in the same historical spirit or, what we may call, judicial temperament, as any other part of history. For an historian to slight the value and significance of history would indeed be strange and for him to do so because the history is that of Jesus, would be unjust. The results of historical investigation may in certain particulars be stated differently, but those who profess no great historical insight, demand that enough of history be left to form the basis of an historical as well as speculative religion. We want a real, not an empty religion, an historical not a mythical or non-existent Jesus.

Hence, when such men of historical mind as Renan, Strauss, Bauer, Gibbon, Froude, and Fiske, find, after all their probings and prunings, a real person called Jesus Christ, the general outline of whose life is contained in the four Gospels, we may rest content that our religion has an historical basis that is trustworthy. The Unitarian writer, the Rev. Howard N. Brown, pastor of King's Chapel, Boston, in an article some years ago, wrote: "Altogether 
the scholarship best entitled to our confidence tells us that Jesus of Nazareth really lived, and that the main outline of His life-story is about as valid history as any record of the past that we possess."

Even Lessing, who is quoted by Professor Eucken as saying that the "accidental truths of history can never become the proof of necessary truths of reason", had enough of common sense to keep steady his philosophical deductions and to make sure the following conclusion: "If Livy and Dionysius and Polybius and Tacitus are so candidly and honourably treated by us, that we do not lay them upon the rack for every syllable, why do we not extend equal liberality to Matthew, Mark, Luke and John?" So Professor George B. Foster of Chicago University, who minimizes the value to the Christian of the historicity of Jesus, quotes a colleague who had a "far better right to a scientific judgement" as saying "that the denial that Jesus ever lived amounts almost to historical insanity."

It seems at first sight somewhat surprising that thinkers in the Christian Church, even teachers and preachers in the orthodox communions, have of late taken the position that the historicity of Jesus is unnecessary even though it be not yet proved that such a person as Jesus never lived and never taught. This kind of argument is not because they are frightened into thinking that the last fortress of Christian apologetic is at last to fall, as because they perceive, what is after all a vital truth, that religious truth and religious faith belong to the essence of religion rather than issue forth from historical facts or from faith in historical facts. One may believe in a fact 
and not be very religious. One may believe in the credibility of the Gospel record concerning Jesus, and yet have but little of the Christ spirit or draw any the nearer to God the all-Holy. Such is the attitude taken as we have seen by Dr. Eucken, as before him by Lessing and Kant. This is far from asserting that Jesus is not an historical person, and that we have no true historical record concerning him. The argument is that even if the historicity of Jesus vanish away under the magic power of these historical critics, we would not lose in consequence our religion, neither should we give up our Christianity. Prof. Benjamin Warfield of Princeton, refers to the Christianity of such a theory ironically as "Christless Christianity".

In China we see how the Buddhists know but little of Sakyamuni, but they are devout in worship of the many Buddahs. Even the Buddha of the Mahayani school, prevalent in China and Japan, is an idea rather than a person. It is a false and dangerous theory to claim that because one knows but little of the founders of a Religion, he is exempt from being virtuous or religious.

Christian Chinese, like all persons of a practical turn of mind, are attracted to Christianity because of the historical facts that lie at the basis, more than by the mystery or abstractness of any doctrine; but it may be well for them as for us all that the spiritual, and mystical aspects of the essence of Christianity are receiving new emphasis, so that truths which come from God, whatever the channel,truths about God and of man's relation to God-may inspire, guide and comfort, even though what were 
once thought facts in history may at last be found to be no facts.

A writer in "The Hibbert Journal," quoted by Professor Warfield, says: "Truth is truth, whether uttered by Sophocles or Plato in Athens, by Hillel or Jesus in Palestine, by Seneca or Aurelius at Rome." And again: "And if, in the inevitable evolution of the not-distant future, Jesus, too, should disappear from the assured certainties of the world, man would not cease to be religious." Professor MacIntosh of Yale in different articles holds clearly that we would not cease to be Christian, because Christ as an historical personage had disappeared, for the simple reason that certain truths called Christian have come down to us from some source in Palestine, or rather from God through some channel, be it Jesus or those who told his story. His own words are: "Whether the 'spring' was a group of Syrian mystics, or, as we have no doubt it was, Jesus of Nazareth, the creative source of this water of life is none other than the very being and activity of God." Again he says: "We should be very far from agreeing that if, for good and sufficiently critical reasons, the historicity of Jesus had to be given up, the deathknell of Christian religious faith would be sounded."

There is no reason for us even to surmise the passing away of Jesus from off the pages of history, but it is well that as an indirect result of historical criticism we learn that the foundation of each one's religion must be within one's self, must be empirical, "must be capable of immediate realization."

In the third place it is apparent from the testi- 
mony of these scholarly and conscientious men of skeptical mind that it is liberal religion as exemplified by Unitarianism which is best able to retain for: religion and for Christianity, the affections and reverence of men who find it hard to believe all the teachings of the Church, but who have the same religious aspirations as the most orthodox of Christians. The orthodox have been all too ready to cast into outer darkness every type of unbeliever, and to a.ssume that the friendship which Unitarianism bears to unbelief involves it in the same catastrophe. It is the liberal Christian who succeeds in winning back the unbeliever, not perhaps to the statements of orthodoxy, but, what is better, to devotion to jesus and obedience to the will of God.

The sentiments expressed by many skeptics concerning the Founder of Christianity approximate the point of view held by liberal religion, and this as much in the large bodies of Christians as the smaller bodies of Unitarians, Universalists and Friends. Thomas Jefferson, Theodore Parker, Prof. John Fiske and Dr. Eucken have all been acknowledged as skeptical, and yet their views about Christ are these commonly spoken of as Unitarian. The particular view that the historicity of Jesus is not the essential thing in the religious life goes even beyong the view of many Unitarians. Unitarianism has been inclined to lay stress on Jesus as a man, and of course as a real man. The skeptics whom we have cited have done the same. Professor George B. Foster, a Baptist, whom we have just referred to, began an address before the American Congress of Religious Liberals with this statement: "Scientific 
theology, together with the spirit and thought of our new age in general, has succeeded in undermining the ecclesiastical dogma of the trinity and of the deity of Christ." In quoting these words I would place the emphasis on "ecclesiastical dogma", for in a very essential way these doctrines may still appeal to the reason.

The Rev. Dr. Rainsford, for many years rector of St. George's Episcopal Church, New York, has lately written: "The world is not tired of Jesus Christ. Christianity as it has been proclaimed by the orthodox churches can no longer hope to win a world-wide influence. . . . Multitudes feel that the real Jesus when he is presented to men, still draws all that is best in the human heart to Himself, still has the power, as no other, to save men. But of ecclesiasticism our age is sick."

Professor D. C. Macintosh, a Congregationalist, says: "The irrationalities of historic Trinitarianism must be removed, but its vital essence must be retained." And then he shows how "Christianity is the religion of the regeneration and sanctification of the individual and of society through the indwelling presence and creative activity of God the Heavenly Father-the Holy Spirit, whose presence and power in the life of Jesus of Nazareth made him the divine Redeemer, the Son and Christ of God."

Dr. Henry Van Dyke, a Presbyterian divine, now American Minister to the Netherlands, refers to "the person of Jesus Christ as the human life of God," and he adds: "This newness of the gospel lies in believing in Him as a real man, in whose sonship the Fatherhood of God is revealed and made

${ }^{*}$ Written in 1915. 
certain to all men." He presents this view of Christ in his very helpful book, "The Gospel for an Age of Doubt," that many doubts may be dissolved, and he expresses his hope that "if it shows one seeker after God how to find Him in the man Christ Jesus, the chief purpose of the book will be accomplished."

Sir Oliver Lodge, of the Church of England, says in his "Man and the Universe": "The Christian God is revealed as the incarnate spirit of humanity, is recognized as a real intrinsic part of God. . . Infinitely patient the Universe has been whilst man has groped his way to this truth; so simple and consoling in one of its aspects, so inconceivable and incredible in another. Dimly and partially it has been seen by all the prophets, and doubtless by many of the pagan saints. It is not likely to be the attribute of any one religion alone; it may be the essence of truth in all terrestrial religions, but it is conspicuously Christian."

And so, too, does the essayist and poet, Richard Watson Gilder sing us the message of Christ's spiritual leadership to a world of sorrow, doubt and strife :

Behold Him now where He comes;

Not the Christ of our subtle creeds, But the light of our hearts, of homes, Of our hopes, our prayers, our needs;

The brother of want and blame,

The lover of women and men,

With a love that puts to shame

All passions of mortal ken." 


\section{CHAPTER IX}

\section{CONCORD AMONGST RELIGIONS AND UNITY OF THE TRUTH}

There are four central words in the topic to be discussed, namely Religion, with which is linked Concord, and Truth, with which is linked Unity. The conclusions formed are based in part on the discussions already given in the special course under the Billings Iectureship, and in part on the various addresses which have been given from week to week for the last few years by representatives of nearly all the great Religions. For six years this Institute has had a perpetual Congress of Religions, and the ideas now advanced are not of sudden growth, but have been gradually moulded into shape. Even now our mind is not altogether clear as to the precise mcaning to be given to certain terms and ideas, and the relation of these ideas to each other. We are, therefore, unable to speak in a dogmatic spirit, which is perhaps of advantage in a proper and useful consideration of such vast concepts as Religion, Truth, Concord and Unity.

In the previous and preliminary discussions of this series, we have given a Christian's appreciation of Confucianism, Taoism, and Buddhism, the three Religions of China, and of Islam and Judaism, or rather of the Jew, as an intensely persistent person in history. We have also had three special studies 
within the Christian Religion, namely, a Protestant's appreciation of the Church of Rome, the Trinitarian's appreciation of the Unitarian, and various Skeptics' appreciation of Jesus Christ. In addition there have been two complementary studies of the inter-relations of nations, the one being Christianity and the Great War, and the other Religion and International Brotherhood. Properly other religions like Brahmanism and Zoroastrianism, and the religions of Greece, Rome, and Egypt, should be studied in any complete consideration of universal concord and unity. Acknowledging this limitation to our study, we yet trust that the datum is sufficient for forming fairly reasonable deductions. We have one advantage over the usual comparative study of $\mathrm{Re}$ ligions, in that, besides this study, we have noted the great dividing distinctions within the Christian Religion, as well as the relations of one nation to another and their attitude to religion in general and Christianity in particular. The possibilities of either concord or unity are measured by these special studies bearing on Christianity apart from the specific inter-relations of all the great Religions of the world. Thus a Christian may be convinced that other Religions will disappear before the advancing power of the Christian Religion, which thereby becomes the Universal and Absolute Religion; but it is as easy to be convinced that all Christians will adopt one form of the Christian Religion be it called Roman Catholic or Protestant, Trinitarian or Unitarian? Is even Christian unity or Church union likely to take place? Where, in a word, is unity to be found? Should unity be unattainable, is it yet pos- 
sible to bring about harmony - harmony amongst all peoples and all Faiths?

Our method of approach to the religious views of others has been that of appreciation rather than of depreciation, of commendation rather than of condemnation. For a comprehensive or accurate understanding of any religious system this method is manifestly insufficient, but as a means for cultivating the spirit of either unity or harmony, there is, in our judgement, no better method within human reach. "If you can't say anything good of another, say nothing," is a common saying in the formation of human friendships. This rule we make applicable to a discussion of each other's religion. Speak not evil, but only speak good, of a man's religious convictions, of his beliefs, and aspirations, and still more of the distinguished spiritual leaders, who have succeeded in establishing the great Religions. "Thinketh no evil," is a part of the supreme virtue of charity. If one thinks no evil of another, he will speak no evil. An old Buddhist maxim reads: "Honour your own faith, but do not look with contempt upon the faith of others." The Bahai movement, which seeks for spiritual unity among all mankind, in injunction to the Bahais, whether Christians or Moslems, says: "They should neither denounce nor antagonize those holding views other than their own." Emerson said tersely: "Always put the best interpretation on a tenet." This, Rev. Ch. W. Wendte, D. D., who has done so much to promote good feeling between all schools of religious thought, in referring to this method of sympathy, says: "This is a better way to bring about the peace 
of the world than battleships, or treaties, or embassies, or presidential letters, and it will eventually lead the peoples of the earth into a common recognition of those fundamental verities of faith and conduct which underlie all the great world-religions and are the universal quest of humanity." Dr. Richard Storrs in his "Divine Origin of Christianity", whilst convinced of the superiority of Christianity, has used these words: "No thoughtful person will speak without tenderness of any ancient religious scheme, which, in the absence of ampler light, has drawn to itself the trust and hope of human souls, and has been their means, however imperfect, for ascending to nearer intercourse with God."

In all these years of religious conferences at the International Institute by adherents of different religious Faiths, we have had only one rule, and that, whilst one is free to expound fully his own Faith, he must refrain from ridicule or denunciation of the Faith of others. In so far as this rule has been observed has harmony prevailed. As another has said, "Appreciativeness will go further toward a desirable Church unity than any possible doctrinal agreement." It certainly is more assured of success in bringing about harmony and friendliness, mutual esteem and helpfulness, between those who think on religious matters conscientiously, and hence differently.

"The white light of the Truth divine

Is broken into many a ray;

'Lo here!' 'Lo here!' the preachers say, And brothers prate of 'mine' and 'thine'. 
But in God's sight it well may be

That all in one may interweave.

Lord, that each ray leads back to Thee

I do believe."

In referring to Religions, we refer to a religious system of teaching, which in the conception of the Chinese means more an organization than a sentiment of the soul. Permeating all these religious systems is however the religious sentiment. Ambrose used the phrase, now quite current, "Religions are many, but religion is one." In the Chinese language the idea of Religion as a teaching is familiar, but not of Religion in the abstract. Reference to that which is inherent in all is indicated by two Chinese words translated "Law and Virtue" or "Truth and Goodness", for in them is contained all that is good and true in relation both to God and man. If one word is used as indicating this universal, pervasive element that word is truth. Hence from the Chinese conception, a Religion is the formal expression of truth, as truth is the expression of God or of God's will. To look for unity, we cannot find it in Religion but in truth, and truth is unified in the one God. Religion comes from truth or an eternal Principle of Law, and this comes from Heaven or God. In so far as all Religions and all truth are traced back to God, and in so far as all men yield themselves to Him, is unity made possible in religion, in truth, and in the human race. Hence it is that we have made as our subject concord amongst Religions, but unity of the truth. Hence it is that it means more to follow the truth than to follow a Religion, and more to follow God to follow 
the truth. Mankind may never be able to unite in a system of Religion, whose teachings, rites, formularies and tenets fall within the grasp of all men's belief, but it does seem possible for mankind to unite in devotion to the truth. Should devotion to the truth fail to unite men, on account of difference in understanding the truth, then the only way to unite all men in their religious make-up is for all to agree to do the will of God, as each one understands God and the will of God. On this all Religions agree and in this agreement the adherents of all Religions can unite. To proclaim God or to proclaim the truth should mean more than to proclaim a Religion.

The teaching of all the great Faiths agrees in tracing all truth back to God, and in requiring that all submit to God. Submission to God is the essential meaning of the term Islam. It is the supreme idea of Judaism. It was the main purpose of Christ and should be made the one cardinal doctrine of the Christian Church, belief in which can bring about Christian unity. It was Tennyson who sang:

"Our little systems have their day, They have their day and cease to be; They are but broken lights of Thee, And Thou, O Lord, art more than they."

The supremacy of God comes ahead of supremacy of truth, for all truth comes from God. The supremacy of truth comes ahead of any Religion, any Church, any creed, for these are only the professed declarations of truth as understood by bodies of men. As complete comprehension of God is impossible, so complete apprehension of truth is impossible. 
Finite beings have only partial revelations of God and partial comprehension of God's truth. Truth ever appears to finite minds in fragments. No one mind is capable of containing all the truth or all of the Infinite. "Now we know in part."

There is unity in truth just as there is unity in God, but there cannot be unity in all men's understanding of truth. There is with men only unity in the one purpose to follow the truth as each one sees it. Man's contact with truth is partly through the intellect and partly through the conscience. The conscience is the mandatory faculty of man. Each man feels himself under compulsion to do what his own conscience, and not the conscience of any one else, enjoins upon him, and the quality of the mandate depends on the content of the understanding, on "the deposit of faith". Each soul, alike illumined by the Spirit of God, is answerable alone to God. Truth as it comes from God is one, but as it percolates through human brains, it becomes diversified. "Every good and perfect gift cometh down from the Father of Lights, with whom there is no variableness neither shadow of turning." So, too, the source of truth is not in any Religion or in any human mind, but in the mind of God. Truth from the God-ward side stands for unity; from the man-ward side it stands for diversity, but withal a beautiful and divine diversity, for man's desire to know the truth is a divine quality, the breathing forth of God's spirit.

"Truth is truth," as another has said, "whether uttered by Sophocles or Plato in Athens, by Hillel or Jesus in Palestine, by Seneca or Aurelius at 
Rome." Truth, too, whether in sacred books or other literature, whether in holy prophets or through ordinary channels, whether in science, in philosophy, in history, or in mysticism, is all truth, and, what is more, it is one. Professor Philip Schaff, at the Chicago Parliament of Religion, said: "God speaks in history and science as well as in the Bible and the Church, and He cannot contradict Himself. Truth is sovereign and must and will prevail over all ignorance, error, and prejudice." The apparent differences in truth are in the different manifestations of truth; they are different rays of the one light; at times they are different colours of the one light. Let us admire the beauty and not forget the unity. In gratitude and great joy let us trace the truth back to Him who is primal Truth, as well as primal Goodness.

It was Lessing who once uttered a wise and very useful saying: "Were God to offer me the choice between the whole truth and the love of the search for it, with the understanding that I shall never find it, I would choose the latter, knowing that Truth is for God alone." There is, however, this confidence, that the more one's spirit is in communion with God's most Infinite Spirit, and the more one searches for the truth, the more of truth will he be able to perceive, and the more of vigour of soul to follow the truth wheresoever it leadeth. It remains for all those who in every land and in all times search for truth and are more and more finding it, to share with each of these precious, spiritual possessions, as loving children of the same Father.

Truth is not a point or even a straight line. It is 
rather like a vast globe. One phase of truth blends with another, and through a multitude of aspects of truth do the infinity and sovereignty of truth reveal themselves. Being in the form of a globe, one part of truth may appear at antipodes to another part. They are not, however, antagonistic, for a more careful review shows that really they, too, blend with each other and form a part of one whole.

To finite minds truth cannot appear in all its completeness or comprehensiveness, for truth in its totality is infinite. Each one sees a fragment of truth. This fragmentary character of one's perception of truth, whilst unavoidable, becomes error, when it is represented to one's own consciousness as the complete truth, rather than the fragmentary truth. The character of truth as opposed to error is to hold to the due proportion of each form and fragment of truth, conscious of his necessary limitations, is humble rather than proud, tolerant rather than bigoted, teachable rather than dogmatic.

The unity of truth and the universality of God's love reveal themselves in every human soul. This is the essential teaching of Christ and the attractiveness of his teaching. It is the thought of all the great religious teachers amongst all peoples. There is a "Light that lighteth every man coming into the world." St. Peter said: "Of a truth I perceive that God is no respecter of persons, but in every nation he that feareth him and worketh righteousness is accepted with him." St. Paul in Athens used these words: "God that made the world and all things therein, He, being Lord of heaven and earth, dwelleth not in temples made with hands, neither is $\mathrm{He}$ 
served by men's hands as though $\mathrm{He}$ needed anything, seeing He himself giveth to all life and breath and all things; and $\mathrm{He}$ made of one blood every nation of men to dwell on all the face of the earth, having determined their appointed seasons and the bounds of their habitation, that they should seek the Lord, if haply they might feel after Him and find him, though $\mathrm{He}$ be not far from every one of us, for in Him we live and move and have our being." The great Confucian philosopher of the Sung dynasty, $\mathrm{Chu} \mathrm{Fu}$ Tsze expressed the truth in a few words: "All nature and all men are endowed from Heaven with an inner Law," the implication being that truth is imparted to all.

Truth, which stands for unity and perfection, as it issues forth from the Spirit of God, presents diversity and imperfection as shewn forth in the spirit of man. No two persons see truth exactly alike. It is the good fortune of humanity that here and there through the ages God has raised up chosen men of pure spirit and lofty ideal and moral earnestness, who have received a large revelation of truth and passed it on to others-the spiritual leaders of humanity. Such men are the founders or expounders of the great Religions, and the same diversity, which is seen in men's comprehension of truth, is even more conspicuous in the comparison of these Religions. The question becomes accute as to whether the Religions of the world can attain to unity, or whether all that we may expect is harmony, friendliness, concord, between these various Religions. This is the problem more difficult than that of the unity of the truth. As we pass from a consid- 
eration of truth to that of Religion, we quote the words of James Russell Lowell:

"God sends His teachers unto every age, To every clime, and every race of men, With revelations fitted to their growth And shape of mind, nor gives the realm of Truth Into the selfish rule of one sole race:

Therefore each form of worship that hath swayed The life of man, and given it to grasp The master-key of knowledge, reverence, Enfolds some germs of goodness and of right; Else never had the eager soul, which loathes The slothful down of pampered ignorance, Found in it even a moment's fitful rest."

Having considered the supremacy of Truth and its bearings on Unity, it is now possible to make a logical advance to a consideration of the World's great Religions and their bearings on Concord, should unity in their case be found impossible. The law of truth should be made the law governing every Religion and the principles concerning the origin and nature and effect of truth should be applied to these Religions.

If all truth has come from God, the one Source of all, that is, in both the material and spiritual world, then every Religion, which is a wide-reaching exponent of truth, must be traced back to God, to whom be all the glory. Let us not give credit to the Evil One for producing and inspiring so many systems of spiritual aspiration. Let us give our thanks to a loving and wise God. It was Clement of Alexandria who in the early Christian Church wrote these 
words of an advanced theology: "It is clear that the same God to whom we owe the Old and New Testaments, gave also to the Greeks their Greek philosophy, by which the Almighty is glorified amongst the Greeks."

If truth has been bestowed on all men, then it is only reasonable to hold that all Religions and their spiritual-minded founders have also been the depositors of truth. That ordinary men in our own day have consciences distinguishing right and wrong, and have intuitively as well as by tradition a knowledge of the truth, but that men like Zoroaster, Sakyamuni, Confucius, and Muhammad dwelt in the darkness of error and superstition, and that the Religions which they developed were all wrong and must perish from amongst men, is far from the thought of non-Christian thinkers, even if here and there a Christian has been brave enough to profess the creed. Prof. Max Müller rightly says: "We need not be frightened if we discover traces of truth, traces even of Christian truth, amongst the sages and lawgivers of other nations. It shows a want of faith in God, and in his inscrutable wisdom in the government of the world, if we think we ought to condemn all ancient forms of faith except the religion of the Jews. . . . If we want to understand the religion of antiquity, we must try, as well as we can, to enter into the religious, moral, and political atmosphere of the ancient world."

Truth that enters into religion is the highest of all truth; religious truth is more natural to man, more his rightful prerogative, than scientific truth. The latter is acquired; the former, like genius, is 
born. Professor Upton in his "Basis of Religious Belief" says: "It follows that there is a certain selfrevelation of the Eternal and Infinite One to the finite soul, and therefore an indestructible basis for religious ideas and religious beliefs, as distinguished from what is called scientific knowledge."

Dr. James Freeman Clarke, who, whilst referring to "the heathen religions", yet speaks of them in a respectful spirit in his "Ten Great Religions": "They must contain more truth than error, and must have been on the whole, useful to mankind. We do not believe that they originated in human fraud, that their essence is superstition, that there is more falsehood than truth in their doctrines, that their moral tendency is mainly injurious, or that they continually degenerate into greater evil."

A still more important truth, already outlined in these lectures, is that of God's presence. If, then, God is present in nature, in beauty, in history, in philosophy, in science, surely we must agree that $\mathrm{He}$ is present in man's moral and religious nature, and still more in the moral and religious reformers and teachers of the world, and in the teachings which they have transmitted to coming generations.

"The Unseen Power, whose eye

Forever doth accompany mankind, Hath looked on no religion scornfully That man did ever find."

As Dr. Hunter has beautifully expressed it: "We dare not pretend to limit the ways by which $\mathrm{He}$ makes known His personality and His presence, and moves, illuminates, and guides His children. He 
draws nigh to them, not only in and through His creation and the course of history, not only through the teaching and example of His great prophets, holy servants, and beloved sons, but immediately, mind with mind, spirit with spirit." This thought elevates humanity and the Religions of all the nations of the world. Because of God's presence Christianity assumes its high place in the affections and adoration of men, and other Faiths, the fruitage of God's good wisdom in caring for His children, should not be excluded from the honour of men, any more than they are excluded from the favour of God.

As men may have a different understanding and interpretation of the truth, so religious truth as taught by prophets and sages in the great Religions will also present aspects and be viewed and interpreted by them in different ways. Different Religions, and especially different schools of thought within the same Religion, lay emphasis on different phases of one universal truth and therein the world derives a benefit. Looked at in this light, these Religions, like individuals, should learn from each other. The truth of one should pass on to others. Exclusiveness should disappear. Surely if men of the East and the West can be teachers to each other, their teachings ought to include that which is supreme, man's spiritual relation to the Unseen but ever-present spirit. I am willing to learn from other faiths and I sincerely hope that they in turn may receive the inspiration and vitality, the comfort and peace, which Christian truths import.

I have been growing impressed with two facts as to the way God's truth has gained admission to hu- 
man hearts and been incorporated in the religious Faiths of past centuries amongst all peoples. The one is that knowledge of spiritual truth is in proportion to one's observance of the will of God, however that will is made known. Christ stated it thus: "If any man will do His will, he shall know of the doctrine, whether it be of God." The second fact is that the best of any Religion is found in the original expounders of these Religions, men who had a vision of the Unseen, whose hearts were moved by holy impulse, and who laboured strenuously for the regeneration of society. We may not only say, "Back to Christ", but, "Back to the Buddha, back to Lao Tsze, back to Confucius and Mencius, and back to the holy men, who had gone before." When we take the teachings of the first men in the line of spiritual genealogy, we see how near these men and their thoughts were to each other. It is here that anything like approach to unity amongst the Religions can be found. As the Christianity of Christ is better than the Christianity of any Christian, so the Taoism of Lao Tsze is better than the Taoism of any Taoist. The original sources are therefore the best.

In speaking of truth as embodied in a Religion, we need to bear in mind that spiritual truth, being with all truth the breathing forth of God's spirit, is of different quality from truth elsewhere in the universe. A man may be versed in science, and yet be blind to the things of the spirit. The Rev. Henry C. Minton puts the matter in the following clear language: "It is folly to try to weigh truth (i. e., spiritual truth) in an apothecary's scales or to 
measure it with a carpenter's rule. It would hardly be venturing very far to say that the heart has not much to do in assenting to a geometrical theorem or accepting a chemical formula. It is a great mistake to imagine that Christianity is any less rational because its teachings are not mathematical demonstrations." We may add that it is right to expect that the reason must be satisfied with any truth, before it can really be believed, but it is also evident that moral qualities have a profound bearing both on reason's grasp of the truth and on the belief that comes after.

In tracing back the best of any Faith to its origin, it seems as if we were running contrary to the law of development. Our thought is that any particular Religion will find it hard to advance beyond the supreme personality, who started the Religion on its course, but religion as a universal factor in all history and pervasive of every form of Religion is subject to development and to increase in the appreciation of men. We know more today of God's doings in the world than the ancestors of our Faith knew; it is not so certain whether we are better than they.

Professor Max Müller, speaking of the good old days, what we in China are wont to call the Golden Age of Yao and Shun, says: "It is but seldom borne in mind that without constant reformation, $i$. e., without a constant return to its fountain-head, every religion, even the most perfect, nay the most perfect on account of its very perfection, more even than others, suffers from its contact with the world, as the purest air suffers from the mere fact of its being breathed. The founders of the ancient Religions of 
the world, as we can judge, were minds of a high stamp, full of noble aspirations, yearning for truth, devoted to the welfare of their neighbours, examples of purity and unselfishness. . . . If we find that the Christianity of the nineteenth century does not win as many hearts in India and China as it ought, let us remember that it was the Christianity of the first century in all its dogmatic simplicity, but with its overpowering love of God and man, that conquered the world and superseded religion and philosophies, more difficult to conquer than the religions and philosophical systems of Hindus and Buddhists."

Along with this reverence for God-given leaders of the past, there certainly exists a hope for better days still to come and a belief in the principle of progress. Men look forward to an Absolute Religion to dominate humanity, the kingdom of God in its fulfilment. Of this we will speak more later on, but meanwhile quote the words of the apostle of liberalism, Theodore Parker, from his "Discourse of Religions": "No one teacher, or form of Religion, nor all teachers and forms put together, have exhausted the religious sentiment, which is the groundwork and standard measure of them all, and is represented more or less partially in each; and so new teachers and new forms of Religion are always possible and necessary, until a form is discovered, which embraces all the facts thereof, and thus represents the Absolute Religion, as it is implied in the facts of man's nature or the Ideas of God. . . . Its temple is all space; its shrine the good heart; its creed all truth; its Ritual works of love and utility; 
its Profession of Faith a divine life, works without, faith within, love of God and man."

A correct measurement of each Religion must take into account that error, even if absent at the beginning, according to the claim of each Religion, has since crept in to corrupt and dishonour the purity and glory of the past. For this reason we recommend that we judge each Religion not only by its best elements but by the noble start which it received. Thus Professor Max Müller adds these words to what we have already quoted: "If there is one thing which a comparative study of religions places in the clearest light, it is the inevitable decay to which every Religion is exposed."

In returning to the utterances of the speciallyendowed exponents of religious truth in the past, we draw near to the fountain of life, to the essence of power. In things essential we attain both to truth and to unity. Things extraneous and things erroneous drop away into oblivion. Christianity as seen today, in every branch of the Christian Church, is not a model, an ideal, the Absolute or the Ultimate. And thus, too, must adherents of all the Faiths regretfully acknowledge that today at least truth is mixed with error, and the day of perfection has not yet dawned. Professor Charles Cuthbert Hall, in his illuminating lectures, "Christ and the Eastern Soul", urges in many ways that attention be given to the elements of "imperishable and universal essence" which Christianity contains, and he adds: "It is here, and only here, that we can be said to enter the spiritual temple of this Faith. Ecclesiastical systems, forms of worship, official dis- 
tinctions, are occasional, variable, partial, often transitory modes of expression; inadequate yet necessary attempts to give utterance to that which in its completeness transcends utterance." This thought only needs to go beyond the sphere of the Christian Religion to all the Religions, that we may the better recognize the insufficiency of any particular Religion and the sufficiency of the underlying principles of all Religions. If Christian denominations acknowledge their incompleteness, then the Christian Religion as a whole, along with the other religious systems, as organized and exhibited in the world, may safely confess to the same imperfection.

Professor George William Knox finds unity and agreement, not so much in the "developed contents", as in the "vague and primary feeling", belonging to the nature of man. He says: "Through all forms, henotheistic, monotheistic, pantheistic, the religious element remains, but varies, is impoverished or enriched, ennobled or debased according to man's stage of culture and his general view of the world."

In going back to the essence of religion within all Religions, and to these primary feelings of the human soul, we approach to truth which already we have represented as a sublime unity.

Neither does the modern scholar speak of true and false Religion. Even so great a man as Sir W. Monier Williams has described Brahmanism, Buddhism, and Islam as the "three chief false religions." Rather, every Religion is seen to possess the truth, and truth, moreover, as it came forth from the heart of Infinite love.

Neither are we so accustomed as men in the past 
to speak of a natural and a revealed Religion, for every Religion, a marvel in the spiritual sphere, is not the product of man's own devising, but reveals to a greater or smaller degree the mind of God. Dr. Richard Storrs thus says: "Christianity is but one amongst many religions, in claiming Divine authorship for itself, with a co-relative Divine authority over the hearts and minds which it reaches." No religion is really the outcome of what Dr. Storrs calls, "the native religious sentiment of man", but God's voice speaks through these Religions as through the consciences of men.

In China each Religion is accustomed to speak of itself as orthodox and of others as heretical. It is not for Christianity to join in with these self-exalted claims, but rather to regard the way of the Lord as right, and human ways when contrary to God's way as wrong.

Others have distinguished the Religion of the Bible and of all others, but as Professor Henry S. Nash has said, "The old schemes which hinged on a fixed distinction between the Religion of the Bible and all Religions outside the pale of Biblical revelation, succeeded by dint of excluding a large part of the phenomena."

Even the distinction of a universal religion, as is claimed for Christianity, and the ethnic religions, is not altogether satisfactory, for as yet even Christianity has not gained a hold on all races, whilst the adaptation of other religions to particular nations and races does not imply that their truths are not suited to others. Rather, the underlying principles of all Religions, that which forms what Professor 
Charles Cuthbert Hall calls "the content of the common essence", are universal in their application and of universal obligation to be observed. In "Hiawatha", we are asked to listen to "this Indian Legend":

"Ye whose hearts are fresh and simple,

Who have faith in God and Nature,

Who believe, that in all ages

Every human heart is human,

That in even savage bosoms

There are longings, yearnings, strivings

For the good they comprehend not,

That the feeble hands and helpless,

Groping blindly in the darkness,

Touch God's right hand in that darkness

And are lifted up and strengthened."

I can do no better in giving expression to such views on Christianity and other Religions than to quote from a magnificent sermon of Dr. John Hunter of Glasgow delivered in Boston in 1907 before the Fourth International Congress of Religious Liberals. I quote largely as follows:-

"We interpret, and rightly interpret, the various religions of mankind as man seeking God; but they may also be regarded, and rightly regarded, as God seeking man. 'Unaided reason', men have been in the way of exclaiming, as they contemplated the various religious systems of the world outside the Hebrew and the Christian religions. But we may well ask, with Cardinal Newman, whether the reason of man is ever unaided. There are not two kinds of religion, natural and revealed. From the point of view of human capacity and seeking and 
effort all religion is natural: from the point of view of divine manifestation all religion is revealed. The Logos doctrine of the Fourth Gospel, whatever else it teaches, teaches the divine activity in our world from the beginning. It would be an error to suppose that God neglected the larger part of mankind because of His more intimate dealings with one section of the human race. It must be true, if God be one and His name one, that men of like passions and needs as ourselves, who came from God and belong to God, and are nourished physically by His air and sunshine and fruits of the earth, must also have provision made in the divine order of things for the sustenance of their spiritual life, and that it is not left entirely to the tender mercies of their fellows whether they shall have God or be without God in the world. It must be true that God cares equally for the souls of all His children, and that $\mathrm{He}$ finds access to them, helps them, teaches them, comforts them, saves them, by methods and means that are not seen and temporal, and by ways in which no man can tell whence $\mathrm{He}$ cometh and whither $\mathrm{He}$ goeth, and that $\mathrm{He}$ is only limited in the giving of Himself to them by their capacity to respond and receive. People of old used to think that the divine action was confined to here and there, now and then; but the conviction is growing and spreading that the only defensible conception of the moral action of God on humanity is that of a continuous and impartial influence, limited to no age or race.

"To our enlightened feeling it is becoming more and more presumptious to say that His spirit can only work along one line of human thought, or can 
only bring men to Himself through one set of defined successions of emotion or experience. Personal intimacy with God is not an experience special to Jews or Christians. A truer and larger faith in God as the everlasting Father and Teacher and Saviour of Mankind has made it no longer possible for intelligent and believing men to regard all religions outside the Jewish and Christian pale as superstition and falsehood, or to keep up the old pitying and condescending attitude towards them. Their immaturities and corruptions we no longer allow to cheat us of the right to say, 'God is good to all: whither shall we go from His spirit?' He has never left Himself without a witness, never left multitudes of His creatures without His help, without light and guidance, without comfort and salvation.

"There is no want of revelation. There is, indeed, nothing but revelation. From the beginning God has been revealing Himself to men by the order and beauty and bounty of the world, through the natural affections, by the teaching and learning of life and the education of history. Knowledge of nature and man is knowledge of God. In finding order, harmony, bounty, beauty, truth, wisdom, justice, goodness, and love, God is found. It is all revelation from nature to man and from man to highest man."

The best way for adherents of different Religions to appreciate each other, as a matter of sober sense and not mere emotional good-nature, is to recognize the points of agreement. In October of 1912, at one of our largest religious conferences, with the Taoist Pope in the chair, I pointed out eight fundamental 
principles common to all the great Faiths. These were exhortation to do right, training of one's own character in righteousness, helping others to do right, recognition of a Supreme Being, belief in retribution, belief in a future life, in some cases immortality, the duty of repentance, and the desire for salvation. To these, so far as the Religions of China are concerned, we should add love, as the greatest thing in the world, as "the bond of perfectness". In different aspects this quality of love is made known and spoken of in the teachings of the different Faiths. In Confucianism it is fraternity, in Buddhism compassion, in Taoism gentleness, in Islam charity, and in Judaism and Christianity it is brotherly-kindness. The last three Religions, revering the same patriarchs and prophets, teach the more important truth of God's love, sometimes spoken of as mercy and sometimes as grace.

The appreciations already given of different Religions and schools of thought show in each case a still wider correspondence. In recognition of this common basis of all Faiths-forms of infinite truththese Faiths are able to arrive at unity. Even whilst there is not one Religion, owing to minor factors taking the place of primary principles, there is a oneness in the religious substratum of all Religions.

The American preacher, the Rev. James I. Vance, cites just three elements to the common essence of religion, speaking in the following language:

"Views of religion are one thing, and the fundamentals of religion are another. Views come and go, but the fundamentals are essential to religious existence. They may be summed up in three statements 
-1. Belief in a personal God. 2. Belief in a conscious immortality. 3. The effect of this belief on character and conduct. These constitute the essence of religion. They are not the affairs of an epoch, nor peculiar to any stage of civilization. They are timeless facts and invest religion with an everlasting reality."

Unity in religion, as unity amongst all the Religions, comes through emphasis of the unities rather than of the differences. Men come to agree with each other, when they think of the points of agreement and pass by the points of disagreement.

It is well, however, that the whole world is not all oneness without chance for variety. If the great Religions were at one in everything, there would be uniformity, which is only unity without vitality. Only that much of agreement is needed which can attain to unity without destroying the life. If Christian sects have learned that each is needed in the fuller manifestation of Christianity, then we may go one step further and acknowledge the utility of every Religion in the fuller manifestation of the common religious sentiments which find their centre in God. The blind preacher of Scotland, the man of deep devotion, the Rev. George Matheson, has beautifully expressed the thought in the following poem:

"Gather us in, Thou Love that fillest all!

Gather our rival faiths within Thy fold!

Rend each man's temple veil and bid it fall,

That we may know that Thou hast been of old; Gather us in! 
"Gather us in! we worship only Thee;

In varied names we stretch a common hand:

In diverse forms a common soul we see;

In many ships we seek one spirit-land;

Gather us in!

"Each sees one colour of Thy rainbow light, Each looks upon one tint and calls it heaven; Thou art the fullness of our partial sight; We are not perfect till we find the seven;

Gather us in!

"Thine is the mystic light great India craves,

Thine is the Parsee's sin-destroying beam, Thine is the Buddhist's rest from tossing waves, Thine is the empire of vast China's dream;

Gather us in!

"Thine is the Roman's strength without his pride, Thine is the Greek's glad world without its graves,

Thine is Judea's law with love beside, The truth that centres and the grace that saves; Gather us in!

"Some seek a Father in the heavens above, Some ask a human image to adore, Some crave a spirit vast as life and love: Within Thy mansions we shall have all and more; Gather us in!

This poem bears the title "One in Christ," and his biographer, another Scotch Presbyterian, adds: "It was his aim to stand on a platform so broad that he could find room on it for every one, whether Pagan or Christian, who was struggling towards the light. Such a method does not lop off what 
may seem incongruous, or irreconcilable, in the different forms of Faith which it unifies. It, on the contrary, gathers them together as they are; and the central truth, linked to Him who is the Truth, of its own accord sheds what is defective, and receives new strength and life from Him to whom it is joined."

The open-minded student of comparative religion will be quick to see that these agreements in religious belief and aspiration, in life and duty, concern the very essence of religion, and not the phenomena, still less the excrescences, of religion. They are the inner light, which shines forth in human activities. They are the soul of truth in the outward frame of mixed good and evil. They are God's life-giving and spiritual energy which differentiates itself into the vast variety of finite existences.

Agreements are fundamental, not superficial. They touch truth, not fancy. They are eternal; they are universal. Being so, they are, as Professor Charles Cuthbert Hall has said, in his "Universal Elements of the Christian Religion," "self-evidencing." "They rise in self-evidencing authority to command the homage of the moral reason, as amongst the things that cannot be shaken." The Christian realizes that, whatever be his particular branch of the Christian Church, there are these fundamental and self-evidencing elements in the Christian faith, "constituting a common essence." It is for this reason that he accepts and cherishes the Faith as embodied in Christ. It is for the same reason that he and others should equally and as readily accept and cherish the "common essence," 
"the self-evidencing truth," which all Religions possess. A truth has no vitality, if one accepts it on another's authority, but fails to see it as truth in his own consciousness.

It is just as important that we recognize that beyond the unities, there are the harmonies, and beyond agreements there is the need of mutual goodwill. In many ways the teachings of all Religions agree; but even when agreement is impossible, and even because of this very lack of agreement, there is scope and need for concord. A famous saying of Confucius is: "The Princely Man wants men to be in harmony, but not to be alike; the Small Man wants men to be alike, but not to be in harmony." To say, as is often said in China, that all religions are the same, is just as wrong as to say that they are not the same. They are all alike and unlike. It is when they are unlike that there is need to cultivate harmony. Two men, very much unlike in tastes and appearances, may yet be good friends. So the great Faiths should not antagonize each other, but befriend each other. "The good of God's purpose is not a discord but a harmony."

A sentence much used is the following: "In essentials unity, in non-essentials liberty, in all things charity." This is generally spoken of concerning the many branches of the Christian Church, but the rule applies just as well to the inter-relations of all forms of religious belief.

Treaties and laws speak of "religious toleration." Better than toleration are sympathy and appreciation, the one the act of the heart and the other of the intellect. The two are akin to charity, as toleration is to liberty, and as points of agreement, 
which concern the "common essence," are akin to unity. Another has well said: Naturally, we love our own best: we believe our own faith to be the highest possible, or we should not hold it but we must be appreciative and sympathetic to the spiritual strivings of others who are no less sincere than we endeavour to be." With such a spirit mutual recriminations, slurs, odium theologicum, polemical bitterness, all the wranglings of divinity schools, and the many kinds of ecclesiastical differentiations, melt away under the radiance of a broad charity, "rejoicing not in iniquity, but rejoicing in the truth."

The way to agree is to agree, but suppose real agreement is impossible! Then comes in the harder task of cultivating charity and concord. Harmony is just as easy of cultivation as any of the graces, and just as easy in religion as in music-or perhaps we should say, just as difficult.

The first way to bring the adherents of different Faiths near to each other in true sympathy and beautiful accord is to keep always before the mind how great is the agreement and unity in all the elements of an imperishable and universal essence comprised in all Religions.

A second way to bring about harmony is to realize that, whatever the difference of intellectual conception of truth or of its interpretation, others as well as ourselves are sincere in the purpose to do the right and commit one's self to the sway of the truth. Persons who are honest and sincere can be good friends, though of different Faiths. To be sincere is to be true and this is the basis of human 
friendship: thus the Chinese teach. Dr. George Matheson in his great work "The Distinctive Messages of the Old Religions," declares that the right attitude of Christians to other Faiths is that of reconciliation. Speaking of the mission of Christianity he says: "She has not sought to derogate from the doctrines of antiquity; she has only sought to diminish their antagonisms. China may keep her materialism, and India may retain her mysticism; Rome may grasp her strength, and Greece may nurse her beauty; Persia may tell of the opposition to God's power, and Egypt may sing of His pre-eminence even amidst the tombs; but for each and all there is a seat in the Christian Pantheon, and a justification in the light of the manifold wis. dom of God."

St. Peter used these remarkable words, "Ye have purified your souls in obeying the truth," and Dr. Charles Cuthbert Hall referring to this great thought correctly says: "So long as religious conceptions are held or preached with a view to maintaining orthodoxy, the anxiety to receive official sanction may gradually undermine intellectual and moral sincerity, and must surely destroy the vivacity and courage that are brought to the soul by its commitment to truth that has been investigated at first hand and certified by direct experience."

In the third place, all humanity can draw near to each other in friendly accord, if they but realize the wide prevalence of the upward look, the instinct after God. A distinguished scholar of India has said: "Religious life is only possible when one gets to the centre of life, which is God Himself." This 
drawing nigh to God, this feeling after God, is the quality of the soul that attracts others to itself. We should be very sympathetic, when we see in others a response to the cry of one's own soul. Men's emotions, more than men's keenness of intellect, men's desires and aspirations, what we call sentiment, hard to define and incapable of being bound in anything iron-clad,- - these are really the essential constant of all forms of religious worship. They are not the exclusive and distinctive mark of any one Religion, but they belong to all Religions. There is here more than affinity of belief or opinion; there is kinship of feeling. The heart, moved upon by the Spirit of God, accomplishes where the brain fails, in cementing human friendships, in furthering universal brotherhood, and in bringing humanity into atonement with God. It was Tertullian who said: "Testimonies of the soul to God are as true as they are simple, as simple as they are universal, as universal as they are natural, as natural as they are divine." It was Archbishop Tillotson who stated the truth thus: "God hath wrought the image of himself upon the mind of men, and so woven it into the very frame of his being, that, like Phidias' picture in Minerva's shield, it can never totally be defaced, without the ruin of human nature."

My own father in "Voices of the Soul Answered in God," uses the following language: "Man cannot be understood without God. Possibly God cannot be understood without man. When God made the soul, he made it to turn instinctively toward himself. Hence all created spirits are so many distinct prayers, and God is their answer." 
A fourth bond of fellowship, in fact a bond of union, is in the determination to do the will of God. This is more than to follow the truth. Christ made this the chief aim of his life and enjoined on his disciples to do the same. "I promised to do whatever God requireth of me, trusting in His promised grace to help me." This is a creed not only for the Christian but for all men. He who declares this creed should be given the hand of Christian fellowship.

In the fifth place, he who knows of Christ and is willing to follow Him, and he knows not Christ, but is heeding the Universal Logos of God, should also be received as brother and friend. "Follow me," was Christ's command, and Christ did not measure the devotion of His followers by any intellectual apprehension of his nature or of his mysterious relation to God. To be able to give a definition of Christ, acceptable to the rigidly orthodox, is not so great an achievement in religion as to secure an imitation of Christ, the goal for all, about which no dispute need arise.

Amongst the Church Fathers, Justin Martyr in his "Apology" refers specially to the teachings of the Logos, "of which mankind are all partakers," and then adds: "They who have made or make the Logos the rule of their actions are Christians." Again quoting from Dr. Hall, we have these words as to the thought of Christ in Christianizing the world: "It means to make disciples for Him of all the nations-not disciples of the Church, converts to certain schools of theological opinion."

In the sixth place, there is both union and con- 
cord amongst all who, in any land or in any Faith, are cultivating the religious spirit. I have often felt in China more drawn to some quiet, spiritual-minded Taoist than to the cold dogmatism of some of the Christian brethern. The religious spirit means far more than religious doctrines. Universal religion, $i . e$. the universal religious sentiment, is not so much theological as biological. Religion is a matter of life rather than of logic. Dr. Minton, speaking of Christianity, as I would speak of religion in general, says: "It is not a system of truth only. Theology is not all of Christianity, any more than anatomy is all of physiology."

President Frederick W. Hamilton concisely expresses it thus: "Religion as a sentiment and an emotion is the fundamental constant belonging to all forms of Religion. It is essentially the same everywhere." Dr. William E. Channing, thinking of these harmonies of which we have made mention, has said: "Inward sanctity, pure love, disinterested attachment to God and man, obedience of heart and life, sincere excellence of character, this is the one thing needful, this is the essential thing in religion."

In the seventh place, all who lay stress on a good life should be able to co-operate harmoniously for the uplift of humanity. The New Testament, which never makes mention of Religion as we are accustomed to use it, in meaning a system of religious truth, tells us through the Apostle James what was understood by the term "religion" in those days: "Pure religion and undefiled before God and the Father is this: to visit the fatherless and widows in their affliction, and to keep himself 
unspotted from the world." According to this, religion, which is the substratum or essence of each of the Religions, means kindness or compassion, and purity or singleness of religious aim.

Every Religion has good right to magnify its early teachers and teachings, but in the end they will be judged by their ability to make good men and women today. This unity of aim is always and everywhere one of the harmonies in religion. It was Dr. Illingworth who wrote: "The Christian Religion is one phenomenon, a totality, a whole, of which the New Testament is only a part. We of today are in actual contact with a living Christianity which has persisted through nineteen centuries of chance and change." In fact, men give approval to the Church, the Religion, the priest, who actually succeeds in transforming society. The mere claim that one's Religion is divine in origin, or the greater claim that it is exclusively so, will not avail with practical men the world over. Dr. James Freeman Clarke, speaking of other Religions, and not so much of Christianity, says: "Unless they contained more of good than evil, they could not have kept their place." This persistency of the world's great Religions forbids us from a sweeping condemnation of other teachers in religious problems. At the same time the duty to live a good life warns all, Christian as much as non-Christian, and non-Christian as much as Christian, that by decline in goodness the Religion in which one believes is destined to destruction and cannot by any possibility hope for universal spiritual conquest. "I have a settled faith," said Dr. Hall to his Indian audience, "that 
whatever is true and essential to the fullness of truth must forever abide under whatever name or Religion it has come into being, and whatever is not essential to the truth will, in the end, when it has done its work, be permitted to withdraw and pass away."

These seven elements of religious harmony are so near to unity, to agreement, that it is perhaps hard to distinguish unity of the truth from mere concord amongst all the Religions. Certainly as concord amongst the different Religions expands, it is gradually transformed into the unity of the truth. "In essentials unity", still remains the law of the universe. Points of agreement and elements of harmony within all the Religions are concerned with essential truths, and, so far, stand for unityunity in religion-because a unity of the truth. In the words of Professor Max Müller, "To those, no doubt, who value the tenets of their Religion as the miser values his pearls and precious stones, thinking their value lessened if pearls and stones of the same kind are found in other parts of the world, the Science of Religion will bring many a rude shock; but to the true believer, truth, wherever it appears, is welcome, nor will any doctrine seem the less true or the less precious, because it was seen, not only by Moses and Christ, but likewise by Buddha or Lao Tsze."

We thus reach the point that religious unity as unity of the truth-in other words, unity in essential truths-is to be sought for, as something possible, but that anything more than concord between great religious systems and their various adherents 
is probably never to be expected. Whilst Christian unity, for example, is to be our hope and prayera unity in the underlying truths of Christianity, is it at all likely that the different branches of the Christian Church-what others regard as different forms of the Christian Religion-will ever unite in one system, one Church, one Religion? How, then, can the Christian Religion, thus viewed as a system of teaching and an organization, just as we view the other Religions, ever become the Universal Religion or be classed as the Absolute Religion? To be sure, if by the Christian Religion we mean only the inner soul of Religion, the vital and imperishable truths enunciated by Christ and lived out in His life, then we may hope that for Christianity there will come both unity and universality and that Christian Truth will finally prevail. We may also hope that the fundamental truths of all the Religions, truths emanating, as we have argued, from the one God, will likewise attain to unity of belief and universality of domination. But this is something very different from claiming for any outward form of Religion, $i$. $e$. for any particular Religion (religion with a capital R.) ultimate universality. Truth is absolute, imperishable, and may become in humanity, as already in God, one and universal; the truths contained within all the Religions, whether the Christian Religion or not, may be viewed in exactly the same way and attain to the same result. Thus there is exclusiveness for truth, or, we may say, for religion, if by this is meant the common religious sentiment, but not for any particular Religion. "Religion," says Professor Euc- 
ken, "will surely come to new ascendancy,-but the return to religion by no means signifies a return to the old forms of religion." The Christian may well cherish the thought that Christ is the Truth, but even Christ never taught that all others had no truth. He never limited truth to Himself alone.

As within the Christian Religion there is a place for different communions or sects, which should never degenerate into sectarian bigotry and discord, but should work lovingly and harmoniously together, so in the larger sense, and with just as much reason, the various divisions of the universal religious sentiment should avoid wrangling, rivalry, and persecution, and should combine in the spirit of harmony, in the characteristic of charity, and in the bonds of peace.

It was the spiritual thinker of India, Keshub Chunder Sen, who expressed this hope: "The time is coming when the more liberal of the Catholic and Protestant branches of Christ's Church will advance and meet upon a common platform and form a broad Christian community in which all shall be identified, in spite of all diversities and differences in non-essential matters of faith. So shall the Baptists and Methodists, Trinitarian and Unitarian, the Ritualist and Evangelical, all unite in a broad and unversal religious organization, loving, honouring, serving the common body, whilst retaining the peculiarities of each sect."

With the growth of harmony amongst the many Christian communions, these communions become more and more synthetic in their relations to each other. Why should we fear the synthetic amongst 
all the Religions? If each has truth, why should the other dread to accept it? If each has goodness, why should it refuse to impart that goodness to others? Why should any Religion, even the Christian Religion, be exclusive rather than inclusive? Why attempt to draw lines in the open and infinite space of God's infinite love?

\section{"For the love of God is broader Than the measure of man's mind, And the heart of the Eternal Is most wonderfully kind."}

China presented the greatest example of the synthetic spirit in religion. The Chinese, unless they be priests, belong to no one religion, but accept truths and teachings, rites and tenets, from all three, and no doubt much of the religious thought of the nation has also been derived from Judaism, Christianity, and Islam. The three great Religions of China are not in any sense mutually exclusive. "The three," as Mr. Soothill has said, "are complementary rather than antagonistic to each other, and together they make a fuller provision for human needs than any one of them does separately." Thus the story is told of the scholar of the sixth century, Fu Hsi, that he was wont to wear a Taoist cap, a Buddhist scarf, and Confucian shoes. An old saying is this: "Three Religions, one organism; nine streams, one spring; one hundred schools, one principle; ten thousand methods, one rule."

The Japanese have the same happy combination of Shintoism, Buddhism, and Confucianism. It is hence hard for them as for the Chinese to see why 
they should become exclusive in becoming Christian. Count Okuma, when asked what would be the future religion of Japan, replied, "Frankly, I do not know what it will be. Perhaps it may contain a mixture of all the Religions; probably not Christianity in its Western form. We need the social side of Christianity in Japan, your neighborly and philanthropic characteristics. We do not understand nor do we care for your theology."

Schiller, in his drama of "Nathan the Wise", shows how Saladin the Moslem, Richard the Christian, and Nathan the Jew are changed from mutual suspicion into mutual affection and a common faith. In the same drama he tells how a man of the East bequeathed a ring to his favorite son, who would be "beloved by God and men," and how, when the ring was passed down to one of his descendants who had three sons equally beloved, the father had two other rings made, just like the original, and when the three sought to find out which was the original ring, the ring of promise, the father said: "The true gem, you say, has the power of making its possessor beloved by God and men. Strive, then, each of you, after the worthy life, and he who excels in meekness, in obedience, in rectitude, will prove himself to be the owner of the true ring." Thus is it with him who seeks to know the true Faith.

This broad, comprehensive outlook on the world, this cosmopolitanism of purpose, distinguished Jesus Christ amongs all the sons of men. His disciples even down to our own day have only faintly seen the vision which He saw, and have ever tended both to limit their own love and to place a boundary to the love of God. The Christian teaching, and the 
best thought of all Faiths, is to widen the scope of Love's infinite sway, far beyond the limits of creed or Church, of political mandate or ecclesiastical dictum.

Hence no one Religion is as great as Truth, and Truth is infallible and ineffable only when found in God. In the primal Source there are homogeneity and unity; in the differentiations of divine Truth through the Religions of the world there is heterogeneity, but with it, whilst there may not be unity, there ought to be concord.

Coleridge puts the matter clearly in the following sentence: "He who begins by loving Christianity better than Truth, will proceed by loving his own sect or Church better than Christianity, and end in loving himself better than all."

Dr. Charles Cuthbert Hall says: "The truth is no man's private possession nor is it established by the authority of any man or party. To bring others under its influence is not proselytism."

Whilst theosophy may not be acceptable to all religious thinkers, the following statement of aim amongst members of the Theosophical Society appear to us most excellent: "Their bond of union is not the profession of a common belief, but a common search and aspiration for Truth. They hold that Truth should be sought by study, by reflection, by purity of life, by devotion to high ideals, and they regard Truth as a prize to be striven for, not as a dogma to be imposed by authority. They extend tolerance to all, even to the intolerant, not as a privilege they bestow, but as a duty they perform, and they seek to remove ignorance, not to punish it. They see every Religion as an expression of the Di- 
vine Wisdom, and prefer its study to its condemnation, and its practice to its proselytism."

The final triumph of the Truth; the dominance of goodness and righteousness; men held in bondage to the persuasiveness of Infinite love; God sovereign over all, and the revelations of Himself all completed in finite existence; the Kingdom of God come to earth as it is in heaven; all human desires satisfied and God's purposes fulfilled; every form of Religion, of worship, of doctrine, of method, rounded out in spiritual reconciliation with God; and the grandeur and charm of all the saints and worthies in many lands and throughout the ages, and the supreme leadership of Christ in drawing men unto the Father, with promised hope of eternal life, and blessed forgiveness, and lives made pure,-these are the things we see before our eyes, in the coming brotherhood of th Truth. We close with Whittier:

"Forgive, O Lord, our severing ways, The separate altars that we raise, The varying tongues that speak Thy praise!

"Suffice it now. In time to be Shall one great temple rise to Thee, Thy Church one broad humanity.

"White flowers of love its walls shall climb, Sweet bells of peace shall ring its chime, Its day shall be all holy time.

"The hymns, long sought, shall then be heard, The music of the world's accord, Confessing Christ, the inward Word! "That song shall swell from shore to shore, One faith, one love, one hope restore, The seamless garb that Jesus wore." 


\section{CHAPTER X}

\section{AN APPRECIATIVE ATTITUDE TOWARDS OTHER FAITHS IN ITS BEARINGS ON MISSIONS}

In the appreciations which we have given of other religious Faiths and schools of thought, and especially in the discussion of the last theme on "Unity of the Truth and Concord amongst Religions", it has been made apparent that the usual view concerning missions would most likely be subject to modification. Some no doubt are convinced that the liberal spirit in religion, whatever the nature of the liberality, will certainly cut the nerve of missions, and, whether sound or unsound, it is one of danger to the progress of the Church and to the world's evangelization.

One common remark is this: "If men can be saved without a knowledge of Jesus Christ, why give them the Christian Gospel?"' Still another remark, directed against every form of missionary enterprise, is this: "The need at home is so great, why bother with other people, who are getting along so well with their own civilization and ideas of religion?"

Hence, whilst we do not propose to answer these questions one by one, some reflections are necessary as to the bearings of the spirit of appreciation and liberality on the cause of missions. We wish to 
show what the new concept of missions is, and, further, that benefits and not harm flow therefrom. Indirectly it will also be shown that so-called liberal religion has a part to play in the cause of missions for the redemption of the world.

In giving expresson to views, which arise not only from this series of addresses but from practical experience amongst the Religions of China-views gradually formed through a period of years, and still, perhaps, subject to alteration in the future,we wish to acknowledge our great indebtedness to the different addresses of the late Dr. Charles Cuthbert Hall, President of Union Theological Seminary, New York, and to two articles in "The International Review of Missions" for October, 1912, one by Count Okuma of Japan, and the other, suggestive, sympathetic, well-balanced and illuminating, by Principal Garvie of New College in London.

Principal Garvie along with many other thinkers recognizes the great change which has taken place, both in the theological expression of the Christian Religion, and in a better understanding of the other Religions of the world. Hence he speaks of the "process of readjustment", calling it "perilous" and very near to being "an acute crisis". He also refers, with less fear, to the "solid reconstruction of Christian theology" which is taking place under competent scholars. The liberal spirit, which he has in mind, is not so much that of appreciating the good in other Religions as that which shows itself in the acceptance of science, of the theory of evolution, or of Darwinism; and, through another class of thinkers, in the "higher criticism" of the Bible. The 
main results of these forms of research are evidently accepted by Principal Garvie, but with due caution. In reference to higher criticism he says: "Questions of date and authorship, literary character, and even historical value, are now seen to be matters of indifference to Christian faith, so long as the historical reality of a progressive revelation culminating in the incarnation of the Son of God, and of a final redemption in the crucifixion and resurrection of Christ are recognized."

If the vitality of missions is not weakened by these views of liberal religion, it surely is in no danger from a mere appreciative, and, we may add, complimentary, reference to other Religions.

I.

First of all, then, the new concept of missions places the emphasis on appreciation of the religious beliefs of others, rather than on the destruction or even criticism of these beliefs. The prevalent view held hitherto has been, that other Religions were false and ought to be overthrown.

Should any good be discovered within them, yet, it has been claimed, because of comparative inferiority to the Christian message they were still destined to pass away. The message and the hymns of the missionary have been martial in tone. Hope of victory has spurred him on. All others were doomed to defeat.

There is no doubt that such thoughts fill one with enthusiasm. There is no doubt that similar confidence of coming victory characterizes the hero of 
the battlefield. What is worthy of serious attention is that other Religions, like that of Islam, have also been aroused to service and even to suffering at the prospect of the infidel's downfall.

The newer, and, as it seems to us, the higher, conception of a religious propaganda is that of sympathy and friendliness for those who hold views other than our own, and of appreciation, if not admiration, for the great religious systems, which have won through many centuries the allegiance of millions of our fellowmen.

Mencius has said: "Respect others, and others will respect you." Christ said: "Think not that I came to destroy the law and the prophets. I came not to destroy, but to fulfill." The public ministry of Jesus was not one of antagonism, except to the evil doer, especially the religious hypocrite. He was never "contrary"; he was sympathetic, gentle and kind. Whether He knew anything or not of the philosophical schools of Athens and Rome, He at least, so far as the records tell us, never denounced them. As to Judaism, He did not withdraw from its places and forms of worship, or seek to subvert its fundamental principles. The Apostle Paul, though trained in the schools, likewise made no attack on other Religions. In fact, he seldom referred to them. He, like his Master, only antagonized sin. The one time when he came into contact with religious philosophers, that at Athens, he was appreciative and complimentary in spirit and in address.

It is clear that such a purpose to appreciate others and think well of their beliefs and practices is more akin to spirituality of life and to a Gospel of love 
than is the opposite purpose. When one really determines to seek for all the good that other races and Faiths possess, and to recognize and praise it, a feeling of exhilaration and great joy comes into one's soul.

The conciliatory method, in matters of religious opinion, is one of least resistance. Principal Garvie says: "Possibly the reason why some of the brethren are attracted by this liberal Christianity is that it seems to offer the line of least resistance in dealing with other Faiths." Whether one yields to liberal Christianity or not, he may well feel attracted to the conciliatory spirit in Christianity. He continues: "Sympathy and appreciation of the religious thought and life with which they have been brought into close contact make the exclusiveness of the evangelical type of theology appear intolerance." Referring to the reports sent in by missionaries to the Edinburgh Missionary Conference, he says that "with few exceptions the attitude of the missionaries was appreciative and sympathetic," and he adds :

"That is only what one had a right to expect. The recipients of the grace of God must need be gracious ; they who have obtained mercy should be merciful." In another place, this writer indicates his approval of the appreciative attitude in these words : "A fuller recognition of what is true and good in the beliefs, rites, and customs of other religions, and a better readiness in every missionary to admit what is temporary and local in our presentation of the gospel, seem to be necessary conditions of further progress." 
'Towards the close of his article, he utters a warning concerning too great a spirit of accomodation, but not of too great conciliation. He says: "Adaptation within limits there must be, but let the missionary beware lest he be too accommodating, and so once more bury rather than embody the Gospel in temporary and local forms."

On this point only one word more: The appreciative spirit is for Buddhist and Moslem as well as Christian, for Roman Catholic as well as Protestant, for liberal Christian as well as orthodox evangelical, for unbeliever as well as believer. If one side in any great religious difference or dispute begins and continues in the spirit of appreciation and kindly regard, a response from the other side is almost a certainty. When appreciation becomes reciprocal, the relations between nations and creeds will not be far from perfection.

II.

A second feature of the new concept of missions, rooted deep in the feeling of appreciation of other Religions, is that of comprehension rather than of exclusiveness. In a word, the mistake is now acknowledged that the exclusive spirit, even more in religion than in social life, arouses no response but that of resentment. With such a spirit the Christian missionary will never attract any disciples. Christ was not such. He embraced the world. He was the highest type of a cosmopolitan. He placed no restrictions on God's love, on religious truth, or on man's capacity to goodness and everlasting life. Not one word proceeded from His mouth which im- 
plied that His teachings, since called Christianity, alone made known the infinite mind of God or exhibited divine grace. This truth we have dwelt upon in previous lectures, but here we wish to point out how much greater is the stimulus to missionary enterprise, if one is assured that the people to whom he comes with the story of the Gospel have great truths and many excellences, and that these are all or part of God's kingdom, that they proceed from Him and are His gift to men. The missionary thus comes not only to teach, but ever to learn more and more. He passes out from the narrow environment and circumscribed conceptions of his own town and country to the larger schooling of the world's great Religions. The missionary of all men should have broad views. In fact, more missionaries are broadened than narrowed by contact with other peoples, other races, and other Faiths.

Let me here quote from Principal Garvie: "It is now agreed that religion is universal in mankind and necessary to mankind." And here he is not speaking of a particular system of Religion, but of the common religious substratum of mankind. "What is being established by anthropology and the comparative study of the historical religions is that there is a uniformity in the religious development of mankind. This uniformity is not rigid, as there are climatic differences, racial characteristics, historical conditions, personal influences, which inevitably introduce variety." The writer even goes further in his thought. He adds: "When we take so worldwide and age-long a survey of Religion, it is impossible for us to dismiss scornfully or even angrily, as 
absurd or perverse, beliefs, rites, and customs, which at first contact with them may appear to us irrational and even immoral."

Under this head, we close with these words of Count Okuma: "Let Christians make an effort to find points of contact with Buddhism and Shinto; to cast aside the non-essentials and to emphasize the points of agreement. The watchword of true religionists should be tolerance and inclusiveness."

\section{III.}

In the third place, under the new concept of missions, one is filled with hope as to mankind, rather than with gloom and melancholy, and with a joyful sense of God's infinite love rather than with the susspicion, hardly expressed but none the less felt, that God is arbitrary and partial.

Principal Garvie, after referring to the old view that "all men were perishing without Christ," and that "Christianity alone was true, and all other Religions false," adds: "To us today it may seem impossible to hold the same belief. The revelation of God's fatherhood in Christ, as our mind apprehends it and our heart responds to it, makes it incredible that God should condemn men for not believing in a Saviour of whom they had never heard; and that $\mathrm{He}$ should have left Himself so utterly without any witness amongst the greater part of mankind."

In this connexion we again refer to the modern, and at the same time very ancient, belief in God's immanence, or, from the Christian standpoint, in the universal activities of the Holy Spirit of God. 
Thus writes Dr. Charles Cuthbert Hall: "The critical study of the sources of Oriental Religion, the wider acquaintance with holy aspirations and experiences occurring beyond the zone of Christian influence, have not only added to our knowledge of man but deepened our knowledge of God. That the activity of His Spirit is more mysteriously diffused than an earlier age supposed; that the relations of human souls with God transcend the limits set by theological opinion; that the plan of God for the religious development of the world stretches out beyond our narrow Churchmanship, as the immensity of the sea stretches out beyond the moles and jetties of our harbour-ways-these are amongst the momentous implications attaching to the immanence of God in the light of the scientific study of religion."

This broader and more ennobling outlook on life and conception of the Infinite One will not only meet a glad response in the adherents of other Faiths, but will help them to a better life and higher ideals.

IV.

As a fourth feature of this broader concept of missions, such as is derived from a study of all Religions, supremacy is given to the Supreme Being alone, rather than to any particular Religion or any sacred Scriptures, or to any human being, however exalted. God alone is "all and in all." "To Him be all the glory."

Such a lofty message, the message of the grandest truth that the world has to proclaim or to hear, will antagonize no Religion, not even those which coun- 
tenance idolatry. It is a universal truth, a fundamental doctrine, a living dogma.

What is aimed at is the realization of a correct proportion between God, the Source of all that is, and the Religions, the Bibles, and the human persons, in whom God has dwelt and through whom He speaks to all humanity. No disrespect is cast on any Religion, on any of its Sacred Books, or any of its holy Teachers; rather they are revered, and all the more so, that they are glorified by the glory of divinity. The thought insisted upon is merely this, that God is supreme over all.

Let me endeavour to make clear my meaning by a more specific comparison of that which is first, and that second.

If I should make the statement that it is not the missionary's chief duty to make people Christians, there would be a stir in the camp; but in a sense this statement is correct. Most of the people of Europe are Christians, but this is no great honour to God's working in the world. To be in the Church, to be baptized, to be confirmed, or even to be consecrated as a priest or clergyman, may mean much or mean little. So in China, to lay stress on "entering the religion," as it is expressed, is to lay stress on the wrong place. The supreme duty, the all-important truth, taught indeed in Christianity, and also more or less clearly in other Religions, is that to obey God is the corner-stone of all religion. "Fear God and keep His commandments, for this is the whole duty of man." The Westminster Shorter Catechism puts it thus: "What is the chief end of man?" "Man's 
chief end is to glorify God and to enjoy Him forever."

No Religion, then, Christianity or any other, should supersede God.

We may magnify the Church, and feel stirred by the thought of its continuity through the centuries, as we have seen to be the attraction of the Church of Rome, but we are in error if we idolize the Church more than we adore God, without whose presence the Church would be as nothing.

Equally erroneous is what Principal Garvie speaks of as "a humanitarian and naturalistic Christianity." The new view of missions, just as the broader conception of the world's Religions, recognizes with gratitude the presence of God both in Christianity and in every other religious Faith.

In the same way the Christian may rightly magnify the Bible, but if he makes a fetich of the Bible, and requires the same loyalty to a Book as he requires for the God of the Book, he is by so much derogating from God's supremacy. The Christian theory of verbal inspiration, where every book of the Bible is a revelation from God, and all parts are the truth of God, is the same as the claim made by a class of Moslems concerning the Koran. The broader idea is that the Jewish and Christian Scriptures, like the Koran and other sacred Books, contain the truth of God, and in some cases a special revelation, but that the chief duty is to know and follow the Word of God and the Will of God, wherever and however they are made known to the mind of man. If the Christian has respect for the classics of other Religions, he may hope that others will have respect 
for the great series of classics contained within our Bible.

Equally vital, but more difficult of explanation, is the other thought that no human person should supersede God. The Christian will agree with me that Confucius or Muhammad or Zoroaster should not be elevated to the place of God, and in this assertion I am sure of the assent of the Confucianist, the Moslem or the Parsee.

When we come to speak of the person of Jesus Christ, there is danger of one being misunderstood, but still I venture to testify to the universal and fundamental truth we have advanced by saying that we should not look upon Jesus Christ as we look upon God, still less that he should supersede God. There are those who in their thoughts and their prayers think of God as God, and Jesus as God, and in so thinking think of two distinct persons; in other words, of two Gods. Others try to think of God as One and as Infinite and as omnipresent, and of Jesus as a human person, with limitations, but with God dwelling within him, in other words, as Immanuel. Such an one, when he prays, prays to God, but not to Jesus Christ. God, indeed, as the infinite one "inhabiting eternity," is ever manifesting Himself, and in a special way manifested Himself "in the flesh," "in the name Christ Jesus," but no one manifestation is the whole of the Infinite and cannot be.

And here I give an exhortation to the liberal Christian as to the orthodox Christian. We have in a previous discussion shown how it is that, whilst we believe in the Triune God, though not in the current expression of that idea, we can yet appreciate the 
teachings of the Unitarian. It is equally incumbent on the Unitarian to try to understand and appreciate the underlying principles of orthodox Christian theology, just as he aims at understanding and appreciating the teachings of other Religions.

Principal Garvie has put the matter thus: "If we believe only in religious ideas which are to be commended as truer than others, or moral ideas which are to be urged as better than others, we must be prepared for a very slow progress of the Gospel in the world. If even in Christ we are going to offer to mankind only a wiser teacher and a holier example than Gautama, Confucius, or Muhammad, the advance of Christianty is likely to test our endurance to the uttermost. Only if we confess in the historical Jesus and the living Christ the manifestation and communication of the God who is in all, and through all, and over all, to all mankind, to meet fully the spirit's hunger and thirst after God, to deliver surely the soul enslaved to sin, can we have the certainty and confidence which will inspire constancy and courage that the world will be won for Christ; and as speedily as we have the faith to claim the moral and spiritual resources of God which are put at our disposal in this work of God. The question is not whether we retain this or that theological conception of the past, but whether we have faith, as Christ had, in the Father-God as mighty as $\mathrm{He}$ is merciful, faith in Christ as able to save to the uttermost all who come to God by Him, faith in the presence and power of the Spirit of God to convince and convert all men."

The thought here which seems to be all-important 
is where he asserts that in Jesus Christ there is "the manifestation and communication of the God who is in all, and through all, and over all." With such a presentation of a vital truth, we recognize it is God in Christ and in all, whom we are to worship and to serve, and that God is not exclusively in Christ, but in all hearts, and particularly in the hearts of His chosen ones amongst all nations and in all times.

Professor William Adams Brown in a review of the theological teachings of Professor William Newton Clarke-two liberal interpreters of Christianity within the bounds of orthodox Churches-says :

"To the older Protestantism, as is well known, the trinity had to do with inner distinctions in the nature of God himself, distinctions rendered necessary in order to overcome the fundamental ethical dualism to which we have already referred. These ontological distinctions have lost their meaning for our author. The trinity is a truth of the Christian experience. The distinctions with which it deals concern man rather than God. They express different aspects in which God manifests himself to us as we contemplate the different phases of his redemptive activity. He manifests himself in the order of natural processes which are the necessary presuppositions of the religious experience. He manifests himself in historical revelation and supremely in the person of Jesus Christ, our Lord. He manifests himself, finally, in that personal experience through which we apprehend Jesus as the revelation of the God of all the world. In all three aspects, it is the same gracious God who is revealed." 
In another article Professor Brown states this wider view in a way that no one need fear a lack of zeal for him who accepts it. Speaking of the Bible, he says: "We see that it can no longer be isolated from other books, as was the habit in the old theology." He then continues: "Salvation is not an act wrought once for all in some transcendent realm. It is a process going through the ages, and rooted as truly as sin itself in the nature of man. Calvary is a principle as well as an event. . . . Justification and sanctification are experiences found outside of Christianity . . . . Jesus is not God and man, he is God in man, the first-born amongst many brethren, but the type to which all mankind is ultimately destined to conform:"

The late Rev. Howard Crosby, a prominent Presbyterian of New York, used these words:

"No action of our Saviour's earthly life, from Bethlehem to Calvary, exhibits divinity. He appears first as a helpless babe in the manger. $\mathrm{He}$ is subject to His parents. As the child grows, He waxes strong in spirit and increases in wisdom. Such an increase in wisdom implies increase in knowledge, and less knowledge or greater ignorance today than tomorrow. Omniscience could not have been exercised by the Jesus who was growing in wisdom. If any say here, as we usually do, that the humanity grew but the divinity was omniscient, let us ask if there were two persons in Jesus. This Nestorianism is practically the creed of the present day with the Reformed Churches. They have gone over to a virtual duplication of the person of Christ."

To this statement I am inclined to offer a modifica- 
tion. Christ, as many spiritually-minded Unitarians are glad to recognize, showed forth divinity far surpassing all others of the sons of men, but let us not claim that God has not made use of other prophets to reveal Himself or that into the heart of any man God Himself forbids an entrance, but leaves man to his own vain efforts to rise to the divine.

In brief, the thought of liberal Christianity, to which liberal thinkers in every Religion will give assent,-a thought of wonderfully impelling power to go forth amongst men both as teacher and learner-is that God dwells in every Religion, every Sacred Scripture, and every Holy Teacher, and that the Christian missionary's inspiring task is to co-operate with others in making known "the riches of God's grace" in Jesus Christ, in the Gospel story, and in all the Bible, which tells so fully of God's doings amongst God's children.

\section{V.}

A fifth feature of the new concept of Christianity, which may well be a stimulus to the cause of missions, is the supremacy of a religious leader over a religious creed. We have already pointed out the importance of placing the Supreme Being above every human person, every Religion, and every sacred Scripture. Holding fast to this proportion of values, we now lay stress on another proportion, that which exists between a human person and a creed.

The vitalizing power of Christianity or any other 
Religion is no doubt often traced to what we call truths, or principles, or dogmas, or sometimes a creed; but if we examine carefully the sources of spiritual power, we must see that next to the power of the Holy Spirit of God, able to apply all truth to the human soul, and to guide the soul into all truth, is the power of great religious personalities.

Professor Lucius H. Smith, outlining the teaching of the German theologian, Troeltsch, says: "The centre of a great religion is always a person, its founder; and the essential element in any organization of this kind is the attitude toward this founder. All else is secondary. The cult, dogmas, and creeds are only expressions of this relation." In fact, in all Religions the tendency has been not so much to minimize their illustrious founders and teachers as to exalt them to the point of perfection. This deification has superseded the original historic person.

If we study Christianity, we see beyond all dispute the vitalizing power of the personality of Jesus Christ. In Judaism and Islam, a number of these personalities stand forth, each occupying a definite place as messenger of God. In the other Religions the example and life of a personal leader do not always appear with the same importance, or exercise the same authority. Confucius in Confucianism is indeed highly exalted, in fact too much so, but the veneration created is probably more for a certain idea than for an historic person as made known in historic words and deeds and, more than all, in an historic example. It seems as if most Confucianists like many Christians are influenced more by great principles of the past than by thought of a person. 
This is still more true of Taoism, where the knowledge of Lao Tsze as an historical person is most indefinite. In Buddhism the power is not so much from Gautama as the Buddha, whilst in Northern Buddhism the new Buddha is not a representation of any particular person. Yet even in Taoism and Buddhism, it must be acknowledged that their best form is that of their first leaders.

Personality in every Religion is stronger than a principle. A life more than a creed shapes human conduct. Any Religion must always need the man of vision, inspired of God, to mediate the truths of religion to the souls of others. The crux of all religion is the religious life and not any particular formulary of religion.

The great men of history have been those who thought much on the profound things and spiritual factors of human existence. Such are the leaders of men. We do well to revere them, and we do better if we follow them. In our reverence for them and in fairness to them, let us not tarnish their names by imputing to them faults of our own lives or by finding an excuse for subsequent evils in the fact that we today are followers of these first teachers. Principal Garvie rightly says: "Just as we should resent Christ's being judged by the sins which are found in Christendom, so we must avoid condemning Confucius for all the evils found in China, or charging Muhammad with all the defects of Islam."

Comparatively speaking, then, a creed is inferior to a person. All the Christian Creeds are less than Jesus Christ, and should not in one's affection and veneration, be ever allowed to supplant Him. This 
is far from saying that they are useless; only that Jesus is more than them all. The simple command, adapted to all kinds of mental equipment, is not, "Believe a Creed", but, "Follow Jesus; be his disciple; live as He lived; have the mind which was in Him". Dr. Charles Cuthbert Hall, speaking of the successive theological re-interpretations of Christianity, says: "As presentments of Christian thought, and interpretations of revealed truth, they have been honoured of God and serviceable to man. But their noblest quality has been, not their relative adequacy, but their absolute inadequacy.

In a similar way, Professor Youtz of Auburn Theological Seminary, has written with special reference to the missionary cause: "If Jesus Christ and his message of God's love is to dominate and save Eastern civilizations with their millions of needy people, they must be allowed to reinterpret our blessed Gospel in forms of life and thought which our orthodoxies do not know, and we must recognize the heterodox ways in which God is already manifesting Himself in the hearts of these people. We imperil a world message by parochial thinking. 'There are diversities of operations, but it is the same God which worketh all in all'. Does this not mean that God who works in Islam and in Buddhism is the Father of our Lord Jesus Christ?"

This supremacy of personality is stated by Count Okuma in the following manner: "It is unreasonable to expect highly educated modern Orientals to accept the whole body of Christian teaching even in the Gospels. The controversy whether Christ was God or man is to me irrelevant. What I want is to 
know about His central teaching; to come into contact with $\mathrm{His}$ superlative character; and to understand His strange power to draw and inspire men."

From Principal Garvie we make several citations : "The Western Confession or the Thirty-nine Articles, or even the Nicene or the Athanasian Creed do not assuredly give us the form in which Christianity is to be taught throughout the world. . . . The œcumenical creeds did not unite, but divided Christendom. . . . The world-wide conquest of the Gospel must be retarded by division, and can be hastened only by unity, a unity of common faith, hope, love, rather than a uniformity of creed, code, or polity. . . Modern theology is seeking to free the doctrine of the Person of Christ from the Greek metaphysics, to which in the creeds it is adapted."

What we desire to emphasize as to Christianity is that Jesus Christ is more than a creed or any human interpretation of Christian truth. After the personality of Jesus there grew up "the cult of Christ, in which Jesus of Nazareth was worshipped, not as God, for this was not the original idea, but as Messiah and revealer of God, the complete revelation of Jahve, the fulfilment of the prophets, the revelation of the Father". This distinction between a person and a cult or creed is more significant in Christianity than in other Religions, but it is a distinction that the adherents of other Faiths, with their own veneration for the Founders of these Faiths, are quick to recognize and appreciate. The story of the life which Jesus lived, whether thought of as Son of Man or Son of God, and whether the life be the divine life of a man or the human life of 
God, or, free from all intellectual inquiries, be taken simply as the life of a person called Jesus, who lived in Judea and Galilee some 1000 years ago, is a story far more effective in shaping character than the mere intellectual effort to grasp and give assent to a creed. Stating the orthodox position in simplest language, Principal Garvie sums up, "the original and essential Christianity" as "faith in God as Father, through Christ as the Saviour, in the Spirit as renewer of man."

This much is clear that every Christian, who is devoted to this supreme personality of all history in the realm of spirituality, should rejoice to tell the story of his life to all in every land who have not heard his name or have not seen aright the excellence of his character, the attraction of his spirit, and the power of his teachings.

\section{VI.}

In the sixth place, carrying out the idea of a proper proportion, truth is placed ahead of Religion. The new form of Christian missions means, then, zeal for the propagation of the truth, rather than zeal for the propagation of Christianity as a system of Religion, or propagation of the Church or any sect.

A saying of Marcus Aurelius is this: "I search after truth, by which man never yet was harmed." Not only Jesus Christ as a person, but truth also stands ahead of creed and church. We quote again from Coleridge, who said: "He who begins by loving Christianity better than Truth will proceed by 
loving his own sect or Church better than Christianity, and end in loving himself better than all." Dr. Charles Cuthbert Hall says: "There is an increasing number, in and out of Christian pulpits, who believe that the first interest must be truth; to hold things and to preach things not because they are declared true, but because they are true." And again he says: "Increasing sense of brotherhood in the truth is one of the notes of the present time. It is that which takes the place of the sectarian spirit. The truth is to be followed as a leader, whithersoever it goeth. It is not bound by man's attempts to define it and to enforce those definitions as absolute."

There may be those who have lost their confidence in the Churches, in the clergy, in Christians, but if they hold on with a firm grip to the general idea of Truth, and to domination of all truths in so far as they are seen to be truths, then not yet have they broken loose from the great brotherhood of truth, nor do they deserve to be ostracized of Christians. The Rev. Charles F. Dole has expressed it thus: "Call this, if you like, an age of question and doubt. It is also an age of faith,- - faith in truth, faith in progress, faith in God and a universe, growing faith in the humanity of every race and colour."

Devotion to Truth, the desire to know more of truth as revealed throughout the world and the kindred desire to impart to others all the truths which one has received, should impel every Christian, however liberal his theology, to enter on the large and universal Mission to propagate the truth, or, perhaps better stated, to intercommunicate the truth. 
If we once get behind all dogmatic statements, and have a realization of the inner soul of dogma, Church, and Book, we shall find disclosed many an inspiring truth which men will be glad to know.

I have found that the followers of other Religions often resent our magnifying of the Christian Religion as superior to theirs, but they never resent an appeal to follow the truth. Greater is their response, if they see that the truths contained in their Religion are not denied or condemned by the teacher of Christian truth. To follow a Religion is to follow something specific; to follow the truth is to follow that which is universal, unifying, and permanent. A Religion or a creed is only one way to exhibit the essence of truth as abiding in God. "No dogma is, or has been, or ever will be, the absolute truth, for the absolute lies ever beyond the confines of human history."

The old method of prosecuting missions is either to represent Christianity as the only true Religion, or, through a comparison, to represent its superiority. Such an attitude antagonizes and creates jealousy. It intensifies rather than weakens opposition.

The new method lays stress on truth, and whilst certain truths may be regarded as more vital or fundamental than others, there is not the same rigid line of demarcation, creating a mutual antagonism. We have shown that unity characterizes Truth, but the divisive spirit characterizes the relations between the great competing Religions.

Principal Garvie, whilst unusually sympathetic to the thought and intent of others, has not escaped from the old attitude to the new spirit of what may 
be called religious fraternity and equality. At the begining of his article, "The Christian Challenge to the other Faiths", he uses the following language: "On the one hand it must be shown that Christianity is the absolute religion, meeting adequately and finally the necessities and the aspirations of the soul of man; and that therefore its missionary intention is warranted by its universal value for mankind. On the other hand, it needs to be proved that whatever truth and worth there may be in the other religions, yet even at their best they do not fully meet the religious needs to which they bear witness, and are still less capable of evoking and completing that higher development of man as a moral and spiritual personality which is found only where the influence of the Christian Gospel has been felt." Towards the end he also says: "It is easy to indulge in generalities; but we should like to be told what religious idea or moral ideal these Religions can contribute which. Christianity lacks." Quite likely it will be acknowledged that this sense of superiority in one's own Religion should not, for the sake of prudence, be made too prominent, lest it be taken as a species of self-assertion. Still the idea, if it is in the heart, will sooner or later come to the surface.

The appreciative attitude is content with the proclamation of truth, of whatever form, and whatever the race or the mind which gives it birth, knowing that Truth has a power all its own. It is not a question of, "Mine is better than thine", but rather, "Let us all learn together from God as to the truths $\mathrm{He}$ has imparted to each or to all of us".

Principal Garvie, speaking of liberal Christianity, 
says: "I do not believe that the impoverished gospel which the radical criticism leaves us is adequate for any length of time, amidst the strain and stress of the foreign field, so much more severe than at home, to sustain the vitality of the faith or the vigour of the service of the missionary." Granting that his is true of "radical criticism", it is not true of Christians with a liberal view of Christianity, appreciative of all that is good and true in every religious Faith. He who unreservedly submits to the guidance of truth, and believes its unity of essence and universality of adaptation and divinity of origin, is rich and not impoverished in the message and mission he brings to the men of other lands and other Faiths. He comes as an equal and brother in the realm of truth.

\section{V1I.}

In the seventh place, the new concept of religion is to lay deep the foundation in universal essentials and not attempt to build on things distinctive and unessential. The first truths are universal truths, truths that are self-evidencing. To give them the prominence they deserve is what the followers of other Faiths can best be stirred by, and to which they naturally respond. Because men already know a certain truth is no reason for our refraining from proclaiming it. What is probably needed is its revival in one's consciousness by being re-invigorated from the insight and conviction of Christian experience. Even with Christians many a truth needs new emphasis. It is easy to get spiritually 
blind. Prophets are needed to flash in more light, and the physician of the soul is needed to bring back the eye-sight.

I quote from Count Okuma: "It is an inspiring thought that the true religious ideals and experience of all races and peoples are bound to persist and to form in time one noble and comprehensive whole. The true and good will persist, and the non-essential and false and ephemeral will be left behind. The races are at bottom one, and truth is one."

So Principal Garvie says: "It is not the interest of Christian faith to represent the Christian Religion as 'a bolt from the blue'."

In laying chief stress on essentials, the stress is laid on that which is universal, inherent in the teachings and aspirations of all Religions. This does not mean that every individual will have these common religious ideas and beliefs, but that people in general, as typified in the great Religions, have certain ideas in common.

By laying stress on non-essentials, that is, on distinctive features of each Religion, it is not meant that these are of no importance. They are merely given a position subsidiary to the essentials. Dr. Charles Cuthbert Hall says: "Great Religions, like great men, have strongly marked distinctions, whereby each is set apart from others."

In certain respects the distinctive features of a Religion are its most attractive features. The tendency is for the advocate of a particular Religion to emphasize that which is peculiar to his Religion, and does not appear so distinctly in other Religions. That which is exclusive is regarded as the most 
precious. It forms the reason for adopting a Religion, seeing that nowhere else can the same precious possession be found.

The Christian missionary has heretofore followed this natural impulse. He claims superiority for Christianity because it has so many truths or doctrines which other Religions do not have. The new method is to place ever to the front the essentials and universals, and, even where specific and distinctive truths or doctrines are to be taught, to trace them back, as far as possible, to these essentials and universals.

The late Dean of the Harvard Divinity School, Dr. Charles C. Everett, in his book on "Theism and the Christian Faith", speaking of the content of the Christian faith, says: "That content is both general and special. Of the doctrines that are specifically Christian we find that in the history of the Church there have been regarded as fundamental, the doctrine of the Incarnation, the doctrine of the Atonement, and the doctrine of the Trinity. Of these the doctrine of the Incarnation is the most fundamental." In another place, though himself a liberal religious thinker, he states forcibly the reason for bringing to the front these specific Christian doctrines: "The shrinking from emphasis, from the recognition of the real perspective in things, is one of the failings of our time. If in studying the various forms of religious feeling, we shall only make a mush of the whole examination; we shall have lost the delicacy and accuracy which belong to any true historical study. For Religions do differ amongst themselves, they differ in the emphasis that is placed 
upon the various aspects of the religious life." We, too, claim a real perspective in things and differences of emphasis; only we place chief emphasis on the essentials and universals. Even Dr. Everett makes clear that Christianity must satisfy "the three ideas of the reason, unity, goodness and beauty".

According to the appreciative attitude to other Religions, the three specific doctrines of Christianity, or any other, are a moving force in man's thinking, in so far as the inner principle of these doctrines,-the life of an organism-is harmonized with the life-giving principles of universal man or of all the great Religions. It has been made clear that amongst the universal beliefs of men, there is belief in one Supreme Being, in His presence everywhere, and in His love and mercy. This belief is strengthened and intensified by the way God has manifested His purposes, love, and spirit in the man Christ Jesus. But, this is the germ thought of the Incarnation.

Again, all Religions teach the supreme duty of submission and obedience to God's will. This obligation is strengthened and intensified by the way Jesus succeeded in doing the will of God, and in the hour of trial and suffering, in submitting to that will. But this, too, is the germ thought, from the human side, of the doctrine of Incarnation.

Historical facts are also to be believed. The facts of the birth, the crucifixion, and the resurrection of Jesus seem well established. These are amplified into the doctrines of the Incarnation, the Atonement and Immortality, or, rather the Resurrection 
of all men. I have found that audiences of nonChristians respond to these doctrines, if thus rooted in historic facts.

All denominations of Christians are useful in that they each bring out into the light some special form or phase of Christian truth. So all the great Religions have had their use, because they each bring out into the light some special form or phase of universal religious truth. The Christian, liberal or orthodox, may well be stirred by the manifold ways the underlying religious sentiments of hope and faith and love are given new vigour and meaning in the story of God's working in the world, as told in the Old and New Testaments, and whose climax is seen in Jesus Christ. What we wish to make clear is the importance of taking Christian truth as the unfolding of already-existing truth inherent in our common humanity. On this head we close with words from Principal Caird: "The new element which Christianity has introduced into the thought of the world transforms, elevates, works a fundamental change in all the previous materials of religious knowledge. It takes up these materials into itself, but it takes them up as the plant takes up air and earth, and moisture and light, or as the living body takes up the matter which constitutes its food-not transferring them wholesale, but by its inward organic chemistry, subduing, disintegrating, reconstructing all that it receives into similitude with its own nature." 


\section{VIII.}

In the eighth place, according to an appreciative attitude toward other Religions, the first thought will be to do good and to save rather than to make converts or to proselyte. The time once was when Christian sects sought to make converts from each other as to a truer Faith. Now there is less worry as to the fate of those who believe differently from ourselves, and less zeal to magnify our sect over those of others. There are some, like Bishop Brent, who object to missions amongst Roman Catholics, if the purpose is to induce Catholics to give up their own Church. Viscount Bryce has also commended the educational method of American missionaries in Syria and Turkey amongst Moslems as better than direct effort at wining converts.

As a rule, however, all missionary Societies regard evangelization as synonymous with proselyting, or, if this word is disliked for being too brusque, with making Christians. It is, in fact, much easier, as has already been pointed out, to arouse zeal for one's own Church or for the Christian Religion than for such general ideas as accepting truth, doing good, helping men, and saving others. The new concept, whilst conscious of this fact, places the work of making converts from one Religion to another below the duty which is more universal and positive. Dr. Charles Cuthbert Hall says: "The sectarian spirit is either aggressive or segregative, In its aggressive form, it assails the theological position of others and seeks to make converts to its own. It compasses sea and land to make one proselyte. 
In its segregative form, the sectarian spirit ensconces itself within the stronghold of orthodoxy, zealous to maintain an unimpaired body of doctrine; its interest is with its own affairs; it is indifferent to the problems of criticism, or looks out upon them with disfavour as evidences of popular unrest which rashly re-opens questions closed by authority. The spirit, once generally held to be a normal expression of religious earnestness, has now given place in many quarters to one in every respect its opposite. The sense of brotherhood in the truth is a state of mind neither aggressive for proselytism nor segregative for self-protection. It is full of activity and effort, but there is nothing in its activity analogous to the zeal of the sectary to bring others into line with his opinions. The activity is wholly on behalf of truth; it represents the spirit of Isaiah's phrase, 'valiant for the truth upon earth'. It considers the truth to be that which is good and worthy and necessary; the only thing that can satisfy man and save the world."

Principal Garvie, whilst unusually sympathetic and fair-minded, closes his article with apparently a defence of the exclusive character of Christianity. We quote his words: "We shall not discover the Gospel by comparing ideas and ideals, although even here Christianity need not fear the comparison; but only by comparing the power of cleansing, enlightening, and renewing the soul which resides in Christ as Saviour and Lord with the influence of any other teacher or master. Can Confucius, Gautama, or Muhammad do what Christ has done, and is doing, to save and bless man? Is the kingdom of God a 
supernatural reality present and potent in human history?" It is indeed true that the kingdom of God, viewed as something larger than any ecclesiastical delimitation, is "a supernatural reality present and potent in human history." If we would modify Principal Garvie's excellent statement, it would be in tracing "the power of cleansing, enlightening and renewing the soul" to the spiritual presence of God in the human soul, and to that greatest of all channels for God's grace to flow through, the personality of Jesus Christ.

The positive method of bringing God's grace and truth into the world of humanity was the method of Jesus. He was not keen on making converts as were the Pharisees. He went about amongst men "doing good." He healed men's diseases, not on the condition that they accept a new Religion, or even become his disciples, but because he possessed the power and was under obligation to use it. "When he saw the multitudes, he had compassion upon them", and his compassion was not limited by the question whether others had any compassion or not, or even responded to his compassion. He helped men in every variety of form, and the spirit of helpfulness was rooted and grounded in love. His one desire was to save the world, not the Israelites only or the people of his generation. But what is salvation, as explained by another term? It is the work of helping others. Jesus' aim was to save men from everything contrary to the perfect will of God, whether the escape from sin, from suffering, from disease, from ignorance, from doubt, from despair, from wrong social customs, from unjust economic condi- 
tions, or from anything unsuited to the kingdom of God. Reconciliation with God, harmony with God, is the positive and higher form of salvation. Helping others may be called the lower and human side of salvation. But, whatever the term used, Jesus did all he could for the good of others, asking no questions as to their willingness or refusal to enter the Church which he proposed to establish. He committed this high task to his followers.

What, then, is the thought of the Christian missionary, if he holds to the broader view of religion? He will say to himself and to others: "God has committed to me certain power, and whatever the power be, I am bound to use it for the good of others. I know truths unknown to others, and I perceive the truth in a new light; I will tell others what God has revealed to me. I will limit my efforts to no one race or nation. I will try to be as cosmopolitan as Jesus was. Providence permitting, I will give of these blessings to the people of China, or Japan, or India, or other lands. I will give without stint what God has given to me."

I can imagine nothing more inspiring to a Christian or a Christian missionary than ideas like these. There is a positive message, a purpose of helpfulness, a desire to save, a Gospel which is through-andthrough "glad tidings", a constructive and not destructive policy, and a sense of priority in the performance of one's own duty. The thought of gaining adherents, increasing the Church roll, filling out statistics, or destroying by open or hidden methods the power of other Faiths, is left in the background. 
Here, again, there is a true perspective of values in truth, and of duties in life.

"Freely ye have received, freely give," this is the mandate to the Christian world. Should the proselyting spirit be still held as more desirable than the positive method of doing good, whatever the response or the result, it may be that a place will yet be allowed within the bounds of Christian missions for a broader view, appreciating other Faiths, and none the less appreciating in an whole-hearted way the simple but sublime truths enunciated by Him of whom it was said, "Never man spake like this man", Jesus the Christ, Lord of the hearts of men, and Saviour of the world.

Only one word more, a word of corroboration. The International Institute was organized as a Society to include men and women, without regard to nationality, race or creed. As no man is urged to change his allegiance and be naturalized in some other country, so no man is urged to change his Religion. We have week by week our meetings of all Religions, conferring together and learning from each other, but we are content with preaching the truth, as each one sees it, or as the Religion which one sees it, or as the Religion which each one accepts has made it known. Our aim is the brotherhood of truth, the concord of Religions, the universal peace of nations.

We now bring to a close this series of addresses which we have been asked to deliver under appointment of the trustees of the Billings Lectureship, and by the courtesy of the American Unitarian Association. We are grateful for the generosity that has 
been extended to us. No restriction has been placed on our expression of opinions. We have been left perfectly free in the choice and general treatment of each subject. We trust that the spirit in which we have approached the religious beliefs and aspirations of a great variety of thinking men in East and West has commended itself to those who thought it well to have such a series given in China. We have finished these lectures, but this does not mean that we have finished our studies, still less that we now bring to an end the spirit of appreciation and sympathy for those who think on religious problems differently from ourselves. We are assured that many of our fellow-Christians in China and abroad have seen the value and reasonableness of this method of approach, and we hope that those who belong to other Faiths will likewise in their attitude to Christianity and to Christ feel moved to come into the sunlight and breathe the open air of a large love that knows no bounds and excludes no soul.

"Descend Thou from above, Spirit of truth and love,Speed on Thy flight! Move o'er the waters' face, Spirit of hope and grace, And in earth's darkest place Let there be light!" 
APPENDIX NO. 1.

\section{CHRISTIANITY AND THE GREAT WAR ${ }^{1}$}

Concord between different Religions ought to result in concord between nations. Such concord is at the opposite extremity of war, either religious or international. For a war to exist today shows that something is lacking in the particular religion which is mostly concerned in the war.

The relation of Christianity to wars in general is of less importance just now than a careful study of the relation which Christianity bears to the present great war. This war is unparallelled for its worldwide catastrophe. The war is more than a European war, it is a worldwide war. It began with a dispute between two nations in the south-east of Europe, Serbia and Austria-Hungary. This brought in Russia, and Russia brought in Germany, and Germany brought in France, Belgium and Great Britain, and Great Britain brought the war to all parts of the globe, not only into all British Colonies and Possessions, but into regions where Germany has had an interest, or where her ships have been found sailing on the seas. Every continent and every ocean have been affected. The war spirit, like electricity, has encircled the globe. From the North Sea the war

${ }^{2}$ The lecture is printed as it was given to a Chinese audience, April 11. 1915. It may be that the ideas will yet prove sound. 
has spread its havoc to the extreme southern limits of South America. Africa, north and south, east and west, has heard the call to battle. The Atlantic, Pacific and Indian Oceans have heard the sound of cannon, and islands hid away in the deep waters have passed from one master to another. To the war god Japan has gladly bowed the knee, and through her the war has swept into China and brought about unexpected complications. For all this the great war will appear in a different light to him who views it from China from what it does to him who views it in Europe. The war is seen here to be not merely a European war but an Asiatic war, with just the possibility of becoming more Asiatic than European. Already, by the entrance of Turkey into the war, all Western Asia has been stirred; Persia has been affected; Singapore has had a mutiny; parts of India have grown disaffected; all Siberia has throbbed to the march of troops; and Japan has sent forward her soldiers into strategic centres in China, as if expecting a war once again between these two nations of Eastern Asia.

No such war has ever occurred before; its blight rests on all mankind. Besides being more widespread than is known of any other war, it stands forth as the supreme effort of the human mind to wreak its vengeance on hostile nations. The weapons of death are unsurpassed for ferocity and horror. Governments, like individuals, vie with each other in starving the people of an enemy's country. They seem to gloat over the misfortunes of neutral nations. The angel on the white horse flies through 
the air, dives into the sea, and rushes with electric speed across the continents. The new type of bravery is to face, stolid and indifferent, the frightfulness and barbarity of war, such as heaven and earth have never seen before.

This is the war, then, not some other war long since passed away, which we ought to study in its relation to religion.

The particular religion most closely connected with this war is the Christian Religion. Other religions, like distant peoples, have been brought in at the instigation of Europeans. Moslems, Hindus, Sikhs, Buddhists and idolaters, have been invited to the battle-fields to see how Christians can fight. It is a spectacle over which angels might weep, and the sun once again hide behind the clouds.

By the Christian Religion, in this discussion, we mean Christianity in general, for all branches of the Christian Church are to the front in this tragic scene. The Holy Orthodox Russian Church is there; the Roman Catholics of Austria, Bavaria, Belgium and France, are all there; the Reformed Churches of Prussia, France and Great Britain are also there; even smaller branches of the Eastern Church have been suddenly swept into the whirlpool of these modern horrors and deepset hatreds. Other religions have merely come in at the beck and call of the European Christian. It is inevitable that Christian and non-Christian will stop to ask, "What relation has Christianity to this war?" Nearly every intelligent Chinese is pondering the question, and is sorely puzzled as to the answer. He not only fails to understand why European nations should be so 
keen on killing, but he still less understands how the entrance of war into China and the way China is being treated, should be tolerated by advocates of Christian principles.

Personally I have no sympathy with any kind of war; people should have enough sense and piety to get along without it. Personally I have a firm faith in the teachings, efficiency and world-wide adaptability of Christianity. How this religion and this war seem to be boon companions, when they ought to be foes, I will now venture to express, and I crave indulgence if my views appear unsound.

To make clear the situation, we need to distinguish between certain elements which enter into the situation.

The first thing to distinguish is European civilization and the nations at war from Christianity. There is a fallacy in calling nations Christian nations, and in speaking of European civilization as Christian civilization. Five of the nations now at war have a State Religion, and most of the people of these countries are admitted into the Church in infancy. But how far has the Christian spirit permeated these nations? Christ would find it hard to detect His teachings in these nations today. Christian requirements are subsidiary considerations. As to European civilization, a larger part has come from Christianity, but Roman law, Greek ideas, Teutonic, Slavonic and other characteristics, and many other influences, have all entered in to form what is known as European or Western civilization. To argue for Christianity by citing a civilization, rather than certain elements in the civilizations, may 
sometimes carry weight, and at other times prove a stumbling block.

All the nations which have entered into the war did so without regard to Christianity. National interests rather than the behests of religion compelled them to take action. It was not till war was determined upon that the aid of the Church was sought, with the blessing of priest and pastor, the comforts of the sacrament at the moment of death, and the protection of God in the hour of strife and danger. War broke out in spite of religion; war was the work of diplomats and the outcome of militarists; it did not issue forth from the prayer-meeting or the early mass. National interests, not Christian interests, were of first consideration. When war was made to appear a necessity through the contrivance of diplomats, then it was that Christians were asked to help, and as patriotism is a Christian virtue, Christians did not long delay in rising to the defence of their country. But the fact to be borne in mind is that nations and governments and a particular type of civilization, not Christianity, were responsible for this war.

A second discrimination which is needed is that between the spirit of the age, and the spirit of Christ. The spirit of Christ is love, joy, peace, and righteousness. The spirit of Christ is one of supreme courage, even courage facing an ignominious death, not courage that hastens into battle. The impression on unbelievers and the adherents of other Faiths is that Christ is a supporter of peace, not of war. His patience, forbearance, meekness, gentleness, longsuffering, compassion, love and forgiving 
spirit, seem so incompatible with the war spirit, that many have taught passive resistance as the highest virtue. It often appears that the spirit of Christ is found less in the great State Churches than in smaller religious Societies, like those of the Moravians and the Friends. As to the one question of peace or war, the liberal religious thought of Christendom is generally on the side of peace, whilst the rigidly orthodox too often extenuate, if they do not actually approve, this and other wars of their own time and country.

Very different from this spirit of Christ is the spirit of the age. Judging from the startling experriences of today, the spirit of the age is the spirit of militarism. It dominates not only Germany, but France, Russia, the British Empire, and Japan, and has now sprung into being amongst a large class of thinking Americans. For years the great Powers have groaned under military and naval burdens, and the present war stands as good a chance of perpetuating militarism and armaments as of bringing about the discarding of the arbitrament of war for the reign of Reason.

Between the spirit of the age and the spirit of Christ there is a conflict today, as to which shall win the allegiance of men's minds as well as of their hearts. Sentiment bows to the spirit of Christ, and Christians who follow Christ rather than a Church are viewed by men of the world as meek and sentimental, whilst the spirit of the age develops masculine discipline, sound judgement, economic foresight, and national independence. The world-wide war of today emanates from this masterful spirit of the age 
rather than from the spirit of the Christ. Whatever glory the war has to bring, let it all be given to this dominant note of militarism, to the strong spirit of the modern age, the spirit which rules Europe today. As for Christ, I fancy He wants naught of the glory; rather $\mathrm{He}$ grieves at the sight as $\mathrm{He}$ witnesses its hatreds and horrors from the higher realms of the Kingdom of God.

A third discrimination is that which separates national prosperity imbued with Christian principles from that which follows the teachings of the great Powers of the world.

It is often argued that China should adopt Christianity because the strong and prosperous nations are Christian, and because most of the peoples of the world are now under the rule of Christians. Does the present war shew the desirability of such strength? Would the type of Christianity thus adopted be a Christian type? Some months ago this argument was an apologetic for Christianity, today it is found somewhat annoying.

At the moment, all but one of the six strong Powers of Europe are at war. Strength, power, is the key-note of national prosperity. Japan is prosperous, because she has a strong army and navy, whilst China is not prosperous, because she is weak on the military side. According to these teachers of the West and of Japan, China can never be prosperous and independent till she, too, spends millions on a mammoth army and a huge navy. This is the kind of prosperity which shines forth from the battlefields of Europe-countries impoverished and decimated by war. 
The prosperity which results from Christian principles as well as personal character, is of a far higher type than that which depends on Force, and brings with it contentment, quietness and peace. This is the prosperity which we urge on China, though advocates of the other type are today "in the saddle". Let the Chinese at least recognize clearly that this forceful type, sure to result in war, is not akin to the essential principles of Christianity.

A fourth matter to be discriminated is Christianity organized as the Christian Church and Christianity as a teaching of truth. Zeal for the Church, or for a particular sect, may be so strong as to overlook the inner substance and the living principle. A form may predominate over the essence. Christianity may even be exalted into a State Church, and Christ be forgotten. To put the stress on one Religion as opposed to others will end in rivalries and collision. To put the stress on truth as it comes from God and as Christ lived it, truth entering into all Religions and amongst all peoples, will unify. The large branches of the Christian Church consist not only of the simple original truths taught by Christ and His Apostles, but of traditions of past ages, of the decrees of Church Councils, of creeds and formularies, which are as binding as the laws of the Medes and Persians. The Church is a vast human system enveloping the living spirit of the Kingdom of God.

Bearing in mind this distinction, we can see how it is that whilst this war, as many wars in the past, is out of unison with the underlying truths taught by "the meek and lowly Jesus", yet it finds sympa- 
thetic support from great Church leaders, from Christianity as humanly developed in the life of nations. It is the individual Christian, rather than the great organized Churches, by whom the war is looked upon with abhorrence. Even the freethinker, who is a radical religiously, sounds the note of loyalty to the clear utterances of Jesus of Nazareth, and turns with grief from the fierce contentions of warring nations. The truths of Christ are as clear as the light of day, and their meaning points one way, to "ways of pleasantness and to paths of peace".

As a deduction from this distinction is another important distinction, that between Christian truth and Christ. Not only is the Christian Church unequal to Christian truths, but Christian truths are unequal to Christ. It is possible for the Church to enter enthusiastically into the war, though the principles of Christianity may appear at variance. It is even possible for Christian principles to be accepted, and yet allow them to remain in abeyance under the orders of one's Government and the laws of the State. When, on the other hand, the perfect standard is found in Christ, when His life and spirit are absorbed, and when, true to His words, the resolution is made to do the will of God, then vitality and dynamic power enter into truth and into the acceptance of truth. The critic, who abhors war, and especially the present war, may be dissatisfied with the doings of the Churches, and may be puzzled with the various interpretations of Christian truth, but the example of Jesus the Christ will pass before his vision as the "one altogether lovely", full of charm, 
complete and satisfying. Interpreting that life in a natural sense, we can safely say that war receives from Him no countenance, and that peace in its sublimest form is personified in Him.

Only one passage in the Gospels has sometimes been construed as countenancing war, and that is where Christ said that $\mathrm{He}$ came "not to bring peace but a sword". Interpreting these words by the general trend of His teachings and the evident purpose of His life, we must regard these words as merely indicating that His followers would certainly meet opposition and hostility, and that suffering, even from the sword, rather than peace, awaited His faithful ones. It is contrary to the spirit of Christ's life to suppose that He purposed or desired to bring about war. The duty of enduring sore trials, persecution and the martyr's death, is very different from encouraging war, whether between Religions or nations. Beyond a doubt Christ stands forth as a Prince of Peace not as a man of war.

Thus, should the Christian Church, in any of its branches, or should any of the Church's teachings and dogmas, actually favour war, and particularly the present war, it is due to Christ to recognize His supreme personality as the perfection of love, peace and good will.

There remains a sixth distinction and that is that, though the mass of the people and their rulers in Europe are Christians, and in the main have been opposed to war, yet through the action of Governments the war was unavoidable. It is a fallacy to think that because the people of a country are Christian, and the ruler Christian, every action of the 
government or the ruler will necessarily be Christian. Nations in their international competition must be governed by self-interest, or, speaking more correctly, by the purpose to protect the interests of the whole country and all the people. Thus in the present war the Emperors of Russia, Austria and Germany and the Kings of England and Belgium are Christian men. The Kaiser is even a devoted follower of orthodox Christianity. Personally every one of these men probably prefers peace to war. They would do nothing to cast discredit on the Saviour of the world. But the conditions existing between one nation and another have been such that one after another of these nations and of their rulers has been forced into war, and all under the idea of national self-preservation or out of loyalty to some binding contract. Only gradually can the relations between nations become such that some general principle, as enunciated in international law, will be accepted by all, with no infringement of national rights and interests. A Hague Peace Conference, with its provisions for arbitration, and finally with the establishment of an international judicial Court, will make it possible for Christ to rule rulers, with no danger to national existence. The abandonment of individual selfishness and of national selfishness, all nations progressing alike, without clash of war, is the ultimate out-come of development under Christian influences and is nearer today than ever in the past. The present European war is a stage in the development, and not so far as some think from this goal to which the whole creation moves.

With these six kinds of distinctions, we are better 
able to understand what is the real relation of the Christianity of Christ to the awful war now being waged throughout the world, and in which Christian peoples are taking part with relentless fury.

This war in Europe is the first general one for a century. In the century before, hardly a year passed but armies were marching to and fro throughout the whole of Europe. This war is so ghastly and so calamitous, that men will desire rest not only for a century but perhaps till the end of the world. The forces of peace will get together as never before and have a chance to apply the highest wisdom to the prevention of war.

Men's efforts prove futile. Their best desires get checkmated. Peace amongst the nations might never come, if only man was in the problem. But God reigns, and his breath breathed into human lives will vivify the hopeless cause. We look for the return of Christ, not perhaps as the ascended Nazarene, but as a Spirit of Power and Love, and He will change the course of history.

If China wants to learn, let her learn not the form of Christianity now being displayed in the European war, but the form lived by "the meek and lowly Jesus", whose personal character stands forth blameless. 


\section{APPENDIX NO. 2}

\section{RELIGION AND THE BROTHERHOOD OF NATIONS ${ }^{1}$}

In the series of addresses which we have been giving at the International Institute from Sunday to Sunday by arrangements made with the Billings Lectureship of Unitarian Christians in Boston, we have dwelt on the importance, the worth, and the fascination, of bringing about the spirit of concord and conciliation between one Religion and another or between different schools of religious thought within the same great Religion. Our method has been to express appreciation of others and others' creeds. Whilst fairness united with friendliness, and friendliness united with fairness, are difficult to attain in discussions of religion, the general result of our conferences has been most satisfactory. Mutual good-will amongst persons of religious conviction is by no means an impossibility.

It has generally been supposed that concord and conciliation amongst nations was more within our reach than concord and conciliation amongst Religions. The present great war in Europe-or rather on all the continents of the globe-has knocked on the head many a beautiful theory as to peace on earth or good-will to men, to say nothing of glory

${ }^{1}$ What was said in Shanghai, China, October 3rd, 1915, remain for the most part my thoughts in $1921-G$. R. 
to the God and Father of all. The pendulum of the world's thought has swung far over to the other side from that of international conciliation and universal brotherhood of a few years ago. Even Christians are growing pessimistic; if not actually pessimistic, too many are cultivating the spirit of hate, in their relations to warring foes. Some in their hearts are inclined to believe that Christ's ideal is only an ideal and not practicable for the rest of humanity. The joys of international and religious fellowship have for the moment ceased; the old songs of trust and charity, if sung at all, rise from the lips with the self-consciousness of insincerity. Something more martial suits the times better. We are again singing the Psalms of David, especially those that are beyond a doubt imprecatory. The thirteenth chapter of First Corinthians does not now extend beyond one's nation and its allies. Possibly the neutral comes in on the outskirts of this affection. The enemy is wrong, and we are right, of this there can be no dispute. When wrong exists, we must be just in any case, so it is argued, and if we love at all, we may love afterwards, when the sinner is penitent.

Perhaps it would be well, in these days when the ties between men and nations are being broken, when dark clouds rest on the face of the earth, if the method of appreciation, applied so effectively to the great religions, were also applied to the great nations, to republics, kingdoms and empires. At present we content ourselves with the true significance of nationalism and internationalism, of patriotism and brotherhood, of loyalty to one's own government and devotion to the federation of the world, and then 
we touch on the bearings of a general religious sentiment, no matter the name of the religion, upon these two opposing tendencies in the political and social life of our common humanity.

Patriotism is a virtue which for many centuries has been looked upon by many peoples as the supreme virtue. Internationalism, on the other hand, is an idea which human minds are just beginning to understand, a virtue which is only slightly appreciated and is seldom made supreme. The true relation between these two virtues is not clearly determined, and many fail to see how the one can be cherished without excluding the other.

First, then, the virtue of patriotism, the conception of nationalism. Whilst familiar to us in the West, it has been said there is no word for patriotism in the Chinese language. True there is no one word or character, but there has always been the idea, expressed in many apt phrases, whilst of late years a new expression has come into being, whose meaning is "love of country". Its affinity to the dearest ties is seen in the word "fatherland", used by Greeks and Romans, Germans and French, in the phrase "mother country", used by the British, and in the phrase "one family" used by the Chinese.

The quality of love or affection for one's country has never been the predominant note in the Chinese conception of duty to the State. It is a conception which has come largely through the Chinese living abroad, being strangers in a strange land, and then returning to the home land. It is a quality which is spreading amongst the Chinese more and more, as they are able to take part in the affairs of govern- 
ment. That which brings into being this element of patriotism is the idea of democracy.

The typical characteristic of Chinese patriotism, a characteristic observed in all forms of patriotism, is loyalty. This applies not only to the official in his attitude to the head of the nation, be he President, King or Emperor, but to each individual in his relation to the Government. "Make loyalty and fidelity supreme" was the teaching of Confucius. Of late years the revolutionary spirit has meant love of country without loyalty to the Government or the Ruler. In the final outcome, it will be found that the only patriotism which can compete with the patriotism of people of other countries is that which has the stability of loyalty as well as the fervour of affection.

Another element of patriotism, whatever the people, is the willingness to render service, make sacrifices, and even to die, for the country. In times of peace, this means faithful performance of duty, with the laudable ambition to enhance the glory and prestige of one's country. If the Chinese have appeared lacking in this quality it is because they have had no part in government. In times of war, this spirit of self-sacrifice for the sake of the State may mean service on the battle-field. In the latter case there often arises the dilemma, as to whether the fighting is in defence of one's country or is for aggression and conquest. If it be the latter, then patriotism as a virtue is brought into comparison with some other virtue, which dominates all, such as devotion to Right and loyalty to Truth. Many a time in the history of nations have individual con- 
sciences, when allowed individual liberty, exhibited patriotism, heroism, and self-sacrifice of the highest type, in refusing to fight on the field of battle, and in daring to defend in the presence of cynicism and scorn the Higher Law of God.

"Once to every man and nation comes the moment to decide,

In the strife of Truth with Falsehood, for the good or evil side."

A distinguished American, William Everett, speaking at Harvard University in 1900, has used the strongest language in stating his conception of duty, and of patriotism as one form of duty. He said: "Granting war is sometimes necessary, if it is ever engaged in for any cause less than necessary, it is wrong; and the country is wrong that engages in it. If any country, your or mine, is in the wrong, it is our duty as patriots to say so, and not support the country we love in a wrong, because our countrymen have involved her in it. In the War of our Revolution, when Lord North had the King and virtually the country with him, Fox lamented that Howe had won the battle of Long Island, and wished he had lost it. What! an Englishman wish an English army to be defeated? Yes, because England was wrong; and Fox knew it and said so."

Thus we come to the point that one must indeed be always patriotic, in the sense of loving his country, but one is not of necessity compelled to favour war as against peace. To do one's duty, though in a minority, is often the truest patriotism.

Right here it is easy to turn our thoughts from 
nationalism to consider internationalism and from patriotism to the idea of universal brotherhood, for it will be seen that they both unite in devotion to truth and a Higher Law.

Fraternity is a conception which had its birth far back amongst all civilized peoples, but Internationalism is a new word and a new idea. It represents co-operation on a universal scale. It recognizes competition the world round. It is one form of universal peace, not by eliminating national distinctions, but by adjusting relations between one nation and another. Internationalism is the practical embodiment of an ideal conception of human brotherhood. It recognizes the unity of the race, as it came from the heart of God, and as the goal towards which the world moves. Above is the one God and Father of all, and below are brother men. Humanity is one family. The Chinese have two sayings: "All under heaven are one family" and "Within the four Seas all are brothers." There are ties of affection, of culture, of commerce, of postal communication, of telegraphy, of religious sentiment, of humanitarian aspiration, and of social intercourse, which bind men together in utter disregard of mere national demands. The globe has grown smaller, and earth's inhabitants draw nearer and nearer to each other. Men of one country learn from those of another, and our personal friends include all climes and all nations. The one who travels much is cosmopolitan, and the cosmopolitan spirit exhilarates, just as the insular spirit dries up the sympathies and deadens even religion. To live abroad and mingle with other people liberalizes, and makes living 
a joy. When in 1900 a little company of many nations were besieged in Peking, they took pleasure in breaking up into different groups, each group singing its own national anthem.

To be at peace with each other is to set into action the international mind. To be at war puts a cleavage deep down into this globe of ours, and sometimes right up into the heavens.

Out here in the Far East we have had in mind for years something of the same kind of international co-operation, first in an Institute of learning, and then in a Museum and Library. Just for the moment, the international idea is under a cloud and is subject to scorn. War has over-shadowed everything.

At heart all men, with any religious sentiment whatever, are opposed to war. The excuse for war is that it is one of defence; sometimes it is said, that it is for humanity's sake. Such impressions make it easier to fight "in all good conscience". The international mind is only held in abeyance; it is not completely destroyed by the havoc of the battle-field. It even occurs that warriors become so sickened of shot and shell, of shrapnel and bombs, of wounds and bloodshed, that the end of the war is eagerly awaited, and enemies quickly become friends. The warrior is after all international in his inner impulse.

Sometimes the patriot retains his international feelings by refusing to join in war, or at least by deeply regretting the necessity of war.

The call of duty, the mandate of the Higher Law, making the patriot to stand aside, when his coun- 
try goes to war, is none the less a patriot. The man of true international feelings cannot but pray for the overthrow of war and all its accompanying evils, and for the reign of peace and justice.

Thus both patriotism and internationalism draw near to each other, as they bow to the supremacy of God's way, that of peace and righteousness. As they bow before the highest and the best, they clasp hands and vow to defend the other. The spirit of nationalism and the spirit of internationalism are not mutually antagonistic, but mutually helpful.

Nationalism represents independence, and independence is essential to national sovereignty. Internationalism represents inter-dependence, and this is essential to human brotherhood.

There have been those who have proposed some kind of international congress, that internationalism may have more than an academic value, and that war may be averted. This means more than an international Court of Justice, and much more than an international Court of Arbitration, both of which will be the fruits of the Hague Peace Conferences. In time the idea of various national representatives deciding questions of common interest will no doubt grow, without in any way infringing on the rights of nationality. As bearing on this matter the words of Dr. Trueblood, secretary of the American Peace Society, may be quoted: "National sovereignty and independence are not absolute, and in the very nature of the case cannot be. The nations are members of 'the family of nations', and the governments are compelled, in various important matters of common concern, to take counsel of one another, or, in 
other words, to exercise a joint sovereignty which is beyond the field of national sovereignty, and which no nation can exercise alone."

There is too often a misconception, that to have the international mind is to work against one's own country and to be ashamed of one's own people. In commercial matters, especially, international competition, or rather competition between two or three nations, has become so intense that the destruction of the trade of some other country, and hostility to the people of that country, denotes high patriotism. The end is war, with the collapse of trade, of both friend and foe. The international mind has no need of war, and recognizes that the prosperity of other countries does not mean the downfall of one's own country. Professor Lecky, in his "Rationalism in Europe", has said: "The conceptions that the interests of adjoining nations are diametrically opposed, that wealth can only be gained by displacement, and that conquest is therefore the chief path to progress, were long universal; but during the last century political economy has been steadily subverting them, and the time will come when a policy of territorial aggrandizement will be impossible."

The failure to recognize this possibility and desirability of international co-operation has, to my mind, been the primal cause of the present disastrous war in Europe, embracing five continents. If blame is to be given, or if any country is to be declared innocent, blame and innocence may alike be extended to all. By each overstepping the mark just a little, and through lack of confidence in the 
compatibility of internationalism with nationalism, the cataclysm has come.

It is indeed true that all peace efforts have failed to ward off this last great war of Europe, which many have for years feared was coming, and it is also true that peace arguments are treated with derision, and that pacifists are more than ever treated as foolish dreamers. When the war is over and millions bear burdens never borne before, then once again there will spring in the breast a desire for peace between all nations and all governments will proceed with new vigour to plan the prevention of war.

Genius is needed as much in devising peace measures as in military strategy. Courage, too, is as much a necessity in the peaceful employments of trade as on the battle-field. Heroism will not die out, when war has died away. A college-bred man fighting in the Cuban war truly said: "It was much easier for me to face Spanish bullets in one exciting charge than to face a bribe of $\$ 10,000$ a year to give my knowledge of law to a nefarious enterprise."

Through the study of the measures of international peace which has been given by men of science, especially the science of jurisprudence, the cause of peace has been lifted above the basis of mere goodfeeling, however important and agreeable good-feeling always is, up to the basis of clear, untarnished righteousness. Only by learning to deal with each other fairly, to consider questions in a judicial temper and so in a brave spirit, can we learn to be at peace with each other, and be true friends to each other. National bias must give place to interna- 
tional justice. Without this there will certainly be mutual bickerings and contemptuous accusations liable to flare up into the blaze of actual war. The Bible was first pure and then peaceable." Dr. Lyman Abbott has said truthfully: "Enduring peace is possible only when it is the peace of justice. The blow of the fist, gleam of the sword, and the roar of the cannon, will continue until some other power than that of the armed man is found to protect innocence from injustice. With the convening of The Hague Conference in 1899 there was wrought into the consciousness of mankind a better plan than war for establishing justice between the nations." This quality of justice, daring to do right and be right, is no namby-pamby kind of thing as peacefulness is misrepresented as being. Peace when solidified in justice is as sterling a quality as the martial spirit that looks for blood and shrinks not from it.

The benefits of this exalted cause that seeks to bind nations together in true fraternity, are beyond compute. The horrors, the calamity, the folly, the madness, of the present war in Europe, which the cause of peace and justice and all The Hague Conferences have been powerless to check, are also beyond compute. When General Grant was offered a military review by the Duke of Cambridge, he declined, saying: "I do not wish to look on another regiment of soldiers." It was Wellington who wrote, "If you had seen but one day of war, you would pray God you might never see another." Perhaps the supreme horror of the present war will be the means, 
and the only means, of self-defence along paths of peace.

This international peace idea and the progress made are very largely due to the new spirit brought into the world by Christ, and to the fundamental principles which he taught to his disciples. As to the attitude of Christ on this matter there is no dispute. The early Christians for the first two centuries showed the same spirit, and in nearly every case refused to enter the army of the Roman Empire. From these early days down to the present this spirit of Christ has been in constant conflict with the militant spirit of powerful nations. Christ has stood for peace; the Church too often has stood for war. John Ruskin has said, "The Christianity which we have been taught for 2,000 years is still so little conceived by us, that we suppose the laws of charity and self-sacrifice bear upon individuals in all their social relations, and yet do not bear upon nations in their political relations." And so Whittier, in an unusual tone of irony, sings:

"Rosy and sleek, the sable-gowned divine, O'er his third bottle of suggestive wine, To plumed and sworded auditors shall prove, Their trade accordant with the law of Love, And Church for State, and State for Church, shall fight,

And both agree that Might alone is Right."

Whilst the war still rages, and human lives are still offered on the altar of what each believes to be the truth, and misery increases from day to day, it is well for us to heed the appeal of the Supreme 
Pontiff that the clash of arms give place to kindly greeting from friend to friend and brother to brother. Each nation must have its equal chance in the industrial, commercial and financial contests of the whole world, and the genius and scholarship of one must supplement the attainments of others. Seeking to exclude any nation or any race, from world-wide pursuits, or in planning to overstep the boundaries of other nations and to occupy their terrritory, may be called patriotism, though of a very poor type, but it cannot be called internationalism, still less Christian brotherhood. When the complicated problems of the nations now at war are finally settled, it is to be hoped that the boundaries of each nation as then determined will henceforth be regarded as sacred, and no people need fear attack from any other. Politically all nations are to be satisfied with their own, and not to covet the property or territory of each other; they are to limit themselves to their own. In all other respects-in commerce, industry, education, religion, travel and social enjoyments on land and on sea-the whole world is to be the free channel for each and all; there are to be no limits. By thus discriminating the self-imposed limitations of national sovereignty, and the boundless scope for every individual, can internationalism become a working theory.

The British Prime Minister, Mr. Asquith, some months ago gave utterance to some excellent advice as to the mutual obligations of great and small nations. Though possibly his expressions imply guilt on the part of some and innocence on the part of England, yet the main idea of this distinguished 
statesman must win the assent of all who think seriously of problems which are universal in their meaning and operation. I quote his words:

"Forty-four years ago, at the time of the war of $1870, \mathrm{Mr}$. Gladstone used these words. He said, 'The greatest triumph of our time will be the enthronement of the idea of public right as the governing idea of European politics.' Nearly fifty years have passed. Little progress, it seems, has yet been made toward that good and beneficent change, but it seems to me to be now, at this moment, as good a definition as we can have of our European policy.

"Belgium, Holland, and Switzerland, the Scandinavian countries, Greece, and the Balkan States,they must be recognized as having exactly as good a title as their more powerful neighbours,-more powerful in strength as in wealth,-exactly as good a title to a place in the sun. And it means, finally, or it ought to mean, perhaps by a slow and gradual process, the substitution for force, for the clash of competing ambitions, for groupings and alliances and a precarious equipoise, the substitution for all these things of a real European partnership, based on the recognition of equal right and enforced by a common will. A year ago that would have sounded like a Utopian idea. It is probably one that may not or will not be realized either today or tomorrow."

It is, too, our hope that this high ideal will be realized, and that the nations of Asia as well as of Europe and America will come into the full possession of these rights, inalienable and unalterable.

Nationalism and internationalism are both in harmony with the religious sentiment. We have only 
time to cite the teaching of Christianity. The Apostle Paul, preaching on Mars' Hill in Athens to Greek philosophers, enunciated this statement, to which the Confucianist can well subscribe: "God hath made of one blood all nations of men, for to dwell on the face of the earth, and hath determined the times before appointed, and the bounds of their habitation.' Here there are two legitimate conditions under which humanity is placed, the condition of worldwide brotherhood, and the condition of national limitations, determined by God, and of national obligation to self-defence, likewise from God's will. If one nation is to be content with its own God-given inheritance, without encroaching on the territory or crossing the borders of another, so also is it obliged to defend its own against aggression from another. National territory does not necessitate mere national trade. To territory there may be national limits, but to trade, enterprise, and intercourse there need be no limitation, they are international or universal. A small country may rank first in commerce. Territorial aggrandizement or wars of conquest are needless as well as wrong. This is common sense, and this is Christianity.

It is Religion, rather than some particular religion, which sympathizes with and encourages the spirit and the policies of international brotherhood. Some of the great Religions, in their zeal for propagating their special tenets and ceremonies, have been more divisive than harmonious, and have penetrated even national sentiments with their divisive spirit. Other religions have been promulgated as local or national Faiths, adapted to limited condi- 
tions. Lacking the universal outlook, they have thought but little of the important relations which exist between nation and nation and their respective governments. Whatever may be said of the failings of Christians and of different branches of the Christian Church, the true student of history must acknowledge that Christ and his first followers took a broad look over the world, recognized the place of governments and rulers, and the fact of national distinctions, and, with them, enjoined the duty of world-wide fellowship, which leaps the bounds of race or State. They pointed on to coming ages, when war between nations will cease, and all kings and nations will bow to the will of a Universal Will, to the law of love as centered in the Supreme, and embodied and made known in Jesus Christ, whose inspiration will fill all things. Jesus is the universal Brother, God is the universal Father, and through them there will yet come international brotherhood and peace amongst all men. 






\section{Date Due}

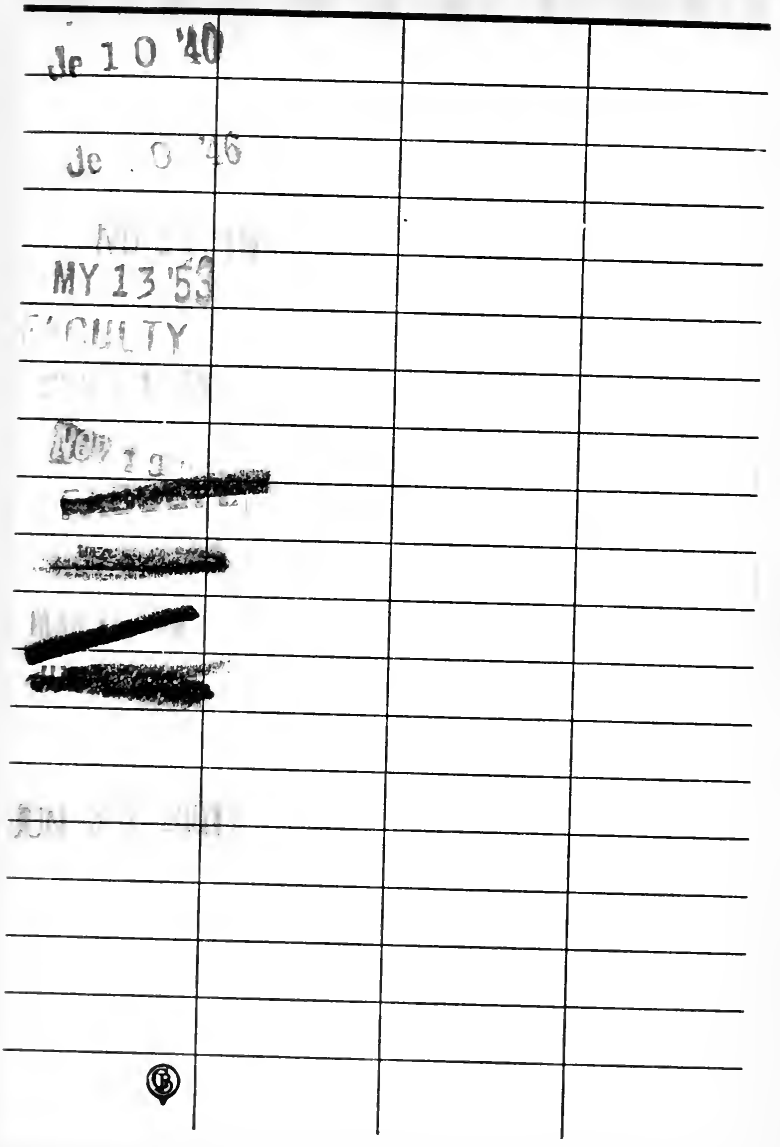



BL80.R35

A Christian's appreciation of other

Princeton Theological Semınary-Speer Library 